DOMINGOS CARLOS ODDONE

COGERAÇÃO:

\title{
UMA ALTERNATIVA PARA PRODUÇÃO DE
}

\section{ELETRICIDADE}

\author{
Dissertação apresentada ao Programa \\ Interunidades de Pós Graduação em \\ Energia da Universidade de São Paulo - \\ Escola Politécnica, Faculdade de \\ Economia e Administração, Instituto de \\ Física e Instituto de Eletrotécnica e \\ Energia para obtenção do titulo de Mestre \\ em Energia.
}

Orientador: Prof. Dr. Murilo Tadeu Werneck Fagá

São Paulo

2001 
A G R A D E C I MENTOS

Ao amigo e orientador Prof. Dr. Murilo Tadeu Werneck Fagá, que além das valorosas orientações, sempre me deu grande incentivo para a conclusão deste trabalho.

Aos meus familiares, que compreenderam as inúmeras horas, nos finais de semana, e nas noites que me dediquei a este trabalho.

A todos amigos e companheiros de jornada que colaboraram direta ou indiretamente na realização deste trabalho. 


\section{S U M A R I O}

\section{Lista de tabelas}

Tabela 1 Oferta interna de energia 04

Tabela 2 Consumo final de energia por fonte 04

Tabela 3 Composição e evolução da oferta de eletricidade 04

Tabela 4 Perspectivas para autoprodução 06

Tabela 5 Consumo de energia no setor industrial por energético 07

Tabela 6 Setores industriais com potencial de cogeração 08

Tabela 7 Energéticos consumidos nos setores industriais 09

Tabela 8 Eficiências de sistemas de cogeração 24

Tabela 9 Dados das instalações 25

Tabela 10 Emissão de gases para turbinas de grande porte 27

Tabela 11 Emissão de gases para os dois processos 27

Tabela 12 Tarifas do gás natural 35

Tabela 13 Tarifas do gás natural 36

Tabela 14 Tarifas do gás natural 37

Tabela 15 Tarifas de eletricidade 39

Tabela 16 Preços de Caldeiras - Combustíveis Líquidos/Gasosos 40

Tabela 17 Preços de Equipamentos para Reforma de Caldeira 41

Tabela 18 Preços de Turbinas a Vapor 41

Tabela 19 Preços de Turbinas a Gás 41

Tabela 20 Preços de Absorvedores 42 


\section{Lista de figuras}

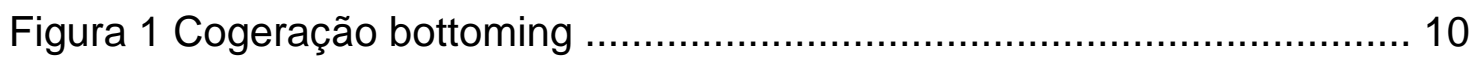

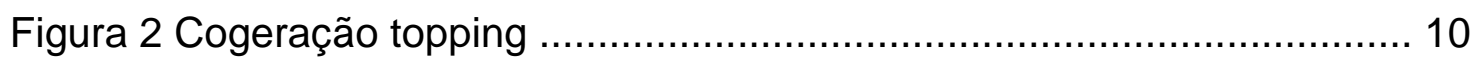

Figura 3 Esquema de ciclo de cogeração com motor ................................... 11

Figura 4 Esquema de cogeração ciclo Rankine ............................................ 12

Figura 5 Cogeração com ciclo Brayton aproveitando o calor ........................... 13

Figura 6 Cogeração com ciclo Brayton ....................................................... 14

Figura 7 Esquema de cogeração com ciclo combinado ............................... 16

Figura 8 Esquema de operação de uma instalação de ciclo combinado ......... 17

Figura 9 Esquema de um ciclo de motor de combustão (Diesel) .................... 17

Figura 10 Esquema de um ciclo de motor de combustão (Otto) ..................... 18

Figura 11 Esquema de turbinas a vapor ....................................................... 18

Figura 12 Esquema de cogeração com ciclo de absorção ............................ 22

Figura 13 Esquema de operação do ciclo de absorção .................................. 23

Figura 14 Evaporador de equipamento de absorção .................................... 24

Figura 15 Exemplo de planilha de calculo .................................................... 46

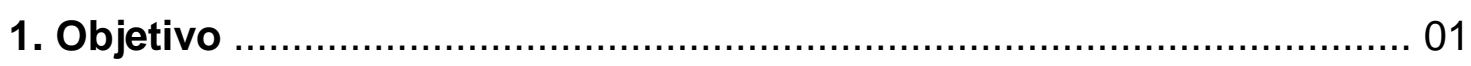

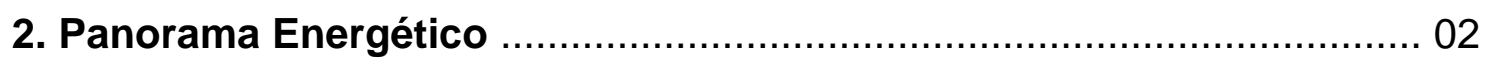

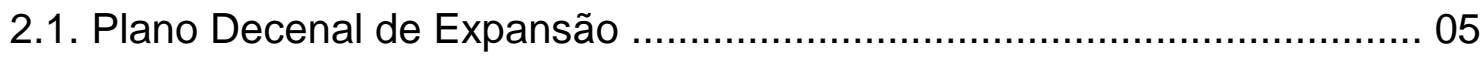

2.2. Setores de Atividade com Potencial de Cogeração .................................. 08

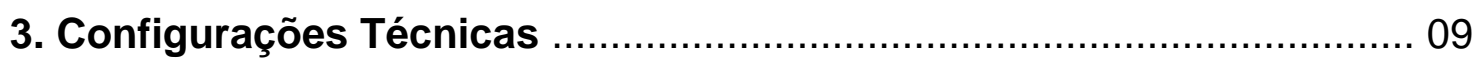

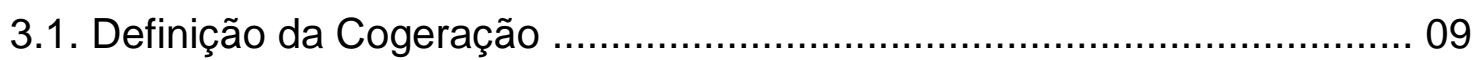

3.2. Tipos de Cogeração ...................................................................... 10 
3.3. Ciclos Termodinâmicos 11

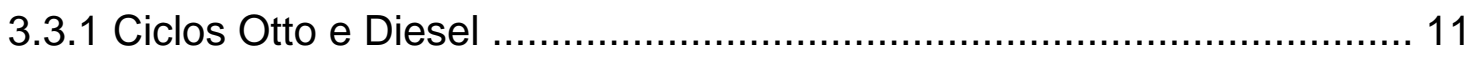

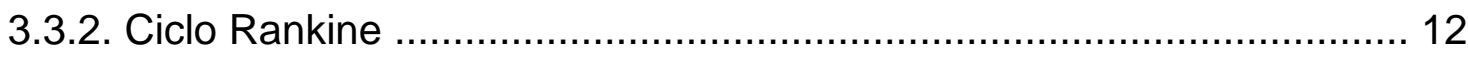

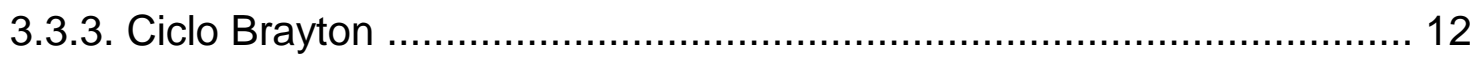

3.3.4. Ciclo Combinado ...................................................................... 15

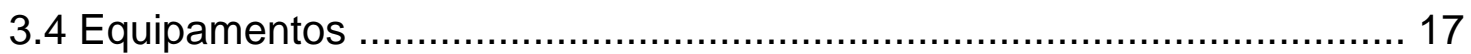

3.4.1. Motores Alternativos de Combustão Interna .................................. 17

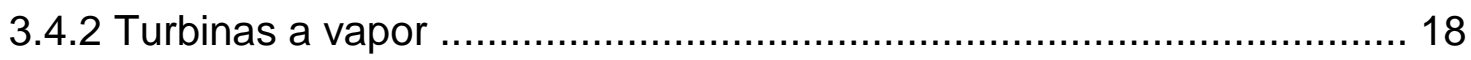

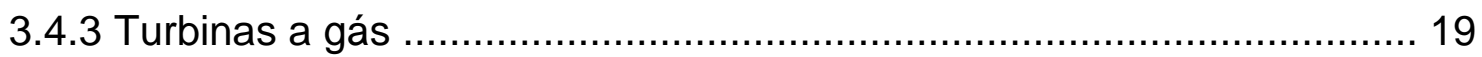

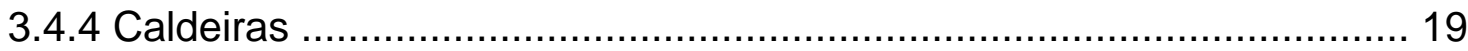

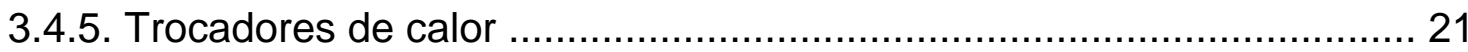

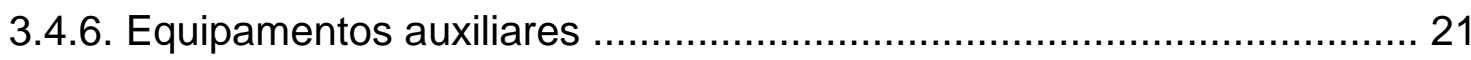

3.4.7 Equipamentos de conversão de energia mecânica em elétrica ............. 21

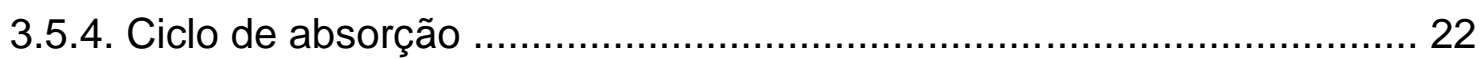

3.5.1. Equipamentos de absorção ........................................................ 23

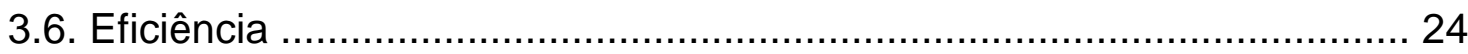

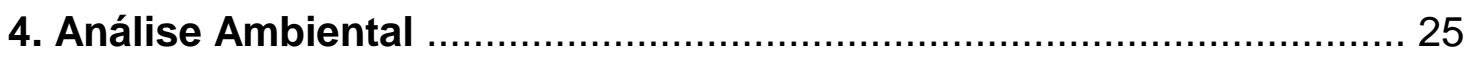

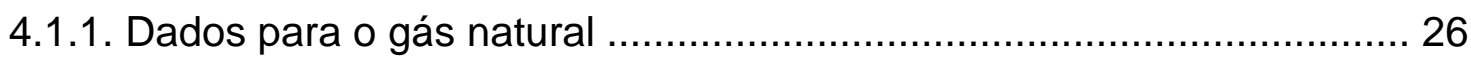

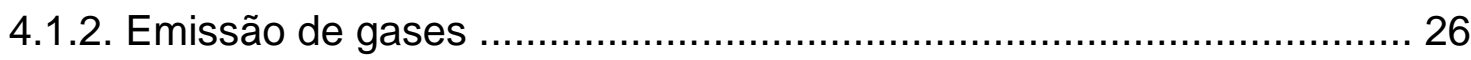

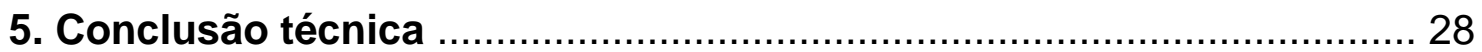

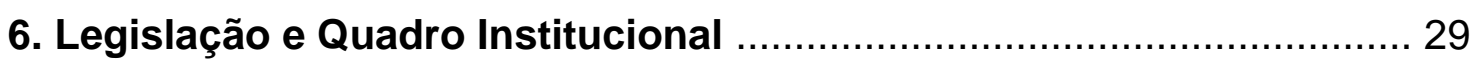

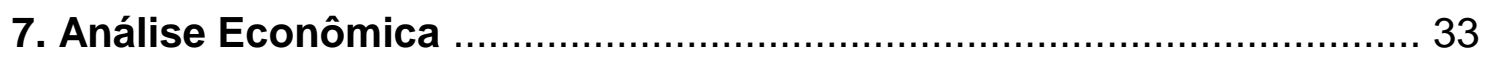

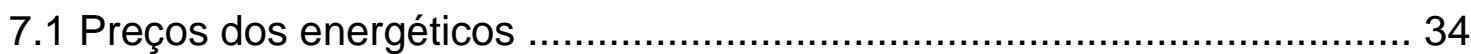

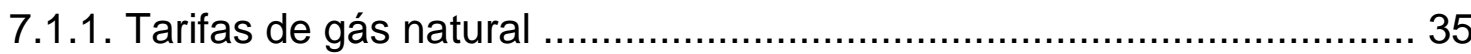




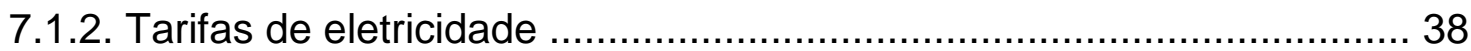

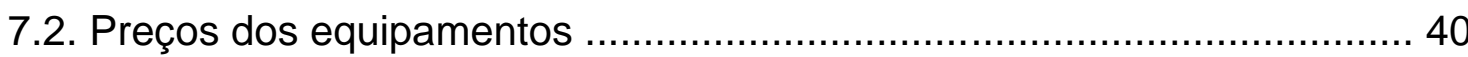

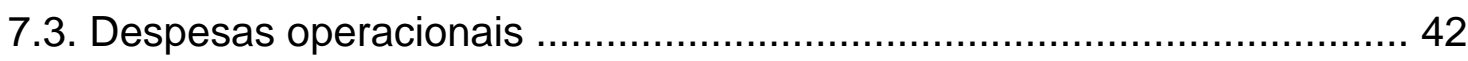

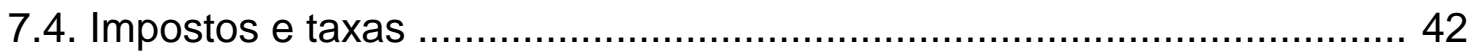

7.5. Análise econômica e financeira ......................................................... 43

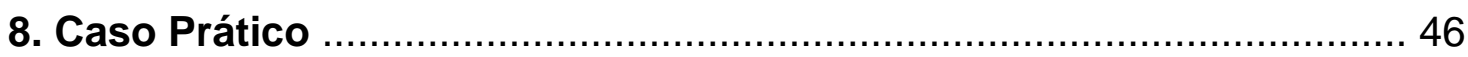

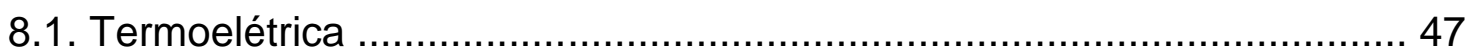

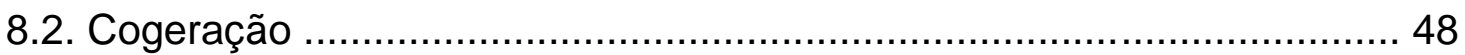

8.2.1. Cogeração com eletricidade excedente ......................................... 50

8.2.2. Cogeração sem eletricidade excedente ........................................ 61

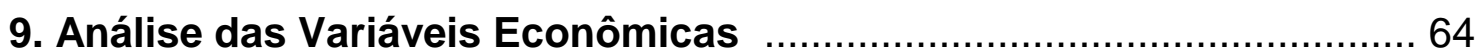

9.1. Sensibilidade ás tarifas de energia ......................................... 64

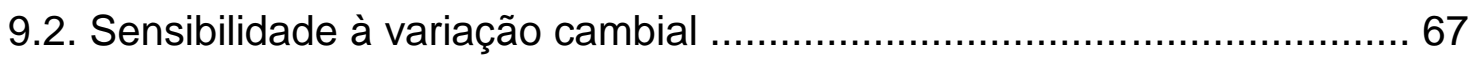

9.3. Sensibilidade às taxas de juros ........................................................ 70

9.4. Somatória de efeitos .................................................................. 73

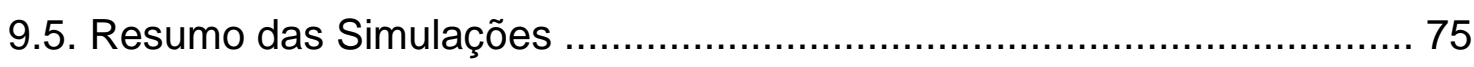

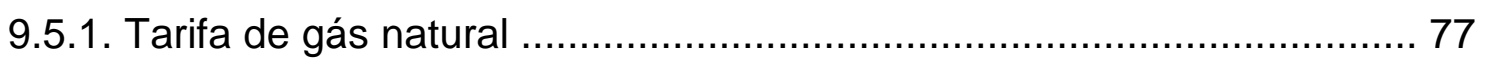

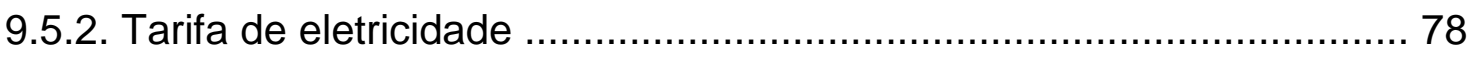

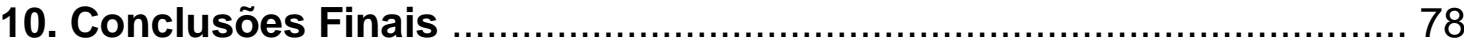

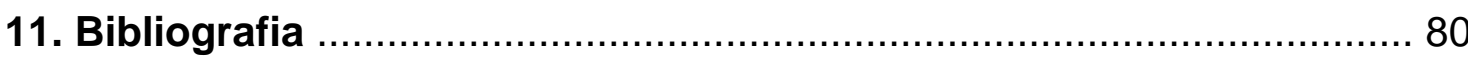




\section{Objetivo}

O objetivo deste trabalho é demonstrar por que a cogeração não se desenvolve no Brasil, mesmo apresentando-se como alternativa para produção de eletricidade.

Entretanto existem vários estímulos por parte do Estado para a implantação de grandes termoelétricas no país.

Será apresentada a análise dos processos de cogeração, envolvendo: as alternativas tecnológicas, a viabilidade econômica, e as questões ambientais, chegando-se a um quadro indicando a sensibilidade aos diversos parâmetros econômicos que fazem parte dos projetos de cogeração.

Serão mostrados cenários com a visão de futuro, indicando diferentes opções que permitam o crescimento do mercado de energia no Brasil, de uma forma mais segura.

No momento em que o Brasil passa por profundas mudanças no setor energético, incluindo a necessidade da expansão do parque gerador e considerando que parte importante dessa expansão será através de grandes centrais termoelétricas, torna-se importante apresentar uma alternativa de produção de eletricidade, no Brasil ainda pouco explorada, que é a cogeração.

Este trabalho irá mostrar que com maior incentivo aos projetos de cogeração, através de uma política energética nacional adequada, se pode produzir parcela importante da energia elétrica para 0 atendimento das necessidades crescentes da sociedade brasileira, com menor impacto ambiental e econômico, refletindo em menor custo final da energia produzida. 


\section{Panorama Energético}

O Brasil tem apresentado uma demanda de energia elétrica crescente nas últimas décadas, tornando necessários grandes investimentos para aumentar a capacidade instalada.

O crescimento do consumo de energia elétrica no Brasil apresenta uma relação direta com os momentos econômicos que o país atravessa, esse fenômeno é diferente do que ocorre em países já desenvolvidos, que apresentaram crescimento econômico acompanhado de decréscimo no consumo de energia, justificados por medidas de racionalização no uso e adoção de tecnologias mais eficientes que proporcionam o mesmo efeito final da aplicação de energia com menor consumo relativo. Entretanto no Brasil onde o consumo per capta é ainda muito abaixo dos índices de conforto mínimo da população, fica visível que qualquer movimento favorável da economia traz aumentos significativos do consumo de energia. Esse fenômeno pode ser observado recentemente com o advento do "Plano Real", que apesar de apresentar nos primeiros anos um movimento de recessão no consumo industrial, o consumo de eletricidade na classe residencial superou as reduções apresentadas pelas indústrias, dando como resultado aumentos positivos no consumo global de eletricidade. A classe residencial que representava $22 \%$ passou a representar $27 \%$ do consumo total de energia na matriz energética. Esse aumento na classe residencial foi justificado pelo 
aumento nas vendas de eletrodomésticos, que as classes menos favorecidas não tinham acesso antes do plano econômico.

O crescimento do consumo de eletricidade foi de $6 \%, 6,5 \%, 4,2 \%$, e 2,5\% nos anos de 1997 a 1999, respectivamente. Em termos globais, o crescimento do PIB de 1996 a 1999 foi de $7,7 \%$ e o consumo de energia elétrica foi de $18,8 \%{ }^{\left[{ }^{[1]}\right.}$

A produção de energia elétrica no Brasil é predominantemente de origem hidráulica, intensiva em investimentos de capital, e a sua expansão foi até hoje, suportada pelo Setor Público, que esgotou sua capacidade de investimento na geração elétrica.

Os investimentos, por sua vez, têm sofrido um considerável impulso na história recente de nosso país, notadamente pela política de privatizações de empresas do setor energético brasileiro, indicando que o Estado deixaria de ser empresário e passaria a exercer as funções de agente regulador, e formulador de políticas públicas na área de energia, cabendo agora os novos investimentos ao setor privado.

O esgotamento dos grandes potenciais hidráulicos economicamente aproveitáveis e próximos aos grandes centros consumidores, as crescentes exigências ambientais e a competição oferecida por outras alternativas de geração deverão estabelecer outro equilíbrio no mercado de produção e venda de energia.

Razões econômicas, ambientais e de sistema viabilizam em um curto espaço de tempo, o uso de outras fontes energéticas e a implantação de 
métodos e procedimentos de racionalização da produção e uso eficiente da energia.

As tabelas $n^{\circ} 1$ e 2, a seguir, apresentam a evolução da oferta interna (Brasil) e do consumo de alguns energéticos. Nessa tabela foram selecionados aqueles energéticos que são utilizados em sistemas de geração termoelétrica e de cogeração, alem da própria energia elétrica. [1]

\begin{tabular}{|l|l|l|l|l|l|l|l|l|l|l|}
\hline \multicolumn{1}{|c|}{ UONTES } & $\mathbf{1 9 9 0}$ & $\mathbf{1 9 9 1}$ & $\mathbf{1 9 9 2}$ & $\mathbf{1 9 9 3}$ & $\mathbf{1 9 9 4}$ & $\mathbf{1 9 9 5}$ & $\mathbf{1 9 9 6}$ & $\mathbf{1 9 9 7}$ & $\mathbf{1 9 9 8}$ & $\mathbf{1 9 9 9}$ \\
\hline Petróleo e Derivados & 56614 & 58004 & 59718 & 61827 & 65387 & 69032 & 75998 & 80692 & 84618 & 85661 \\
\hline Gás Natural & 4230 & 4248 & 4483 & 4805 & 5000 & 5289 & 5798 & 6336 & 6645 & 7568 \\
\hline Lenha e Carvão Vegetal & 28180 & 26367 & 24476 & 24483 & 24544 & 22975 & 21397 & 24522 & 20999 & 21265 \\
\hline Cana de Açúcar e Derivados & 18459 & 19378 & 19378 & 19793 & 19653 & 22080 & 22225 & 23272 & 24645 & 24601 \\
\hline Eletricidade & 67641 & 71010 & 71733 & 76158 & 79596 & 83884 & 87675 & 92638 & 95953 & 96493 \\
\hline
\end{tabular}

Tabela no 1 Oferta interna de energia (10^3 tep)

Fonte: Balanço Energético Nacional 2000

A tabela n 3 mostra a composição da oferta de eletricidade, produzida através da energia hidráulica, térmica e nuclear. ${ }^{[4]}$

Potência Instalada (MW)

\begin{tabular}{|l|l|l|l|l|l|l|l|l|l|l|}
\hline FONTES & $\mathbf{1 9 9 0}$ & $\mathbf{1 9 9 1}$ & $\mathbf{1 9 9 2}$ & $\mathbf{1 9 9 3}$ & $\mathbf{1 9 9 4}$ & $\mathbf{1 9 9 5}$ & $\mathbf{1 9 9 6}$ & $\mathbf{1 9 9 7}$ & $\mathbf{1 9 9 8}$ & $\mathbf{1 9 9 9}$ \\
\hline Petróleo e Derivados & 55728 & 56246 & 57781 & 59948 & 63217 & 67512 & 72393 & 78053 & 81128 & 81100 \\
\hline Gás Natural & 3015 & 3028 & 3213 & 3540 & 3660 & 3829 & 4422 & 4803 & 4965 & 5488 \\
\hline Lenha e Carvão Vegetal & 21428 & 20453 & 19307 & 18757 & 18795 & 17677 & 17177 & 17031 & 17019 & 17374 \\
\hline Cana de Açúcar e Derivados & 17238 & 18155 & 18706 & 18762 & 21272 & 21364 & 22193 & 23608 & 23573 & 23596 \\
\hline Eletricidade & 63121 & 65358 & 66837 & 69938 & 72440 & 76793 & 80529 & 85460 & 89039 & 91262 \\
\hline
\end{tabular}

Tabela no 2 Consumo final de energia por fonte (10^3 tep)

Fonte: Balanço Energético Nacional 2000

\begin{tabular}{|c|r|r|r|r|}
\hline ANOS & HIDRO & TERMO & NÚCLEAR & TOTAIS \\
\hline 1999 & 51424 & 3478 & 657 & 55559 \\
\hline 2000 & 52313 & 5612 & 1966 & 59891 \\
\hline 2001 & 53993 & 5647 & 1966 & 61606 \\
\hline 2002 & 56124 & 7827 & 1966 & 65917 \\
\hline 2003 & 60491 & 8517 & 1966 & 70974 \\
\hline 2004 & 62698 & 8517 & 1966 & 73181 \\
\hline
\end{tabular}

Tabela no 3 Composição e evolução da oferta de eletricidade

Fonte: Plano ONS 2000 


\subsection{Plano decenal de expansão 1999/2008}

Atualmente, cerca de $20 \%$ da demanda por energia elétrica dos setores de alumínio, siderurgia, papel e celulose, ferroligas, soda-cloro, cimento e petroquímica é atendida através de autoprodução. ${ }^{[3]}$ As perspectivas de expansão da economia e as mudanças institucionais em curso no Setor Elétrico deveriam configurar um quadro de estímulo ao aumento dessa autoprodução. Nesse sentido, um grande número de projetos tem despertado o interesse dos consumidores que têm realizado diversos estudos para implantação de empreendimentos de geração de energia elétrica, mas que a maioria deles não passa dos estudos.

É necessária a introdução de uma legislação mais flexível e com regras mais claras, associadas a fatores de relevância macroeconômica, que criariam condições mais propícias para a ampliação da autoprodução no Brasil.

Dentre estes fatores, destacam-se:

- a busca constante por maior eficiência e por menor custo de produção, no intuito de obter melhores condições de competitividade;

- a expectativa de recuperação do nível tarifário no suprimento de energia elétrica (vendas em grosso), com reflexos, principalmente, sobre o grupo de consumidores atendidos em alta tensão;

- a flexibilização da legislação sobre autoprodução e das regras que definem as atividades da indústria de eletricidade; 
- a maior penetração de outros energéticos, especialmente do gás natural, aumentando a potencialidade da cogeração.

Neste novo cenário, indústrias que até então se colocavam apenas como consumidores de energia ou que atuavam modestamente na atividade de geração própria de energia elétrica, poderia manifestar a intenção de investir em empreendimentos para autoprodução.

O plano decenal; de expansão da Eletrobrás de 1999/2008, considerou os fatores acima apontados como já realizados e construiu um único cenário de autoprodução (otimista) resumido na Tabela ํo $4 .{ }^{[3]}$

\begin{tabular}{|l|l|l|}
\hline ANO & 2003 & 2008 \\
\hline Energia autoproduzida TWh & 36,7 & 45,8 \\
\hline
\end{tabular}

Tabela 4 - Perspectivas para Autoprodução

Fonte: Plano decenal de expansão da Eletrobrás

A tabela $n^{0} 5$, a seguir, mostra a projeção do consumo de energia no setor industrial até 2010 , sendo considerado um cenário otimista. ${ }^{[3]}$ 
Tabela n5 - CONSUMO DE ENERGIA NO SETOR INDUSTRIAL POR ENERGÉTICO - $10^{\star} 9 \mathrm{kcal}$

(Cenário Otimista)

Fonte: Plano decenal de expansão - Eletrobrás

\begin{tabular}{|c|c|c|c|c|c|c|c|c|c|c|c|c|c|c|c|c|c|c|}
\hline Ano & $\begin{array}{c}\text { Gás } \\
\text { Natural }\end{array}$ & $\begin{array}{c}\text { Carvão } \\
\text { Veg. }\end{array}$ & Lenha & $\begin{array}{c}\text { Outras } \\
\text { Prim. }\end{array}$ & Diesel & $\begin{array}{c}\text { Óleo } \\
\text { Comb. }\end{array}$ & $G L P$ & Nafta & Queros. & $\begin{array}{l}\text { Gás } \\
\text { Canal. }\end{array}$ & $\begin{array}{c}\text { Gás } \\
\text { Refin. }\end{array}$ & $\begin{array}{c}\text { Gás } \\
\text { Coqu } \\
e\end{array}$ & $\begin{array}{c}\text { Coqu } \\
e \\
\text { C.Min. }\end{array}$ & Eletric. & $\begin{array}{c}\text { Carvão } \\
\text { Veg. }\end{array}$ & Bagaço & $\begin{array}{c}\text { Outras. } \\
\text { Sec }\end{array}$ & Total \\
\hline 1985 & & 2.432 & 9.750 & 2.812 & 529 & 23.879 & 871 & 2.445 & 450 & 642 & 368 & 2.231 & 10.095 & 31.676 & 2.651 & 17743 & 3847 & 112421 \\
\hline 1986 & & 2.832 & 10.083 & 3.5 & 597 & 26.436 & 925 & 2.158 & 614 & 744 & 858 & 2.204 & 8.611 & 33.329 & 2.796 & 18779 & 2865 & 117359 \\
\hline 1987 & & 2.576 & 9.902 & 3.590 & 649 & 28.849 & 1.035 & 2.224 & 631 & 808 & 1.052 & 2.165 & 8.680 & 33.398 & 3.017 & 19100 & 3908 & 121584 \\
\hline 1988 & & 2.728 & 9.086 & 3.719 & 693 & 27.915 & 945 & 2.423 & 687 & 864 & 277 & 2.455 & 11.040 & 35.491 & 2.720 & 21005 & 4086 & 126134 \\
\hline 1989 & 860 & 1.780 & 8.566 & 3.788 & 719 & 09 & 956 & 143 & 56 & 642 & 187 & .389 & 12.406 & 36.126 & .914 & 173 & 112 & 026 \\
\hline 1990 & 1.923 & 1.548 & 8.073 & 3.589 & 701 & 28.229 & 987 & 2.055 & 703 & 422 & 245 & 2.310 & 12.041 & 34.748 & 1.678 & 18290 & 4041 & 121583 \\
\hline 1991 & 2.255 & 2.564 & 7.479 & 3.874 & 1.543 & 27.142 & 1.175 & 2.040 & 571 & 356 & 155 & 2.306 & 12.903 & 35.036 & 938 & 941 & 4245 & 128523 \\
\hline 1992 & 2.952 & 16 & & 4.075 & 1.577 & 27.780 & 1.327 & 1.856 & 482 & 300 & 116 & 332 & 12.792 & 34.654 & 03 & & 572 & 523 \\
\hline 1993 & 3.731 & 984 & 6.704 & 4.801 & 1.879 & 28.783 & 1.534 & 2.202 & 466 & 144 & & 2.424 & 12.441 & 36.520 & 525 & 29270 & 4068 & 136476 \\
\hline 1994 & 5.191 & 800 & 5.950 & 5.245 & 1.924 & 29.288 & 1.838 & 2.136 & 383 & 5 & & 2.262 & 14.110 & 37.670 & 397 & 33324 & 4493 & 145062 \\
\hline 1995 & 6.790 & 1.032 & 5.723 & 5 & 2.002 & 28.897 & 2.111 & 2.232 & 408 & 21 & & 2.310 & 027 & 37 & 386 & 89 & 25 & 667 \\
\hline 1996 & & 1.080 & 5.277 & 6.111 & 2.036 & & 2.471 & 1.458 & 180 & 4 & & 2.411 & 917 & & 50 & 39766 & 554 & 809 \\
\hline 1997 & 8.929 & 1.116 & 5.036 & 6.421 & 2.321 & 32.007 & 3.383 & 847 & 180 & - & & 2.455 & 13.083 & 38.532 & 321 & 43642 & 4864 & 163137 \\
\hline 1998 & 8.556 & 1.080 & 4.935 & 5.998 & 3.267 & 31.824 & 3.586 & 737 & 178 & - & 323 & 2.464 & 13.241 & 38.184 & 224 & 59669 & 5288 & 179554 \\
\hline 1999 & 9.232 & 1.066 & & 5.968 & 3.428 & 31.666 & 3.733 & 706 & 164 & - & 313 & 2.440 & 12.855 & 37.399 & 225 & 60051 & 5309 & 179474 \\
\hline 2000 & 10.791 & 1.055 & 4.915 & 5.953 & 3.506 & 31.865 & 3.865 & 709 & 163 & - & 297 & 2.453 & 13.161 & 39.135 & 226 & 61152 & 5345 & 184593 \\
\hline 2001 & 12.494 & 1.082 & 5.091 & 6.156 & 3.486 & 32.939 & 3.956 & 720 & 167 & - & 304 & 2.560 & 13.542 & 41.001 & 236 & 117 & 5577 & 192430 \\
\hline 2002 & 14.270 & 1.109 & 5.271 & 6.361 & 3.436 & 34.082 & & 732 & & - & 312 & 671 & 14.125 & 42.937 & 46 & 17 & 817 & 200512 \\
\hline 2003 & 15.898 & 1.136 & 5.454 & 6.571 & 3.541 & 35.144 & 4.010 & 721 & 184 & - & 319 & 2.784 & 14.686 & 44.945 & 257 & 67152 & 6044 & 208847 \\
\hline 2004 & 18.035 & 1.162 & 5.642 & 6.784 & 3.648 & 35.785 & 4.158 & 730 & 187 & - & 326 & 2.902 & 15.285 & 47.028 & 268 & 69223 & 6278 & 217441 \\
\hline 2005 & 21.076 & 1.174 & 5.764 & 6.917 & 3.711 & 36.354 & 4.258 & 752 & 188 & - & 328 & 2.987 & 15.796 & 49.333 & 276 & 71540 & 6508 & 226963 \\
\hline 2006 & 23.447 & 1.204 & 5.974 & 7.155 & 3.830 & 37.174 & 4.425 & 763 & 192 & - & 336 & 3.120 & 16.474 & 51.732 & 288 & 73906 & 6797 & 236814 \\
\hline 2007 & 26.139 & 1.232 & 6.189 & 7.398 & 3.950 & 37.810 & 4.595 & 772 & 195 & - & 344 & 3.257 & 17.175 & 54.228 & 301 & 76322 & 7096 & 247004 \\
\hline 2008 & 28.897 & 1.261 & 6.409 & 7.646 & 4.073 & 38.625 & 4.771 & 781 & 199 & - & 351 & 3.399 & 17.875 & 56.824 & 314 & 78791 & 7329 & 257543 \\
\hline 2009 & 31.823 & 1.289 & 6.634 & 7.898 & 4.197 & 39.347 & 4.951 & 788 & 202 & - & 359 & 3.547 & 18.596 & 59.525 & 327 & 81312 & 7646 & 268441 \\
\hline 2010 & 36.347 & 1.298 & 6.765 & 8.037 & 4.259 & 39.404 & 5.062 & 783 & 203 & - & 360 & 3.645 & 19.047 & 62.334 & 336 & 83887 & 7942 & 279711 \\
\hline
\end{tabular}




\subsection{Setores de Atividade com Potencial de Cogeração}

Todos os setores da economia utilizam energia elétrica para iluminação. Alguns setores da economia utilizam energia térmica para produção de calor de outra fonte que não a eletricidade, como exemplo, o setor industrial, que será analisado neste trabalho, necessita de calor em seus processos produtivos, e na maioria dos casos produz esse calor através do uso de combustíveis.

A tabela ํo 6 , a seguir, relaciona alguns setores da indústria, que apresentam potencial para produção de energia elétrica e energia térmica a partir de uma terceira fonte de energia em processos de cogeração. ${ }^{[1]}$

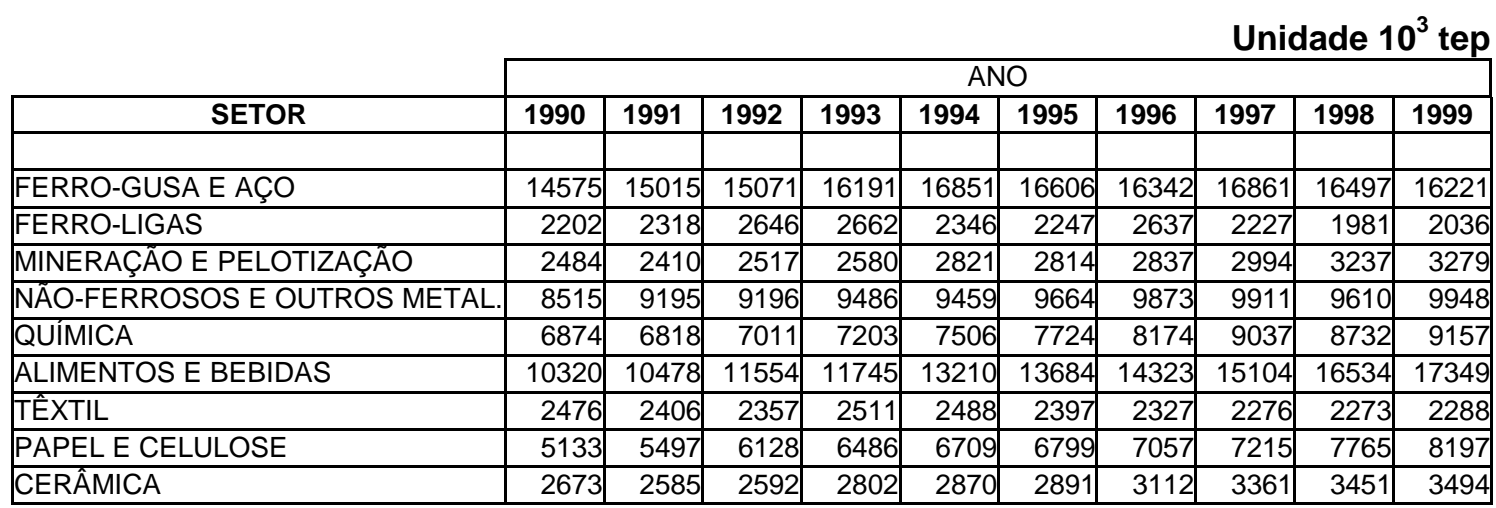

Tabela no 6: Setores industriais com potencial de cogeração

Fonte: Balanço Energético Nacional 2000

A tabela $n^{0} 7$ mostra os energéticos consumidos pelos setores apresentados na tabela ำ 4, sendo destacado em negrito os principais para cada setor. ${ }^{[1]}$

Observa-se na tabela ํo 7, que por exemplo o setor de papel e celulose consome toda lixívia que aparece no balanço energético, sendo ainda grande consumidor de lenha, os dois energéticos são decorrentes do seu próprio 
processo de produção, como esse setor é ainda grande consumidor de energia elétrica, parte dessa eletricidade poderia ser produzida a partir desses energéticos através de processos de cogeração.

Unidade $10^{3}$ tep

\begin{tabular}{|l|r|r|r|r|r|r|}
\hline \multicolumn{1}{|c|}{ FLUXO } & Lixívia & $\begin{array}{c}\text { Óleo } \\
\text { Combustível }\end{array}$ & Eletricidade & $\begin{array}{c}\text { Gás } \\
\text { Natural }\end{array}$ & $\begin{array}{c}\text { Bagaço de } \\
\text { Cana }\end{array}$ & $\begin{array}{c}\text { Lenha e } \\
\text { Carvão }\end{array}$ \\
\hline CONSUMO NA INDÚSTRIA & & & & & & 0 \\
\hline Mineração e Pelotização & 0 & 651 & 1950 & 138 & 0 & 0 \\
\hline Não-Ferrosos e Outros Metal. & 0 & 1018 & 8205 & 52 & 0 & 23 \\
\hline Química & 0 & 1348 & 4731 & 1095 & 34 & 92 \\
\hline Alimentos e Bebidas & 0 & 1010 & 4464 & 219 & 9741 & 1824 \\
\hline Têxtil & 0 & 259 & 1831 & 92 & 0 & 91 \\
\hline Papel e Celulose & 2527 & 25 & 3297 & 213 & 14 & 1121 \\
\hline Cerâmica & 0 & 505 & 786 & 152 & 0 & 1632 \\
\hline
\end{tabular}

Tabela no 7: Energéticos consumidos nos setores industriais

Fonte: Balanço Energético Nacional 2000

\section{CONFIGURAÇÕES TÉCNICAS}

Neste capítulo serão apresentados, a definição da cogeração, seus tipos, os ciclos termodinâmicos utilizados nos processos, e os equipamentos que a viabilizam.

\subsection{Definição da cogeração}

Definida como o processo de transformação de uma forma de energia em mais de uma forma de energia útil.

As formas de energia útil mais freqüentes são a energia mecânica e a térmica. A energia mecânica pode ser utilizada diretamente no acionamento de equipamentos ou para geração de energia elétrica. A energia térmica é utilizada diretamente no atendimento das necessidades de calor para processos, ou indiretamente na produção de vapor ou na produção de frio. 


\subsection{Tipos de Cogeração}

A partir do uso calor útil no processo a cogeração pode ser classificada em dois grandes grupos (tipos):

- A cogeração de "topping"; e

- A cogeração de "bottoming".

Na cogeração de "topping", a energia útil de acionamento é extraída no nível mais alto da combustão, e o calor útil no nível mais baixo.

$\mathrm{Na}$ cogeração de "bottoming" o acionamento é o resultado da recuperação do calor de um processo que o utiliza a temperaturas mais elevadas. As figuras 1 e 2 a seguir ilustram os dois tipos: a primeira é "bottoming" e a segunda "topping".

Figura 1 - cogeração bottoming Fonte: do autor
Figura 2 - cogeração topping

Fonte: do autor
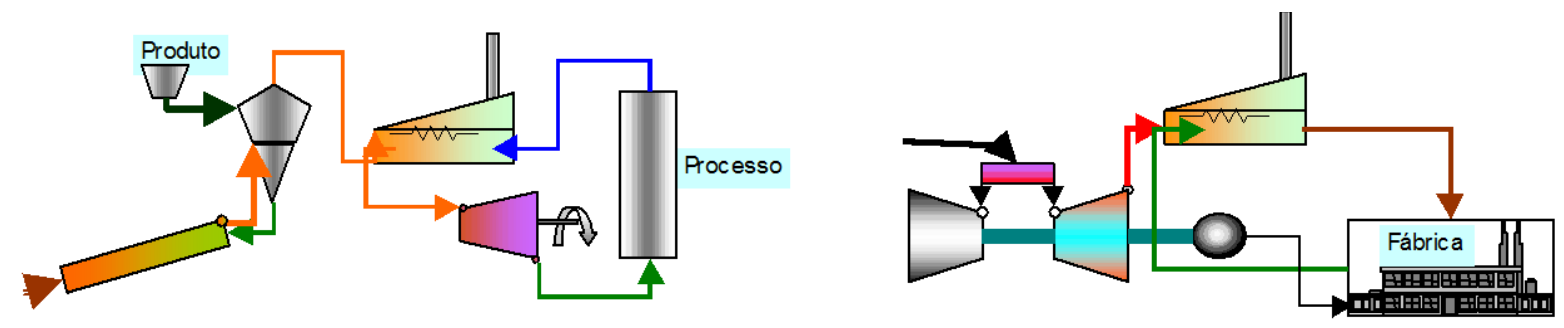

Independente do grupo, ou tipo de cogeração, será feita a análise técnica por ciclos termodinâmicos, que possuem, cada um deles, tecnologia própria com equipamentos específicos e conseqüentemente eficiências e aplicações distintas. 


\subsection{Ciclos Termodinâmicos}

\subsubsection{Ciclos Otto e Diesel}

Estes ciclos de cogeração utilizam motores alternativos de combustão interna produzindo trabalho (energia elétrica ou acionamento mecânico) recuperando a energia térmica residual dos gases de exaustão, e eventualmente, o calor dos sistemas de lubrificação de resfriamento das camisas dos pistões.

A quantidade de energia residual recuperada não é das mais expressivas, por isso sua aplicação mais freqüente ocorre nas instalações que necessitam de pequenas quantidades de calor a temperatura moderada e maior quantidades de energia elétrica ou força motriz.

São comuns plantas de cogeração utilizando estes ciclos, nas potências de poucas dezenas de $\mathrm{kW}$ até potências da ordem de $20 \mathrm{MW}$.

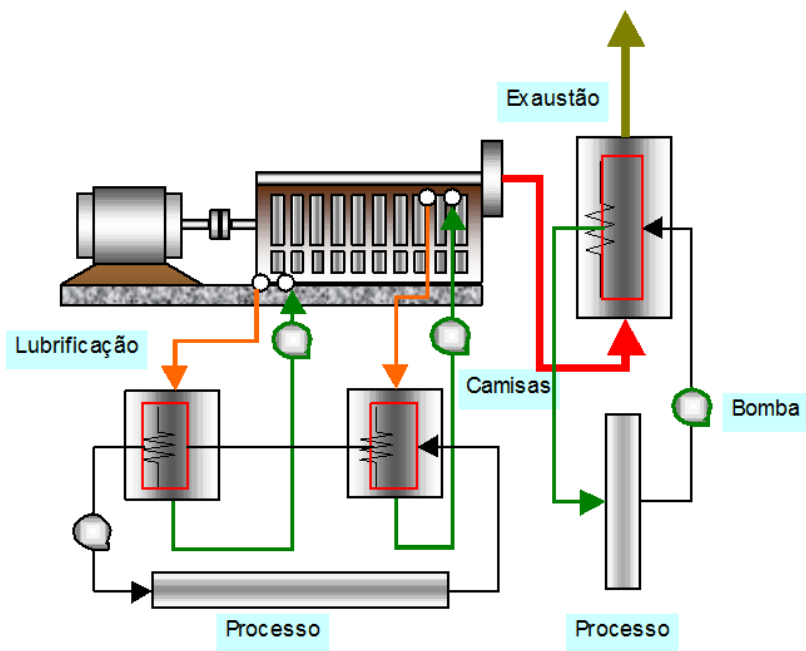

Figura 3 - Esquema de ciclo de cogeração com motor Fonte: do autor 


\subsubsection{Ciclo Rankine}

Neste ciclo a energia térmica resultante da combustão é transferida, através de caldeira, para a água que vaporiza e superaquece. O vapor superaquecido é expandido em uma turbina que aciona uma carga mecânica (ou gerador elétrico). O vapor é extraído na saída da turbina, nas condições de temperatura e pressão requeridas para o processo que utiliza este calor útil. Geralmente o fluido é devolvido à caldeira no estado de condensado para reinicializar o ciclo de transferência de energia.

O "Ciclo Rankine" permite a utilização de combustíveis mais baratos, como resíduos industriais, carvão, lenha, bagaço de cana, etc., muitas vezes os únicos disponíveis no local.

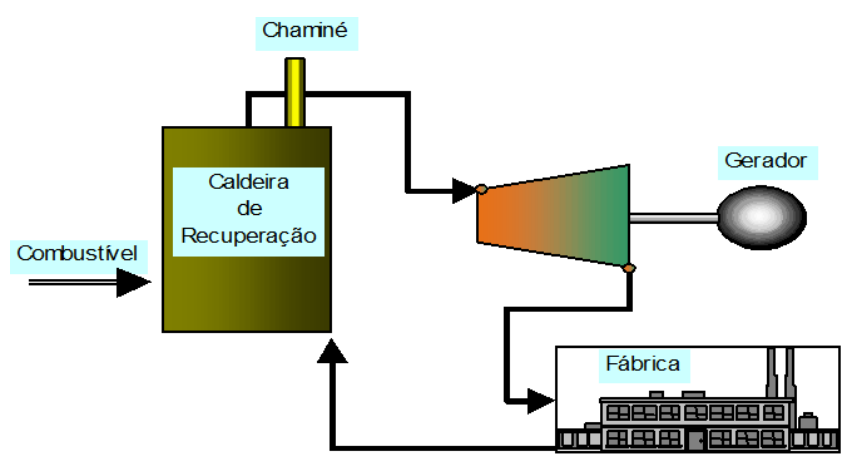

Figura 4 - Esquema de cogeração ciclo Rankine Fonte: do autor

\subsubsection{Ciclo Brayton}

Na saída da turbina a gás, os gases de exaustão apresentam ainda uma temperatura relativamente elevada, da ordem de 380 a $600{ }^{\circ} \mathrm{C}$. Estes gases 
possuem elevado conteúdo energético, da ordem de 50 a $70 \%$ da energia contida no combustível.

A cogeração se baseia no aproveitamento de parte desta energia térmica. Dependendo das características da carga térmica, o aproveitamento pode ser maior ou menor. Os processos que utilizam temperaturas mais baixas podem aproveitar mais energia residual dos gases de exaustão.

Os usos mais freqüentes para esta energia são a utilização dos gases quentes para secagem, geração de vapor através de uma caldeira de recuperação, aquecimento de fluído térmico, condicionamento ambiental, etc. A figura seguinte mostra uma instalação de cogeração onde uma turbina a gás aciona um gerador que produz energia elétrica que alimenta a fábrica que hospeda a instalação. Os gases quentes da saída da turbina produzem vapor em uma caldeira de recuperação que alimenta a fábrica com esta utilidade.

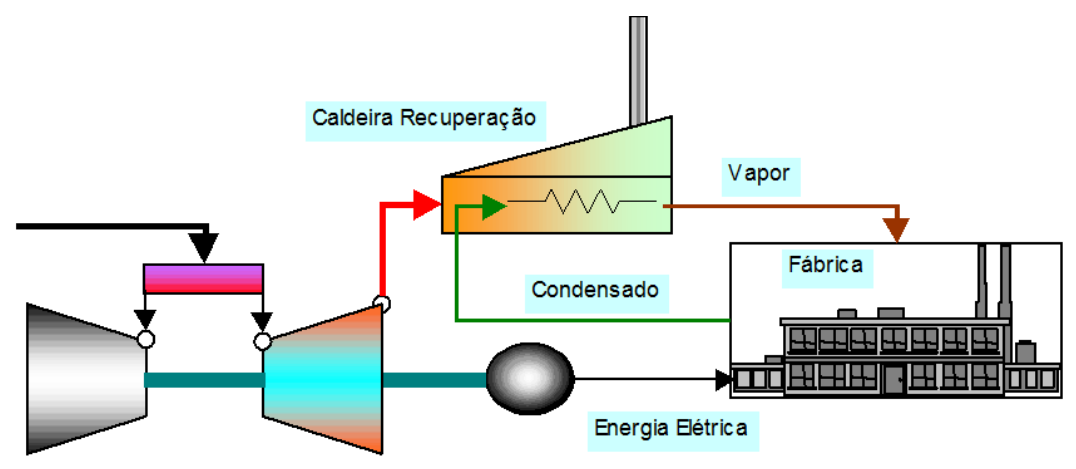

Figura 5 - Cogeração com ciclo Brayton aproveitando o calor Fonte: do autor 


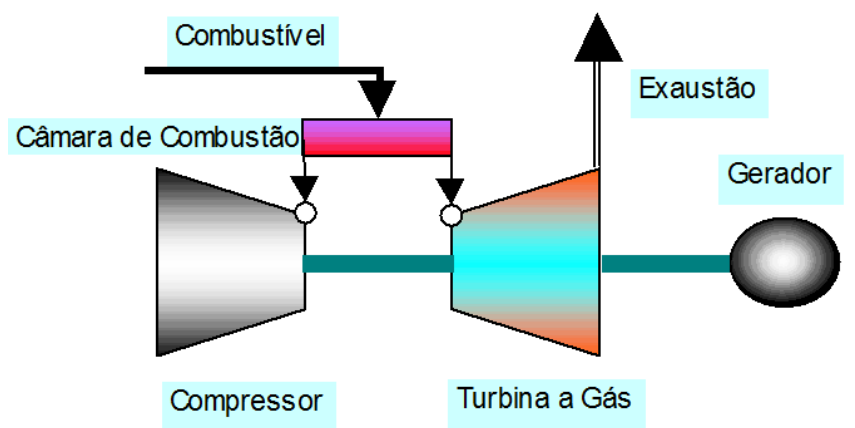

Figura 6 - Cogeração com ciclo Brayton Fonte: do autor

A carga acoplada ao eixo (ou eixos) da turbina, além do compressor de ar do conjunto, pode ser constituída por gerador de energia elétrica, bombas, compressores ou um eixo motor qualquer. As turbinas de pequena e média potência giram a rotações mais elevadas. Dependendo da carga, pode ser necessário inserir um redutor de velocidade entre a turbina e sua carga. Algumas turbinas possuem mais de um eixo: neste caso, cada eixo acionado por um conjunto de pás de turbina, gira a velocidade diferente.

Por razões de limitação de temperatura suportável pelos materiais de construção das turbinas, a massa de ar injetada na câmara da combustão é muito superior à quantidade requerida para se estabelecer a reação estequiométrica da combustão. Assim, os gases de exaustão da turbina contém ainda uma quantidade significativa de oxigênio.

Quanto mais elevada for a temperatura e a pressão dos gases na entrada do primeiro estágio da turbina, e quanto mais reduzida for a temperatura dos gases de exaustão, maior será a eficiência da turbina a gás. A evolução tecnológica dos fatores que afetam estes parâmetros tem promovido, nos últimos anos, o contínuo aperfeiçoamento destas máquinas. 
O compressor de ar consome uma parcela significativa da energia mecânica resultante da conversão da energia térmica dos combustíveis.

\subsubsection{Ciclo Combinado}

O ciclo combinado é o processo de produção de energia elétrica utilizando turbinas a gás e turbinas a vapor. O combustível é queimado em uma turbina a gás e a energia contida nos gases de exaustão produz vapor em uma caldeira de recuperação. O vapor da caldeira de recuperação aciona uma turbina a vapor de condensação. Tanto a turbina a gás quanto à turbina a vapor acionam geradores para produção de energia elétrica, que é a única forma de energia útil retirada do sistema.

Este ciclo prioriza a eficiência de conversão da energia do combustível para a energia elétrica. As grandes termoelétricas em ciclo combinado atingem atualmente uma eficiência da ordem de $57 \%$.

Esta forma de cogeração é utilizada nas situações em que se deseja produzir energia elétrica e energia térmica úteis em quantidades variáveis de acordo com as cargas consumidoras ou para atendimento de mercados específicos. É constituído basicamente de um ciclo combinado com flexibilização da geração elétrica e da energia térmica (normalmente vapor) através da extração de vapor na turbina (condensação parcial), queima suplementar de combustível na caldeira de recuperação. Existem plantas tão flexíveis que podem operar desde a produção máxima de energia elétrica sem extração de vapor para o processo industrial até a produção máxima de vapor para processo sem produção de energia elétrica. 
Outra forma de cogeração deste tipo é aquela em que os acionamentos são de equipamentos mecânicos (bombas, compressores, etc.) ao invés de geradores elétricos.

A queima adicional de combustíveis pode reduzir os custos globais de operação, em determinadas situações por utilizar combustíveis mais baratos. A eficiência pode ser muito elevada, dependendo do balanço de massa e energia que se obtém em determinados projetos. A figura seguinte mostra uma configuração deste ciclo.

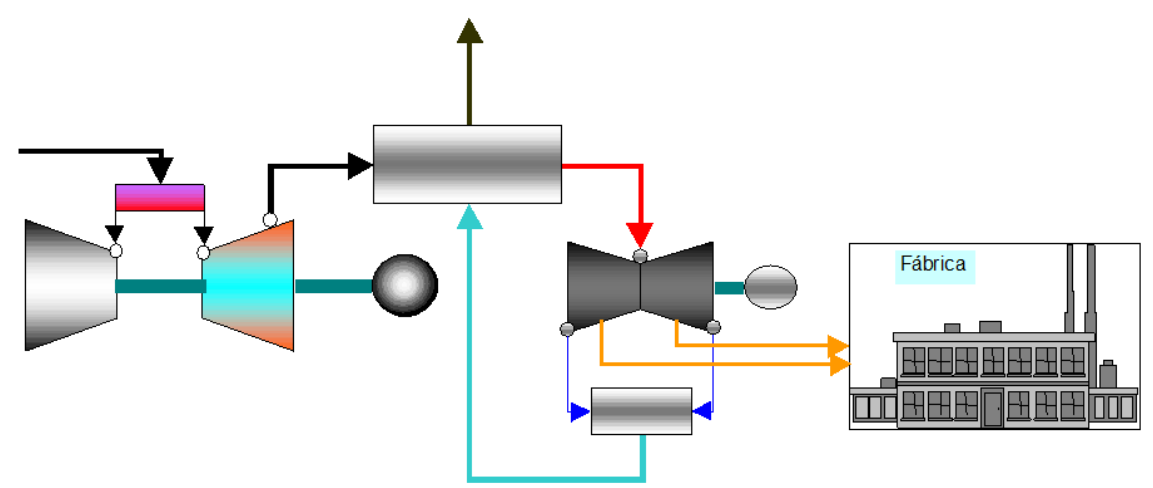

Figura 7 - Esquema de cogeração com ciclo combinado Fonte: do autor

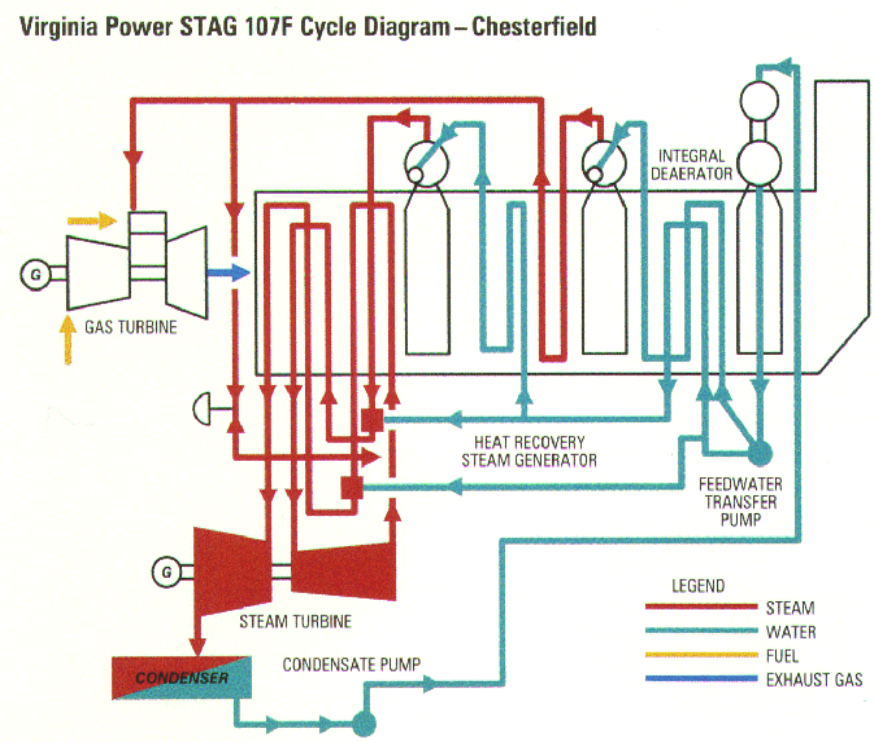


Figura 8 - Esquema de operação de uma instalação de ciclo combinado

Fonte: Catálogo de fabricante de turbina

\subsection{Equipamentos}

A seguir será feita uma breve descrição dos equipamentos utilizados nos conjuntos de geração termoelétrica e de cogeração.

\subsubsection{Motores Alternativos de Combustão Interna}

Os motores alternativos de combustão interna são máquinas que transformam a energia térmica de um combustível em energia mecânica através do acionamento de pistões confinados em cilindros.
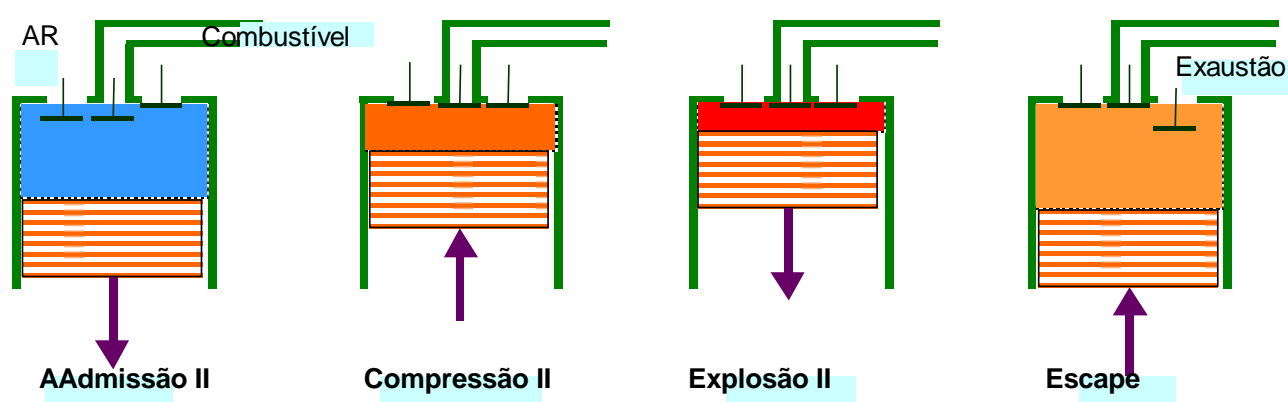

Figura 9 - Esquema de um ciclo de motor de combustão (Diesel) Fonte: do autor
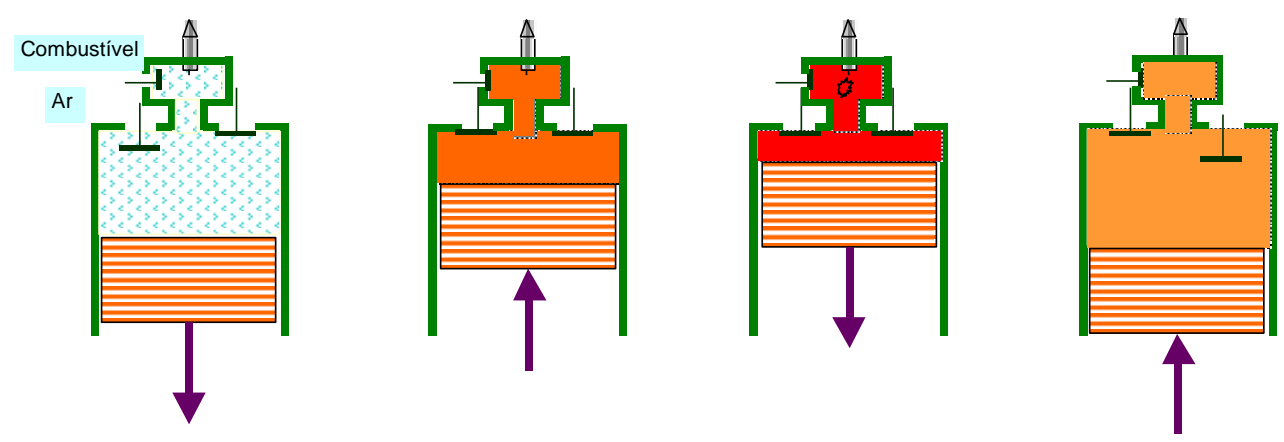

Figura 10 - Esquema de um ciclo de motor de combustão (Otto) Fonte: do autor

\subsubsection{Turbinas a vapor}


São máquinas que convertem a energia térmica do vapor em energia mecânica para acionamentos. Podem ser fabricadas sob uma extensa gama de configurações, para diversas pressões, diferentes números de estágios, de condensação, de extração simples e controlada, simples e múltiplas entradas, etc.

São produzidas na faixa de potência desde poucos kW até pouco mais de $1.000 \mathrm{MW}$.

A figura 11 mostra alguns dos tipos de turbinas a vapor usualmente utilizadas em instalações de cogeração:
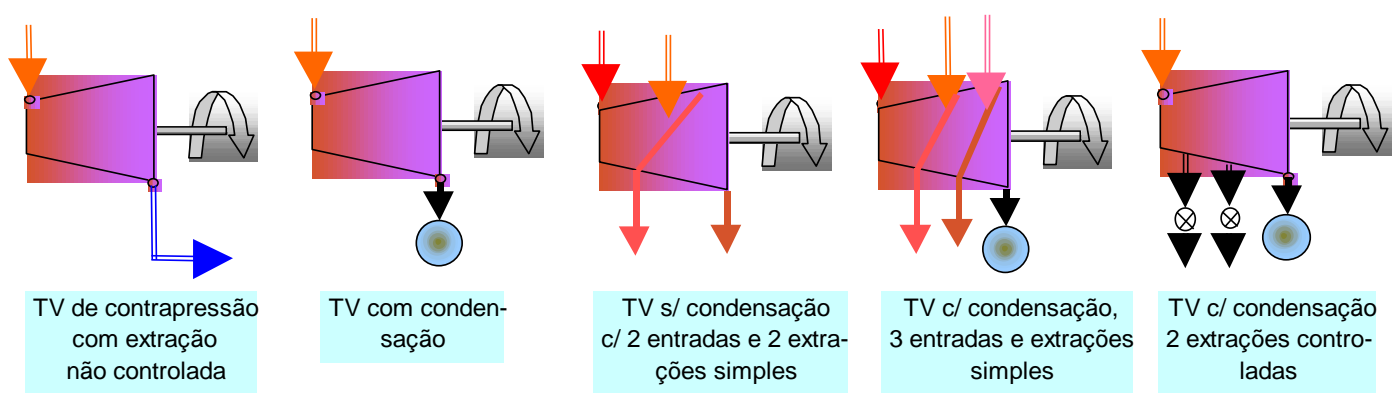

Figura 11 - Esquema de turbinas a vapor

Fonte: do autor

\subsubsection{Turbinas a gás}

As turbinas a gás são equipamentos constituídos por compressor, câmara de combustão e a turbina de expansão. O ar comprimido é injetado na câmara de combustão fornecendo o oxigênio para a queima do combustível. Esta reação exotérmica à alta pressão transfere a energia química do combustível para os gases, elevando sua temperatura. O gás resultante é expandido na turbina, de onde se extrai a energia mecânica para acionamento do compressor e da carga acoplada ao eixo. Nas turbinas usadas em aviões a 
jato, os gases quentes são exauridos através de bocais que transformam a energia dos gases em empuxo.

As turbinas a gás estão disponíveis desde a potência de poucas centenas de $\mathrm{kW}$ até quase $300 \mathrm{MW}$.

\subsubsection{Caldeiras}

As caldeiras são equipamentos construídos para aquecer um fluido ou produzir vapor a partir da queima de combustíveis. De acordo com as necessidades do consumo o vapor pode ser produzido nas condições de saturação ou superaquecido.

As caldeiras de combustão utilizam uma gama muito extensa de combustíveis sólidos, líquidos e gasosos.

Existem dois tipos construtivos de caldeiras:

as flamotubulares, onde os gases quentes circulam em tubos e o fluido a aquecer circula externamente aos tubos, essas caldeiras são de menor porte, e pouco utilizadas para processos de produção de energia elétrica.

as aquatubulares, funcionam de forma inversa, o fluido circula no interior de tubos e os gases quentes circulam por fora, geralmente são caldeiras de maior porte, as também chamadas de caldeiras de parede d'água, são as mais utilizadas nos processos de geração de eletricidade, onde se requer grandes vazões de vapor a altas pressões e temperaturas.

Além dessa classificação, nos sistemas de cogeração, ou geração termoelétrica, é comum a utilização das chamadas caldeiras de recuperação. 
As caldeiras de recuperação de calor são muito utilizadas em cogeração de energia elétrica e térmica, para recuperar o calor residual dos gases de exaustão de turbinas a gás ou de motores alternativos, ou de algum processo produtivo que produza calor.

Nas aplicações de recuperação de calor de turbinas a gás, este equipamento pode ser muito sofisticado. É comum, ser projetado e construído para múltiplas pressões, com troca de calor gás-líquido. Nas aplicações que exigem maior produção de vapor, maior pressão e temperatura ou maior flexibilidade de operação, são, algumas vezes dotados de queima suplementar de combustível, exaurindo ou não, o oxigênio residual da queima do combustível da turbina a gás. Dependendo da quantidade de combustível adicional pode ser necessário adição de ar para queima. Quando possível, o combustível suplementar queimado é de custo menor que o combustível da turbina a gás.

Os motores alternativos de combustão interna permitem outras formas de recuperação de energia além contida nos gases de exaustão. Os circuitos de refrigeração das camisas e o sistema de resfriamento de óleo são duas outras fontes de recuperação. A recuperação nos gases é feita com caldeiras de recuperação mais simples em razão do seu conteúdo energético. Nos demais circuitos a recuperação é feita com trocadores de calor líquido- líquido.

\subsubsection{Trocadores de calor}


Os trocadores de calor dos tipos gás-líquido, gás-gás e líquido-líquido são amplamente utilizados em instalações térmicas industriais em geral e de cogeração, ou geração termoelétrica em particular.

\subsubsection{Equipamentos auxiliares}

Consideram-se equipamentos auxiliares aqueles necessários para completar as instalações de cogeração ou de geração termoelétrica, tais como: motores auxiliares, sistemas de tratamento de água e efluentes, ar comprimido, transformadores, proteções elétricas, etc..

\subsubsection{Equipamentos de conversão de energia mecânica em elétrica}

Os equipamentos utilizados para conversão de energia mecânica em elétrica são os alternadores. Os alternadores são acionados por motores ou por turbinas a gás ou vapor. De acordo com a velocidade da máquina motora pode ser necessário utilizar-se de redutores de velocidade.

\subsection{Ciclo de Absorção}

Apesar do ciclo de absorção não ser utilizado diretamente em sistemas de cogeração, não poderia ser excluído deste trabalho, pois a utilização deste ciclo, em conjunto com o ciclo Brayton, por exemplo, pode ser a única forma de viabilizar uma cogeração em atividades comerciais. Este ciclo também pode 
ser utilizado em indústrias que precisam de condicionamento ambiental, ou ambientes limpos, como é o caso da indústria farmacêutica.

Em resumo, os mercados potenciais para este ciclo são os hospedeiros da planta de cogeração, que necessitam, além da energia elétrica, de condicionamento ambiental ou sistema de refrigeração.

O calor residual proveniente de algum processo ou equipamento como uma turbina ou um motor, pode ser a fonte quente desse ciclo.

O exemplo mostrado na figura seguinte ilustra o princípio básico de funcionamento desse ciclo. É mostrado um ciclo frigorífico com solução de amônia.

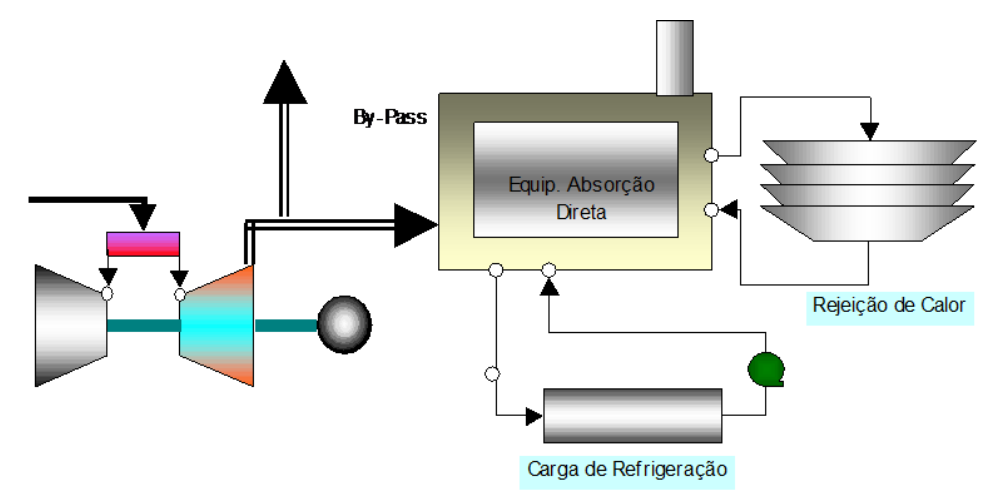

Figura 12 - Esquema de cogeração com ciclo de absorção Fonte: do autor

Esta solução (de concentração elevada) é bombeada do absorvedor "A" para o interior de um trocador de calor "B" onde evapora absorvendo a energia proveniente de uma fonte quente dando origem ao vapor de amônia (em alta pressão). O vapor de amônia é conduzido ao condensador "C", onde ao condensar cede calor que é rejeitado do processo. O líquido condensado é 
conduzido ao evaporador "D", através de uma válvula de expansão, No evaporador "D" o líquido condensado evapora, extraindo calor do meio em que está contido (câmara frigorífica, por exemplo). Em seguida, o vapor de amônia a baixa pressão junta-se no absorvedor "A" com a solução, agora de baixa concentração, e se reinicia o ciclo.

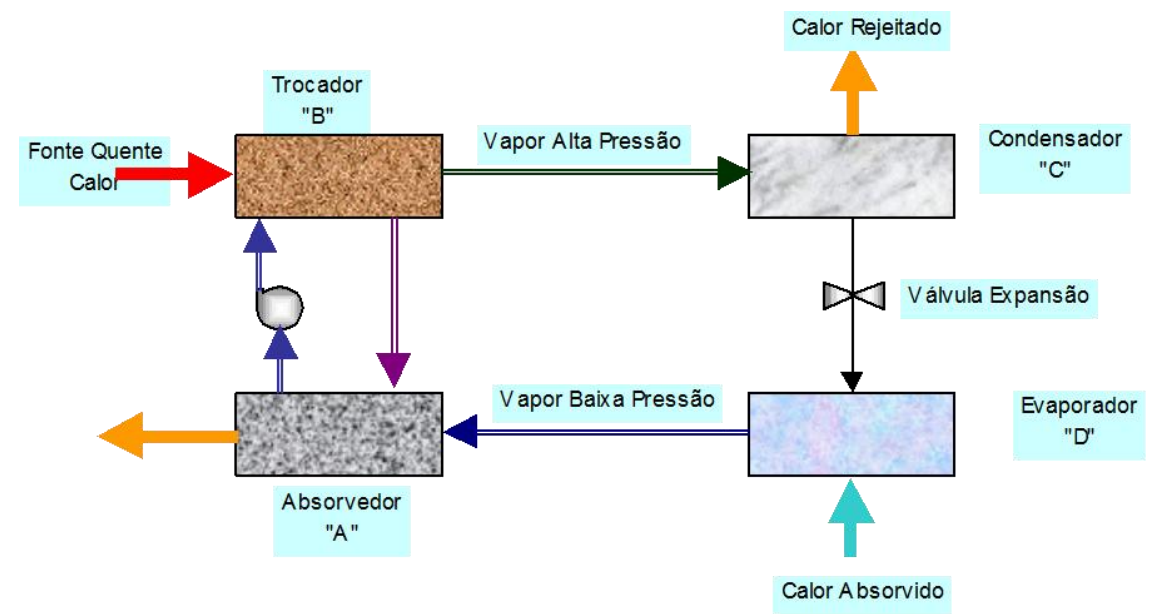

Figura 13 - Esquema de operação do ciclo de absorção Fonte: do autor

\subsubsection{Equipamentos de absorção}

Os equipamentos frigoríficos com ciclo de absorção utilizam energia térmica para produção do frio.

Os equipamentos de absorção são produzidos industrialmente para capacidades de 100 até cerca de 2.000 toneladas de refrigeração por hora. São comuns os de um e de dois estágios.

Os equipamentos ideais para este uso são os resfriadores por absorção. A figura 14 ilustra algumas aplicações deste tipo. 


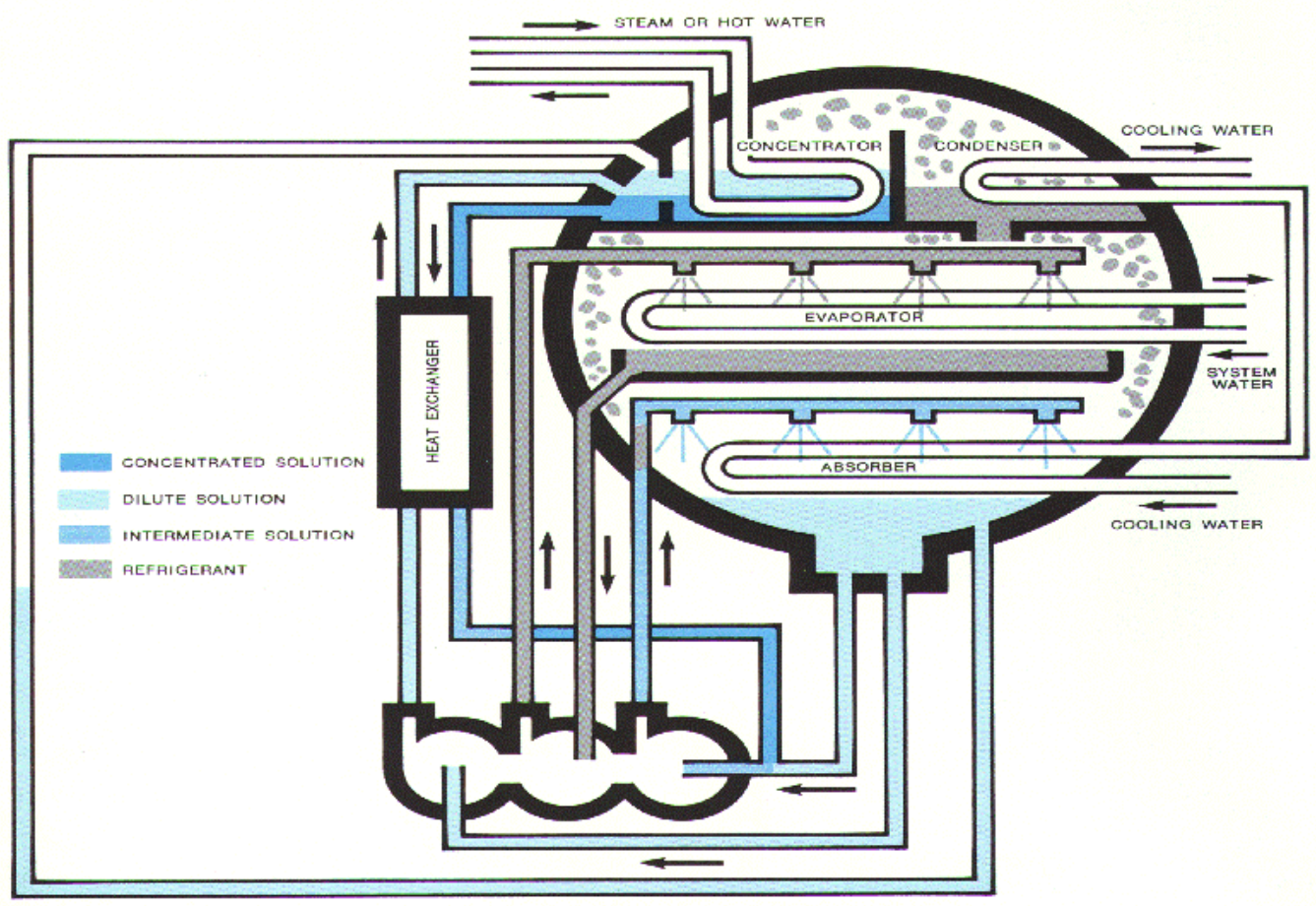

Figura 14 - Evaporador de equipamento de absorção Fonte: Catálogo de fabricante (York)

\subsection{Eficiência}

$\mathrm{Na}$ prática encontram-se em conjuntos de equipamentos disponíveis no mercado, as eficiências apresentadas na tabela $n^{\circ}-8$.

\begin{tabular}{|l|c|c|c|c|}
\hline \multicolumn{1}{|c|}{$\mathbf{n}$} & $\begin{array}{c}\text { Otto ou } \\
\text { Diesel }\end{array}$ & Rankine & Brayton & Combinado \\
\hline Termoelétrica & 40 a $46 \%$ & 30 a $45 \%$ & 35 a $45 \%$ & $57 \%$ \\
\hline Cogeração & $62 \%$ & $50 \%$ & 70 a $75 \%$ & 70 a $75 \%$ \\
\hline
\end{tabular}

Tabela no 8 - Eficiências de sistemas de cogeração

Fonte: Consulta a diversos fabricantes de equipamentos (caldeiras de recuperação, e turbinas) 


\section{Análise ambiental}

O estudo do impacto ambiental dos processos de geração termoelétrica, tanto nas térmicas convencionais, quanto em processos de cogeração são semelhantes.

As premissas adotadas na análise ambiental, para que possam ser comparados dois empreendimentos de produção de energia elétrica, um com cogeração e outro com unidades termoelétricas convencionais com ciclo de vapor são:

- os dois empreendimentos usam a mesma fonte de energia primária, por exemplo, o gás natural;

- os dois empreendimentos produzem a mesma quantidade de energia útil. $\mathrm{Na}$ cogeração devem ser somadas a eletricidade com a energia térmica utilizada nos processos produtivos. Na geração térmica convencional a energia útil é somente a eletricidade.

Para melhor visualizar o resultado da análise de impacto ambiental, será mostrado o exemplo de uma instalação térmica convencional, e um processo de cogeração equivalente, com as seguintes características:

\begin{tabular}{|l|l|l|}
\hline & \multicolumn{1}{|c|}{ Termoelétrica } & \multicolumn{1}{c|}{ Cogeração } \\
\hline Ciclo termodinâmico & Combinado & Combinado \\
\hline Combustível & Gás Natural & Gás Natural \\
\hline Eletricidade Produzida & $1 \mathrm{MW}$ & $1 \mathrm{MW}$ (equivalente) \\
\hline Eficiência global $\left(^{*}\right)$ & $54,8 \%$ & $72 \%$ \\
\hline
\end{tabular}

Tabela no 9 Dados das instalações

${ }^{*}$ *) A diferença de eficiência se dá devido ao aproveitamento da energia térmica no processo de cogeração. 


\subsubsection{Dados para o gás natural}

PCS- do gás natural $\left(\mathrm{Kcal} / \mathrm{m}^{3}\right) \quad 9400$

PCS- do gás natural $\left(\mathrm{kWht} / \mathrm{m}^{3}\right) \quad 10,93$

$\mathrm{PCl}$-do gás natural $\left(\mathrm{kWht} / \mathrm{m}^{3}\right) \quad 9,76$

relação $\mathrm{PCS} / \mathrm{PCl} \quad 1,12$

Consumo para termoelétrica (ciclo Combinado) $=187,03\left(\mathrm{~m}^{3} / \mathrm{MWh}_{\mathrm{e}}\right)\left(^{*}\right)$

Consumo para cogeração (Ciclo Combinado)

O consumo específico apresentado a seguir, para o caso de cogeração considera um empreendimento de porte similar ao da unidade termelétrica e será dado em função do $\mathrm{MWh}_{\mathrm{e}}$ equivalente, ou seja, será a soma do $\mathrm{MWh}_{\mathrm{e}}$

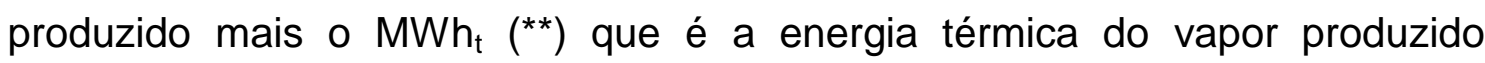
convertido em $\mathrm{MWh}_{\mathrm{e}}$.

Consumo específico de gás natural $=127,07\left(\mathrm{~m}^{3} / \mathrm{MWh}_{\mathrm{e}}\right.$ equivalente $)$

\subsubsection{Emissão de gases}

A tabela $n^{0} 10$, apresenta as emissões de gases poluentes decorrentes da queima de gás natural em turbinas de grande porte, e servem de referência para os dois empreendimentos. As emissões para o empreendimento de cogeração serão menores que na termelétrica, visto que o consumo de gás natural para produzir a mesma energia útil é significativamente menor para a cogeração. 


\begin{tabular}{|c|c|c|}
\hline Poluentes & Fator de emissão & Fator de emissão \\
\hline & Ib/MMBtu & kg/MMBtu \\
\hline $\mathrm{NO}_{x}$ & 0,3200 & 0,1451 \\
\hline CO & 0,0820 & 0,0372 \\
\hline $\mathrm{CO}_{2}$ & 110 & 49,8952 \\
\hline $\mathrm{N}_{2} \mathrm{O}$ & 0,003 & 0,0014 \\
\hline $\mathrm{SO}_{\mathrm{x}}$ & 0,0034 & 0,0015 \\
\hline $\mathrm{CH}_{4}$ & 0,0086 & 0,0039 \\
\hline VOC & 0,0021 & 0,0010 \\
\hline TOC & 0,0110 & 0,0050 \\
\hline PM - total & 0,0066 & 0,0030 \\
\hline PM - filtráveis & 0,0019 & 0,0009 \\
\hline PM - Condens & 0,0047 & 0,0021 \\
\hline
\end{tabular}

Tabela 10 - Emissão de gases para turbinas de grande porte (valores para cada MWh produzido)

Fonte: quantidades calculadas pelo autor

A tabela $n^{0} 11$ mostra a comparação das quantidades de poluentes emitidos por hora para produção da mesma quantidade de energia nos dois empreendimentos.

\begin{tabular}{|l|r|r|}
\hline \multirow{2}{*}{ Poluentes } & \multicolumn{1}{|c|}{ Termelétrica } & \multicolumn{1}{c|}{ Cogeração } \\
\cline { 2 - 3 } & $\mathbf{k g} / \mathbf{h}$ & $\mathbf{k g} / \mathbf{h}$ \\
\hline $\mathbf{N O} \mathbf{x}_{\mathbf{x}}$ & $64,28 \times 10^{-3}$ & $43,68 \times 10^{-3}$ \\
\hline $\mathbf{C O}$ & $16,48 \times 10^{-3}$ & $11,20 \times 10^{-3}$ \\
\hline $\mathbf{C O}{ }_{2}$ & 22,11 & 15,02 \\
\hline $\mathbf{N}_{\mathbf{2}} \mathbf{O}$ & $0,62 \times 10^{-3}$ & $0,42 \times 10^{-3}$ \\
\hline $\mathbf{S O} \mathbf{x}$ & $0,66 \times 10^{-3}$ & $0,45 \times 10^{-3}$ \\
\hline $\mathbf{C H}$ & $1,73 \times 10^{-3}$ & $1,17 \times 10^{-3}$ \\
\hline $\mathbf{V O C}$ & $0,44 \times 10^{-3}$ & $0,30 \times 10^{-3}$ \\
\hline $\mathbf{T O C}$ & $2,22 \times 10^{-3}$ & $1,50 \times 10^{-3}$ \\
\hline $\mathbf{P M}$ - total & $1,33 \times 10^{-3}$ & $0,90 \times 10^{-3}$ \\
\hline $\mathbf{P M}$ - filtráveis & $0,40 \times 10^{-3}$ & $0,27 \times 10^{-3}$ \\
\hline $\mathbf{P M}$ - Condens & $0,93 \times 10^{-3}$ & $0,63 \times 10^{-3}$ \\
\hline
\end{tabular}

Tabela $\mathrm{n}^{\circ} 11$ - Emissão de gases para os dois processos (valores para cada MWh produzido)

Fonte: calculados pelo autor 


\section{Conclusão técnica}

Tudo o que foi visto no item anterior, demonstra que a tecnologia utilizada nos empreendimentos de geração termoelétrica ou de cogeração está dominada, e amplamente difundida.

Os ciclos termodinâmicos são iguais e aplicáveis aos dois casos, é possível tecnicamente gerar eletricidade ou cogerar (eletricidade + calor) em qualquer dos ciclos. Porém é sabido que para geração de eletricidade são utilizados: o "Ciclo Otto ou Diesel", o "Ciclo Rankine", o "Ciclo Brayton" e o "Ciclo Combinado".

\section{Equipamentos:}

Os equipamentos utilizados tanto para cogeração, como para geração termelétrica são similares, e possuem tecnologia conhecida e da mesma forma disponível. A diferença fundamental consiste na forma de concepção do projeto e na aplicação que se vai dar a energia produzida.

\section{Eficiência:}

Pode-se afirmar que a cogeração apresenta vantagens de eficiência em relação à geração termelétrica, pela destinação final da energia produzida. Enquanto na geração termelétrica uma parte do calor é sempre desprezada, na cogeração esse calor alimenta processos produtivos, fazendo com que a eficiência global seja superior.

\section{Meio Ambiente:}

Como a cogeração apresenta eficiência global superior, sua agressão ao meio ambiente é menor que nos processos termelétricos. 
Dos tópicos descritos anteriormente pode-se concluir que existem vantagens técnicas para a cogeração sobre a geração termelétrica.

\section{Legislação e Quadro Institucional}

A legislação do setor elétrico no Brasil é bastante abrangente, e abundante na quantidade de Leis, Portarias, Decretos e Resoluções.

Serão citadas a seguir algumas leis que dizem respeito, direta ou indiretamente, às questões de geração termelétrica e da cogeração.

Decreto No 2.003, de 10 de setembro de 1996

Regulamenta a produção de energia elétrica por Produtor Independente e por Autoprodutor e dá outras providências

Portaria No 459, de 10 de novembro de 1997

Regulamenta as condições para os acessos aos sistemas de transmissão e distribuição, de forma a viabilizar novos investimentos, a competição na geração de energia elétrica e propiciar a expansão da oferta a preços adequados para o consumidor

Decreto no 2.410, de 28 de novembro de 1997.

Dispõe sobre o cálculo e o recolhimento da Taxa de Fiscalização de Serviços de Energia Elétrica instituída pela Lei n. 9.427, de 26 dezembro de 1996, e dá outras providências. 
Decreto № $2.457,14$ de janeiro de 1998.

Dispõe sobre a estrutura e funcionamento do Conselho Nacional de Política Energética - CNPE e dá outras providências

Decreto oㅜ 2.655 de 02.de julho de 1998.

Regulamenta o Mercado Atacadista de Energia Elétrica, define as regras de organização do Operador Nacional do Sistema Elétrico, de que trata a Lei no 9.648, de 27 de maio de 1998, e dá outras providências.

Resolução no 248 de 07 de agosto de 1998

Estabelece as condições gerais da prestação de serviços de transmissão, de contratação do acesso e uso dos sistemas de transmissão de energia elétrica, vinculadas à celebração dos contratos iniciais.

Resolução no 264 de 13.de agosto de 1998

Estabelece as condições para contratação de energia elétrica por consumidores livres.

Resolução no 265 de 13 de agosto de 1998

Estabelece as condições para o exercício da atividade de comercialização de energia elétrica. 
Resolução no 307 de 30 de setembro de 1998

Aprova o Estatuto do Operador Nacional do Sistema Elétrico - ONS.

Resolução no 315 de 01 de outubro de 1998

Estabelece mudanças no mecanismo de reembolso previsto na sistemática da Conta de Consumo de Combustíveis Fósseis - CCC para os Sistemas Isolados, de forma a ser considerado o atendimento 24 horas por dia.

Resolução no 351 de 11 de novembro de 1998

Autoriza o Operador Nacional do Sistema Elétrico - ONS, a executar as atividades de coordenação e controle da operação da geração e transmissão de energia elétrica nos sistemas interligados.

Portaria CSPE - 17, de 15-9-99

Dispõem sobre os níveis tarifários, classificação em segmentos e enquadramento das classes de tarifas praticadas pela Concessionária de distribuição de gás canalizado na área de concessão Noroeste e demais providências pertinentes

Portaria CSPE - 28, de 22-2-2000

Dispõe sobre os níveis tarifários, classificação em segmentos e enquadramento das classes de tarifas praticadas pela Concessionária de distribuição de gás canalizado na área de concessão Sul e demais providências pertinentes. 
Resolução ํo 281 de 01 de outubro de 1999

Estabelece as condições gerais de contratação do acesso, compreendendo o uso e a conexão aos sistemas de transmissão e distribuição de energia elétrica.

Resolução № 282 de 01 de outubro de 1999

Estabelece as tarifas de uso das instalações de transmissão de energia elétrica, componentes da Rede Básica do Sistema Elétrico Interligado.

Resolução № 286 de 01 de outubro de 1999

Estabelece as tarifas de uso dos sistemas de distribuição de energia elétrica.

Resolução oㅜ 371 de 29 de dezembro de 1999

Regulamenta a contratação e comercialização de reserva de capacidade por autoprodutor ou produtor independente, para atendimento de unidade consumidora diretamente conectada às suas unidades de geração.

A legislação citada acima não esgota o assunto, e deve-se ressaltar que o cenário brasileiro para energia ainda não está totalmente definido, o processo de transformação encontra-se em andamento, com novas leis surgindo com freqüência.

Analisando as leis existentes, com objetivo de traçar um cenário, atentando para diferenças entre geração térmica e cogeração no Brasil, não encontramos vantagens legais para nenhum processo. 
Em outros países da Europa, ou mesmo nos Estados Unidos, existe legislação específica para cogeração, por entender esses países que a cogeração não pode ser desprezada principalmente nos processos industriais.

Nos EUA o PURPA ${ }^{[2]}$, Public Utility Regulatory Policies Act, criado em 1978, para incentivo a conservação de energia e aos empreendimentos de geração de eletricidade, é uma lei que obriga as concessionárias à compra de excedentes de eletricidade produzida por cogeração, lei semelhante existe na Espanha e em Portugal o Decreto ํㅜ 538/99 de 13 d3 dezembro de 1999, alterado pela resolução do Conselho de Ministros № 154/2001 de 27 de setembro de 2001. Deve-se ressaltar que essas leis privilegiam os processos de cogeração, e as tarifas previamente estabelecidas acabaram por distorcer o mercado, sendo consideradas excessivas. Com a comercialização garantida, e tarifas acima das praticadas no mercado, corre-se grande risco de tornarem-se viáveis projetos não tão eficientes.

Por outro lado no Brasil, medidas estão sendo tomadas para privilegiar os processos de geração termelétrica, como exemplo tarifas menores para o gás natural, as quais os processos de cogeração não têm acesso. Deve-se alertar que tal medida discriminatória é uma forma de desestímulo ao investidor em cogeração industrial.

\section{Análise Econômica}

A análise econômica dos empreendimentos para produção de eletricidade, passa necessariamente por preços dos energéticos a serem 
utilizados, além dos preços praticados pelo mercado da própria energia elétrica a ser produzida, tem grande influência nas decisões também os preços dos equipamentos, dos custos de manutenção e operação das instalações geradoras, bem como impostos e taxas a que o empreendimento estará sujeito. Será apresentada, a seguir, a situação atual desses itens, com breves comentários em cada ponto analisado.

\subsection{Preços dos energéticos}

As tarifas de combustíveis e energia elétrica são hoje desequalizadas, ou seja, não há mais tabelamento imposto pelo Estado, cada fornecedor tem seu próprio preço. A única interferência ainda existente no mercado é a necessidade de homologação das tarifas pelo órgão regulador.

Os preços são praticamente desregulados. Ainda não podemos dizer que as tarifas estão reguladas pelo mercado, pois a competição de fato está apenas começando, e não há disponibilidade de oferta suficiente para a prática da competição. Espera-se que em breve este fato ocorra.

Para efeito de análise, será referenciado como base de cálculos as tarifas da Bandeirante Energia S.A., ressaltando-se que as tarifas entre concessionárias são muito próximas.

O enfoque aqui tratado é dirigido para o "gás natural" como insumo energético, portanto serão apresentadas as tarifas para o "gás natural" e as tarifas de eletricidade. 


\subsubsection{Tarifas de gás natural}

As tarifas de gás natural praticadas atualmente no mercado sinalizam vantagens muito acentuadas para os "Grandes" consumidores, tanto para os usos comuns como nas tarifas diferenciadas para cogeração e geração termoelétrica, neste caso as tarifas reduzidas se aplicam apenas a consumos superiores a $500.000 \mathrm{~m}^{3} / \mathrm{mês}$.

A Portaria CSPE - 124, de 25 de maio de $2001{ }^{[5]}$ dispõem sobre os níveis tarifários, classificação em segmentos e enquadramento das classes de tarifas praticadas pela Concessionária de distribuição de gás canalizado na área de concessão Noroeste e demais providências pertinentes

Tabela 12 - Tarifas do gás natural

\section{TARIFAS DO GÁS NATURAL CANALIZADO Área de Concessão da COMGÁS}

\begin{tabular}{|c|c|c|c|c|}
\hline \multirow{3}{*}{ SEGMENTOS } & \multirow{3}{*}{ CLASSES } & \multirow{3}{*}{ VOLUMES MENSAIS } & \multicolumn{2}{|c|}{ TERMO } \\
\hline & & & FIXO - F & VARIÁVEL - V \\
\hline & & & em $\mathrm{R} \$$ & em $\mathrm{R} \$ / \mathrm{m} 3$ \\
\hline \multirow{8}{*}{$\begin{array}{c}\text { RESIDENCIAL } \\
\text { COMERCIAL } \\
\text { E } \\
\text { INDUSTRIAL }\end{array}$} & 1 & Até $5 \mathrm{~m} 3$ & 8,40 & 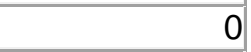 \\
\hline & 2 & 6 a $50 \mathrm{~m} 3$ & 0,85 & 1,601816 \\
\hline & 3 & 51 a $130 \mathrm{~m} 3$ & 13,54 & 1,351975 \\
\hline & 4 & 131 a $1.000 \mathrm{~m} 3$ & 63,71 & 0,969374 \\
\hline & 5 & 1.001 a $5.000 \mathrm{~m} 3$ & 117,56 & 0,915362 \\
\hline & 6 & 5.001 a $50.000 \mathrm{~m} 3$ & $1.795,15$ & 0,579890 \\
\hline & 7 & 50.001 a $300.000 \mathrm{~m} 3$ & $9.463,19$ & 0,426525 \\
\hline & 8 & 300.001 a $500.000 \mathrm{~m} 3$ & $23.638,34$ & 0,379278 \\
\hline \multirow{2}{*}{$\begin{array}{l}\text { GRANDES } \\
\text { USUÁRIOS }\end{array}$} & 9 & 500.001 a $1.000 .000 \mathrm{~m} 3$ & $24.299,71$ & 0,377953 \\
\hline & 10 & Acima de $1.000 .000 \mathrm{~m} 3$ & $26.167,23$ & 0,376086 \\
\hline GÁS NATURAL VEICULAR & GNV & & 0,00 & 0,226124 \\
\hline INTERRUPTÍVEL & IN & & 0,00 & 0,323743 \\
\hline
\end{tabular}

\section{Notas:}

1) Os valores não incluem ICMS

2) Valores para Gás Natural referido nas seguintes condições:

Poder Calorífico Superior $=9.400 \mathrm{kcal} / \mathrm{m} 3$

Temperatura $=293,150 \mathrm{~K}$

Pressão $=101.325 \mathrm{~Pa}$

3) Fórmula de Cálculo do Importe : I = F + (CM x V), onde

$\mathrm{F}=$ Valor do Termo Fixo

$\mathrm{CM}=$ Consumo Mensal Medido em m3

$\mathrm{V}=$ Valor do Termo Variável 


\section{ANEXO 2 \\ TARIFAS DO GÁS NATURAL CANALIZADO}

Área de Concessão da COMGÁs

DESCONTOS PARA O VALE DO PARAÍBA

Tabela 13 - Tarifas do gás natural

\begin{tabular}{|c|c|c|c|c|c|c|}
\hline \multirow{3}{*}{ SEGMENTOS } & \multirow{3}{*}{ CLASSES } & \multirow{3}{*}{$\begin{array}{l}\text { VOLUMES } \\
\text { MENSAIS }\end{array}$} & \multicolumn{4}{|c|}{ TERMO } \\
\hline & & & \multirow[t]{2}{*}{ FIXO - F } & \multirow{2}{*}{$\mathrm{Em} \mathrm{R} \$$} & $\begin{array}{c}\text { VARIÁVEL } \\
-\mathrm{F}\end{array}$ & $\begin{array}{c}\text { DESCONTO } \\
-\mathrm{dV}\end{array}$ \\
\hline & & & & & \multicolumn{2}{|c|}{$\mathrm{Em} \mathrm{R} \$ / \mathrm{m} 3$} \\
\hline \multirow{8}{*}{$\begin{array}{c}\text { RESIDENCIAL } \\
\text { COMERCIAL } \\
\text { E } \\
\text { INDUSTRIAL }\end{array}$} & 1 & Até $5 \mathrm{~m} 3$ & 8,40 & 1,45 & 0,00 & 0,00 \\
\hline & 2 & 6 a $50 \mathrm{~m} 3$ & 0,85 & 0,66 & 1,601816 & 0,311015 \\
\hline & 3 & 51 a $130 \mathrm{~m} 3$ & 13,54 & 10,50 & 1,351975 & 0,117322 \\
\hline & 4 & $\begin{array}{c}131 \text { a } 1.000 \\
\text { m3 }\end{array}$ & 63,71 & 9,45 & 0,969374 & 0,125613 \\
\hline & 5 & $\begin{array}{c}1.001 \mathrm{a} \\
5.000 \mathrm{~m} 3\end{array}$ & 117,56 & 17,43 & 0,915362 & 0,117605 \\
\hline & 6 & $\begin{array}{c}5.001 \mathrm{a} \\
50.000 \mathrm{~m} 3\end{array}$ & $1.795,15$ & 266,16 & 0,579890 & 0,067865 \\
\hline & 7 & $\begin{array}{c}50.001 \mathrm{a} \\
300.000 \mathrm{~m} 3\end{array}$ & $9.463,19$ & $1.402,91$ & 0,426525 & 0,045128 \\
\hline & 8 & $\begin{array}{c}300.001 \mathrm{a} \\
500.000 \mathrm{~m} 3\end{array}$ & $23.638,34$ & $3.503,62$ & 0,379278 & 0,038126 \\
\hline \multirow{2}{*}{$\begin{array}{l}\text { GRANDES } \\
\text { USUÁRIOS }\end{array}$} & 9 & $\begin{array}{c}500.001 \mathrm{a} \\
1.000 .000 \\
\mathrm{~m} 3\end{array}$ & $24.299,71$ & $3.604,27$ & 0,377953 & 0,037925 \\
\hline & 10 & $\begin{array}{c}\text { Acima de } \\
1.000 .000 \\
\mathrm{~m} 3\end{array}$ & $26.167,23$ & $3.885,69$ & 0,376086 & 0,037644 \\
\hline
\end{tabular}

Notas:

1) Os valores não incluem ICMS

2) Valores para Gás Natural referido nas seguintes condições:

Poder Calorífico Superior $=9.400 \mathrm{kcal} / \mathrm{m} 3$

Temperatura $=293,15^{\circ} \mathrm{K}$

Pressão $=101.325 \mathrm{~Pa}$

3) Fórmula de Cálculo do Importe : I = $(F-d F)+[C M \times(V-d V)]$, onde

$F=$ Valor do Termo Fixo

$\mathrm{dF}=$ Desconto sobre o Termo Fixo

$\mathrm{CM}=$ Consumo Mensal Medido em m3

$\mathrm{V}=$ Valor do Termo Variável

$\mathrm{dV}=$ Desconto sobre o Termo Variável 
ANEXO 3 - Portaria CSPE № 124

TABELA DE MARGENS MÁXIMAS

\section{Área de Concessão da COMGÁS \\ SEGMENTOS COGERAÇÃO E TERMOELÉTRICAS}

Tabela 14 - Tarifas do gás natural

\begin{tabular}{|c|c|r|}
\hline CLASSES & VOLUMES MENSAIS & VALOR DA MARGEM R $\$ / \mathrm{m} 3$ \\
\hline 1 & 0 a $2.000 .000 \mathrm{~m} 3$ & 0,0419644 \\
\hline 2 & $2.000 .001 \mathrm{a} 4.000 .000 \mathrm{~m} 3$ & 0,0373016 \\
\hline 3 & $4.000 .001 \mathrm{a} 7.000 .000 \mathrm{~m} 3$ & 0,0326390 \\
\hline 4 & $7.000 .001 \mathrm{a} 10.000 .000 \mathrm{~m} 3$ & 0,0279762 \\
\hline 5 & $10.000 .001 \mathrm{a} 20.000 .000 \mathrm{~m} 3$ & 0,0233136 \\
\hline 6 & Acima de $20.000 .000 \mathrm{~m} 3$ & 0,0093254 \\
\hline
\end{tabular}

Notas:

1) Os valores não incluem ICMS

2) Aplica-se para consumos mensais superiores a $500.000 \mathrm{m3}$. Consumos inferiores a $500.000 \mathrm{~m} 3$ mensais regulamentados pela Portaria CSPE-139 de 30 de agosto de 2001.

3) Ao valor das margens desta tabela, que já incluem os impostos PIS/COFINS, deverá ser acrescido o valor do preço médio ponderado dos contratos de suprimento de gás referido nas condições abaixo e destinados a esses segmentos.

4) Gás Natural referido nas seguintes condições:

Poder Calorífico Superior $=9.400 \mathrm{kcal} / \mathrm{m} 3$

Temperatura $=293,15^{\circ} \mathrm{K}$

Pressão $=101.325 \mathrm{~Pa}$

* 5) O custo médio ponderado do preço dos contratos de suprimento do gás canalizado e do transporte destinados a estes segmentos, já considerados os valores dos tributos PIS e COFINS incidentes no fornecimento pela Concessionária, vigentes nesta data, é de:

a. $R \$ 0,317422 / \mathrm{m}^{3}$, nos casos em que o gás canalizado é adquirido como insumo energético (matéria-prima) utilizado na geração ou co-geração de energia elétrica destinada à revenda a distribuidor.

b. $R \$ 0,319070 / \mathrm{m}^{3}$, nos casos em que o gás canalizado é adquirido como insumo energético (matéria-prima) utilizado na geração ou co-geração de energia elétrica destinada ao consumo próprio ou à venda a consumidor final.

Nesses valores já está considerado o valor dos tributos PIS e COFINS incidentes no fornecimento pela concessionária.

6) Os valores obtidos em razão de alterações para mais ou menos do custo médio ponderado, indicados no item 5 , serão contabilizados em separado por usuário e a este repassados, nos termos da Cláusula 11a do Contrato de Concessão.

7) O cálculo das margens deve ser aplicado em cascata, ou seja, progressivamente em cada uma das faixas de consumo.

* Valores alterados (de $R \$ 0,290601 / \mathrm{m}^{3}$ para $R \$ 0,317422 / \mathrm{m}^{3}$, e de $R \$$ $0,292110 / \mathrm{m}^{3}$ para $\mathrm{R} \$ 0,319070 / \mathrm{m}^{3}$ ) pela Portaria CSPE - 136 , de 10-8-2001. 


\subsubsection{Tarifas de eletricidade}

As tarifas de energia elétrica praticadas pelo mercado, apresentam variações muito acentuadas de preços para os diferentes grupos de consumidores, como se pode observar no quadro seguinte.

Os preços praticados para os grandes consumidores (Subgrupos A1 e A2) são iguais ou inferiores aos custos da energia comprada nos contratos iniciais do "MAE", enquanto que para os pequenos consumidores (Subgrupo A4) e os de baixa tensão (Grupo B) estão muito acima.

Outros aspectos a serem observados são os valores elevados de tarifas de emergência para os autoprodutores, que influem no custo operacional das empresas que produzem energia para uso próprio, como é o caso da maioria dos cogeradores.

As tarifas estão desequalizadas, e cada concessionária de distribuição tem preços diferenciados, porém não muito diferentes. Para efeito de cálculo, foram consideradas como exemplo as tarifas da Bandeirante Energia S.A. ${ }^{[6]}$ 
RESOLUÇÃO N o 409 da ANEEL de 20/10/2000 ( Anexo I ) - D.O.U. de 23/10/2000 [6]

Tabela 15 - Tarifas de eletricidade

\begin{tabular}{|c|c|c|c|c|c|c|c|c|c|c|}
\hline \multirow[t]{2}{*}{$\begin{array}{c}\text { GRUPO " A " } \\
\text { MÉDIA E ALTA TENSÃO }\end{array}$} & \multicolumn{2}{|c|}{ Subgrupo AS } & \multicolumn{2}{|c|}{$\begin{array}{l}\text { Subgrupo A1 } \\
230 \mathrm{kV} \text { ou mais }\end{array}$} & \multicolumn{2}{|c|}{$\begin{array}{c}\text { Subgrupo A2 } \\
88 \mathrm{kV} \text { a } 138 \mathrm{kV}\end{array}$} & \multicolumn{2}{|c|}{$\begin{array}{c}\text { Subgrupo A3a } \\
40 \mathrm{kV} \text { a } 44 \mathrm{kV}\end{array}$} & \multicolumn{2}{|c|}{$\begin{array}{l}\text { Subgrupo A4 } \\
2,3 \mathrm{kV} \text { a } 25 \mathrm{kV}\end{array}$} \\
\hline & $\begin{array}{l}\text { DEMANDA } \\
\mathrm{R} \$ / \mathrm{kW}\end{array}$ & $\begin{array}{l}\text { CONSUMO } \\
\mathrm{R} \$ / \mathrm{MWh}\end{array}$ & $\begin{array}{l}\text { DEMANDA } \\
\mathrm{R} \$ / \mathrm{kW}\end{array}$ & $\begin{array}{l}\text { CONSUMO } \\
\mathrm{R} \$ / \mathrm{MWh}\end{array}$ & \begin{tabular}{|c|} 
DEMANDA \\
$\mathrm{R} \$ / \mathrm{kW}$
\end{tabular} & $\begin{array}{l}\text { CONSUMO } \\
\mathrm{R} \$ / \mathrm{MWh}\end{array}$ & $\begin{array}{l}\text { DEMANDA } \\
\mathrm{R} \$ / \mathrm{kW}\end{array}$ & $\begin{array}{l}\text { CONSUMO } \\
\mathrm{R} \$ / \mathrm{MWh}\end{array}$ & $\begin{array}{c}\text { DEMANDA } \\
\mathrm{R} \$ / \mathrm{kW}\end{array}$ & $\begin{array}{l}\text { CONSUMO } \\
\mathrm{R} \$ / \mathrm{MWh}\end{array}$ \\
\hline SEGMENTO CONVENCIONAL & 10,38 & 107,94 & & & & & 6,80 & 99,47 & 6,99 & 102,39 \\
\hline & & & & & & & & & & \\
\hline \multicolumn{11}{|l|}{ SEGMENTO HORO-SAZONAL } \\
\hline \multicolumn{11}{|l|}{ TARIFA AZUL } \\
\hline PONTA SECA & 19,48 & 127,78 & 10,66 & 60,65 & 11,46 & 64,28 & 17,93 & 117,76 & 18,63 & 122,11 \\
\hline PONTA ÚMIDA & 19,48 & 118,25 & 10,66 & 53,05 & 11,46 & 59,96 & 17,93 & 109,91 & 18,63 & 113,00 \\
\hline FORA DE PONTA SECA & 9,53 & 60,77 & 2,23 & 42,91 & 2,66 & 46,06 & 6,01 & 56,01 & 6,21 & 58,06 \\
\hline FORA DE PONTA ÚMIDA & 9,53 & 53,69 & 2,23 & 36,47 & 2,66 & 42,25 & 6,01 & 49,48 & 6,21 & 51,30 \\
\hline \multicolumn{11}{|l|}{ ULTRAPASSAGEM } \\
\hline PONTA SECA / ÚMIDA & 58,44 & & 39,50 & & 42,42 & & 60,42 & & 55,85 & \\
\hline $\begin{array}{l}\text { FORA DE PONTA SECA / } \\
\text { ÚMIDA }\end{array}$ & 28,54 & & 8,28 & & 9,69 & & 20,13 & & 18,63 & \\
\hline \multicolumn{11}{|l|}{ TARIFA VERDE } \\
\hline PONTA SECA & 9,53 & 578,21 & & & & & 6,01 & 532,95 & 6,21 & 552,54 \\
\hline PONTA ÚMIDA & 9,53 & 568,74 & & & & & 6,01 & 524,19 & 6,21 & 543,47 \\
\hline FORA DE PONTA SECA & 9,53 & 60,77 & & & & & 6,01 & 56,01 & 6,21 & 58,06 \\
\hline FORA DE PONTA ÚMIDA & 9,53 & 53,69 & & & & & 6,01 & 49,48 & 6,21 & 51,30 \\
\hline \multicolumn{11}{|l|}{ ULTRAPASSAGEM } \\
\hline SECA / ÚMIDA & 28,54 & & & & & & 20,13 & & 18,63 & \\
\hline & & & & & & & & & & \\
\hline Tarifa de Emergência & DEMANDA & CONSUMO & \multirow{2}{*}{\multicolumn{4}{|c|}{$\begin{array}{c}\text { Descontos - Grupo A } \\
\text { (Exceto nas Tarifas de Ultrapassagem) }\end{array}$}} & & & & \\
\hline Autoprodutor & $\mathrm{R} \$ / \mathrm{kW} . \mathrm{Ano}$ & $\mathrm{R} \$ / \mathrm{MWh}$ & & & & & & & & \\
\hline $\mathrm{A} 2$ & 43,56 & 191,25 & \multicolumn{4}{|c|}{ Rural $\quad-10 \%$} & & & & \\
\hline A3 & 44,64 & 268,82 & \multirow{2}{*}{\multicolumn{4}{|c|}{$\begin{array}{lll}\text { Cooperativa de Eletrificação Rural } & - & 50 \% \\
\text { Água, Esgoto e Saneamento } & - & 15 \% \\
\end{array}$}} & & & & \\
\hline A3a CONVENCIONAL & & & & & & & & & & \\
\hline A3a HORO-SAZONAL AZUL & 50,58 & 281,51 & \multirow{2}{*}{\multicolumn{4}{|c|}{ Descontos Especiais - Grupo A }} & & & & \\
\hline A3a HORO-SAZONAL VERDE & 12,64 & 281,51 & & & & & & & & \\
\hline A4 CONVENCIONAL & & & \multirow{2}{*}{\multicolumn{4}{|c|}{$\begin{array}{lcc}\text { Rural Irrigação } & - & 70 \% \\
\text { Cooperativa de Eletrificação Rural Irrigada }- & 70 \% \\
\end{array}$}} & & & & \\
\hline A4 HORO-SAZONAL AZUL & 46,76 & 260,38 & & & & & & & & \\
\hline A4a HORO-SAZONAL VERDE & 11,68 & 260,30 & \multicolumn{4}{|c|}{ Portaria No 105 de 3/4/92 } & & & & \\
\hline
\end{tabular}




\subsection{Preços dos equipamentos}

A cogeração ou a geração termoelétrica na maioria dos casos necessita um investimento inicial menor por $\mathrm{kW}$ instalado comparado com a hidroeletricidade. Esta comparação é importante pois apesar do parque de geração de eletricidade instalado no Brasil ser eminentemente hidráulico a tendência é que a expansão se dê através da geração térmica.

\begin{tabular}{|l|c|}
\hline \multicolumn{1}{|c|}{ Processos } & Investimento por kW \\
\hline Cogeração ou Termoelétrica & US $\$ 800-1.000$ \\
\hline Hidroeletricidade & US $\$ 2.000-2.500$ \\
\hline
\end{tabular}

Tabela 16 - Preço de Caldeira - Combustível Líquidos/Gasosos (US\$) *

\begin{tabular}{|c|c|c|c|}
\hline $\begin{array}{c}\text { Vazão } \\
(\mathrm{t} / \mathrm{h})\end{array}$ & Saturado & \multicolumn{3}{|c|}{$\begin{array}{c}\text { Vapor } \\
21 \mathrm{kgf} / \mathrm{cm}^{2}\end{array}$} & $42 \mathrm{~kg} / \mathrm{cm}^{2}$ \\
\hline 7 & 531.000 & 657.400 & \\
\hline 10 & 609.540 & 761.200 & \\
\hline 15 & 649.570 & 830.400 & \\
\hline 20 & 689.600 & 899.600 & 1.384 .000 \\
\hline 25 & 720.460 & 955.000 & 1.501 .600 \\
\hline 30 & 751.230 & 1.003 .400 & 1.612 .400 \\
\hline 35 & 782.000 & 1.038 .000 & 1.730 .000 \\
\hline 55 & 1.518700 & & 2.076 .000 \\
\hline 70 & 1.741 .060 & & 2.352 .800 \\
\hline 90 & 1.960 .190 & & 2.629 .600 \\
\hline 110 & 2.233 .550 & & 2.975 .600 \\
\hline
\end{tabular}

* Dados para referência obtidos junto a fabricantes 
Tabela 17 - Preços de Equipamentos para Reforma de Caldeira (US\$) * Superaquecedor, Bomba e Acessórios

\begin{tabular}{|c|c|c|}
\hline $\begin{array}{c}\text { Vazão } \\
(\mathrm{t} / \mathrm{h})\end{array}$ & \multicolumn{2}{|c|}{$\begin{array}{c}\text { Vapor } \\
\text { Superaquecido }\end{array}$} \\
\hline 7 & $21 \mathrm{kgf} / \mathrm{cm}^{2}$ & $42 \mathrm{kgf} / \mathrm{cm}^{2}$ \\
\hline 10 & 29.760 & 44.980 \\
\hline 15 & 40.140 & 57.440 \\
\hline 20 & 60.200 & 86.500 \\
\hline 25 & 80.270 & 137.020 \\
\hline 30 & 89.270 & 152.700 \\
\hline 35 & 98.260 & 168.390 \\
\hline 55 & 107.260 & 184.070 \\
\hline 70 & 157.780 & 262.960 \\
\hline 90 & 166.080 & 276.800 \\
\hline 110 & 176.460 & 294.100 \\
\hline
\end{tabular}

* Dados para referência obtidos junto a fabricantes

Tabela 18 - Preços de Turbinas a Vapor

\begin{tabular}{|l|l|l|}
\hline \multicolumn{2}{|c|}{ Turbinas a Vapor } \\
\hline Tipo & $\underline{\text { Preço US } \$ / \mathrm{kW}}$ & Observações \\
\hline Simples Estágio & 240 & Potência instalada até $1.000 \mathrm{~kW}$ \\
\hline & 215 & Potência instalada entre 1.000 e $2.000 \mathrm{~kW}$ \\
\hline Múltiplos Estágios & 300 & Potência instalada até $2.000 \mathrm{~kW}$ \\
\hline & 290 & Potência instalada entre 2.000 e $4.000 \mathrm{~kW}$ \\
\hline & 267 & Potência instalada entre 4.000 e $6.000 \mathrm{~kW}$ \\
\hline & 233 & Potência instalada acima de $6.000 \mathrm{~kW}$ \\
\hline
\end{tabular}

Tabela 19 - Preços de Turbinas a Gás

\begin{tabular}{|c|c|}
\hline \multicolumn{2}{|c|}{ Turbinas a Gás } \\
\hline Faixa de Potência & Preço US\$ $/ \mathrm{kW}$ \\
\hline Até $1.000 \mathrm{~kW}$ & 794 \\
\hline De 1.001 a $2.000 \mathrm{~kW}$ & 666 \\
\hline De 2.001 a $5.000 \mathrm{~kW}$ & 438 \\
\hline De 5.001 a $10.000 \mathrm{~kW}$ & 420 \\
\hline De 10.001 a $20.000 \mathrm{~kW}$ & 417 \\
\hline De 20.001 a $30.000 \mathrm{~kW}$ & 341 \\
\hline De 30.001 a $50.000 \mathrm{~kW}$ & 297 \\
\hline De 50.001 a $100.000 \mathrm{~kW}$ & 255 \\
\hline Acima de $100.000 \mathrm{~kW}$ & 190 \\
\hline
\end{tabular}

Obs. : Estes valores são referentes ao país de origem dos equipamentos. 
Tabela 20 - Preços de Absorvedores

\begin{tabular}{|l|c|}
\hline \multicolumn{1}{|c|}{ Tipo } & US\$/T.R. \\
\hline Simples estágio & De 500 a 600 \\
\hline Múltiplos estágios & De 600 a 700 \\
\hline
\end{tabular}

\subsection{Despesas operacionais}

O custo de operação dos sistemas de geração em termoelétrica ou em cogeração, depende principalmente do custo do combustível utilizado, que é função do rendimento global das instalações.

Outro custo operacional, geralmente menor que o de combustível são as despesas de mão de obra realizadas com operador dos equipamentos.

Os equipamentos do sistema de cogeração exigem uma manutenção simples, porém cuidadosa. Para esse estudo recomenda-se adotar o valor de $2 \%$ ao ano sobre o investimento do respectivo equipamento.

\subsection{Impostos e taxas}

Os impostos e taxas dos empreendimentos de geração em termoelétrica ou cogeração são bastante significativos, chegando em alguns casos ser o maior custo do empreendimento. Sobre a receita bruta incidem PIS COFINS (3,65 \%), Imposto de Renda (33\%), Taxa da Aneel (0,5\% do valor econômico do empreendimento $=R \$ 150,48 / \mathrm{kWmês})$.

Além disso deve ser considerado nos cálculos econômicos e financeiros o custo do capital investido, ou seja, as taxas de juros praticadas no mercado $(\cong 18 \%$ aa $)$. 


\subsection{Análise econômica e financeira}

Para realizar a análise econômica e financeira dos projetos de cogeração é necessário reunir as seguintes informações:

a) Investimento - Valor total aplicado no projeto para geração de energia;

$\mathrm{I}=\mathrm{R} \$$

b) Receita - a receita será estabelecida valorando a energia útil produzida. No caso da cogeração deve ser atribuído valor a energia térmica utilizada no processo produtivo, mais a energia elétrica utilizada, e mais a energia elétrica excedente para venda. Para geração em termoelétrica será considerada a energia elétrica disponível para venda.

$E=R \$ / m e ̂ s$

$E=(E t \times P t)+($ Eec $\times$ Tee $)+($ Eev $\times$ Pve $)$

Onde:

Et $=$ Energia térmica utilizada no processo produtivo (vapor ou calor de processo);

$\mathrm{Pt}=$ Valor da energia térmica em $\mathrm{R} \$$ / unidade da energia térmica;

Eec $=$ Energia elétrica consumida pelo processo produtivo $\mathrm{MWh}$

Tee $=$ Tarifa de energia elétrica da unidade consumidora $\mathrm{R} \$ / \mathrm{MWh}$

Eev $=$ Energia elétrica vendida ao sistema MWh

Pev $=$ Preço obtido na venda do excedente de eletricidade $R \$ / M W h$ 
c) Despesas operacionais - são consideradas como despesas operacionais os gastos com combustíveis, operação e manutenção do sistema, e no caso de venda de eletricidade excedente é ainda considerada como despesa operacional o valor pago a titulo de tarifa de transmissão;

$\mathrm{O} \& \mathrm{M}=\mathrm{R} \$ / \mathrm{mês}$

$O \& M=(C c \times T c)+O+M+(P t p \times T t p)+(P t f p \times T t f p)$

$\mathrm{O} \& \mathrm{M}=(\mathrm{Cc} \times \mathrm{Tc})+\mathrm{O}+\mathrm{M}+\mathrm{Dt}$

$D t=(P t p \times T t p)+(P t f p \times T t f p)$

Onde:

$\mathrm{Cc}=$ Consumo mensal de combustível ( $\mathrm{t} / \mathrm{mês}$ ou $\mathrm{m}^{3} / \mathrm{mês}$ )

Tc = Preço do combustível ( $\mathrm{R} \$ /$ unidade comercial)

$\mathrm{O}=$ Despesas para operar o sistema de geração, estão inclusos neste item: o salário do operador, despesas com lubrificantes e materiais consumíveis $(\mathrm{R} \$ /$ mês $)$

$M=$ Custo de manutenção do sistema de geração, incluindo mão de obra e reposição de peças, normalmente se destina a manutenção $2 \%$ do investimento total por mês ( $\mathrm{R} \$ / \mathrm{mês})$

Ptp = Potência elétrica transmitida para venda no horário de ponta $(\mathrm{kW})$

Ttp = Tarifa de transmissão na ponta $(\mathrm{R} \$ / \mathrm{kW})$

Ptfp = Potência elétrica transmitida para venda no horário fora de ponta $(\mathrm{kW})$

Ttfp = Tarifa de transmissão fora da ponta $(\mathrm{R} \$ / \mathrm{kW})$ 
d) Impostos - são considerados, a taxa de fiscalização da ANEEL, e todos os impostos pagos pela venda da eletricidade produzida, como PIS, COFINS, Imposto de Renda;

$\mathrm{I}=\mathrm{R} \$ / \mathrm{mês}$

$\mathrm{I}=\mathrm{IR}+\mathrm{PIS}+\mathrm{COFINS}+\mathrm{ANEEL}$

Onde:

- $\quad \mathrm{IR}=$ imposto de renda sobre a eletricidade vendida, é cobrado $33 \%$ sobre a receita da venda ( $\mathrm{R} \$ / \mathrm{mês})$;

- $\quad$ PIS + COFINS = Impostos Sociais, 3,68\% sobre a receita das vendas de eletricidade $(\mathrm{R} \$ / \mathrm{mês})$;

- $\quad$ ANEEL $=$ Taxa de fiscalização é igual a $0,5 \%$ do beneficio econômico do empreendimento ( $R \$ 150,48 / \mathrm{kW}$.mês), (R\$/mês);

e) Juros - são considerados os encargos financeiros (juros) sobre o capital investido.

$\mathrm{J}=\mathrm{R} \$ / \mathrm{mês}$

Com estes valores é possível elaborar uma planilha de cálculos para realizar a análise econômica e financeira do empreendimento, dessa forma pode-se elaborar simulações interessantes, variando-se os valores de receita (preço de 
venda de energia) para chegar-se ao ponto ideal de retorno do investimento a ser realizado.

Figura 15 - Exemplo de planilha de calculo Fluxo de Caixa do Projeto

\begin{tabular}{|c|c|c|c|}
\hline Mês & jan-01 & fev-01 & mar-01 \\
\hline Consumo Próprio (MWh/mês) & Eec & Eec & Eec \\
\hline Consumo de Energia Térmica (Unid./mês) & Et & Et & Et \\
\hline Receitas de EE Consumo Próprio & Eev*Pve & Eev*Pve & Eev*Pve \\
\hline Receita de ET & $\mathrm{Et} \mathrm{t}^{*} \mathrm{Pt}$ & $\mathrm{Et} \mathrm{t}^{*} \mathrm{Pt}$ & $\mathrm{Et}{ }^{*} \mathrm{Pt}$ \\
\hline Receitas das Vendas de EE & Eev*Pve & Eev*Pve & Eev*Pve \\
\hline Combustível & $\mathrm{Cc} * \mathrm{Tc}$ & $\mathrm{Cc} * \mathrm{Tc}$ & $\mathrm{Cc} * \mathrm{Tc}$ \\
\hline O\&M & $\mathrm{O}+\mathrm{M}$ & $\mathrm{O}+\mathrm{M}$ & $\mathrm{O}+\mathrm{M}$ \\
\hline Transmissão & $\mathrm{Dt}$ & Dt & Dt \\
\hline Custos Operacionais (R\$/mês) & O\&M & O\&M & O\&M \\
\hline Resultado Operacional & $\mathrm{R}=\mathrm{E}-\mathrm{O} \& \mathrm{M}$ & $\mathrm{R}=\mathrm{E}-\mathrm{O} \& \mathrm{M}$ & $\mathrm{R}=\mathrm{E}-\mathrm{O} \& \mathrm{M}$ \\
\hline ANEEL & $\mathrm{A}=(150,48 * \mathrm{Pe})^{\star} 0,05$ & $A=\left(150,48^{*} \mathrm{Pe}\right)^{\star} 0,05$ & $A=\left(150,48^{*} \mathrm{Pe}\right)^{\star} 0,05$ \\
\hline Imposto de Renda & $\mathrm{IR}=\mathrm{L}^{*} 0,33$ & $\mathrm{IR}=\mathrm{L}^{\star} 0,33$ & $\mathrm{IR}=\mathrm{L}^{\star} 0,33$ \\
\hline Resultado (R\$/mês) & $R=E-P-I R-A$ & $R=E-P-I R-A$ & $R=E-P-I R-A$ \\
\hline Depesas com Juros & $\mathrm{J}=(\operatorname{Inv} .-\mathrm{R}) \operatorname{taxa}$ & $\mathrm{J} 2=(\mathrm{J}-\mathrm{R})^{\star} \operatorname{taxa}$ & $\mathrm{J} 3=(\mathrm{J} 2-\mathrm{R})^{\star} \operatorname{taxa}$ \\
\hline Fluxo de Caixa do Projeto & F=lnv-R-J & F=lnv-R-J & F=Inv-R-J \\
\hline
\end{tabular}

\section{Caso Prático}

Neste capítulo será desenvolvida a análise comparativa entre dois casos de cogeração e um caso de geração através de termelétrica.

A geração termoelétrica será realizada através de ciclo combinado, utilizando-se turbinas a gás e turbinas a vapor dimensionadas de modo a otimizar a eficiência do conjunto de geração.

Existem conjuntos de equipamentos previamente montados pelos fabricantes, em função da potência elétrica que se deseja, são chamados de "pacotes comerciais". Será utilizado, no exemplo, um desses pacotes. 
Para efeito de comparação será considerada uma termoelétrica com potência em torno de $200 \mathrm{MW}$, apesar da maioria dos sistemas de cogeração não serem deste porte, a comparação aqui apresentada será através de casos possíveis de serem encontrados na prática. Plantas de termoelétrica abaixo desta potência têm eficiência global menor, além de apresentarem baixo índice de rentabilidade econômica. Já as plantas de cogeração apesar de menores apresentam altos índices de eficiência global.

Pode-se comparar como investimento, a construção de várias plantas de cogeração com uma planta de termoelétrica de grande porte.

\subsection{Termoelétrica}

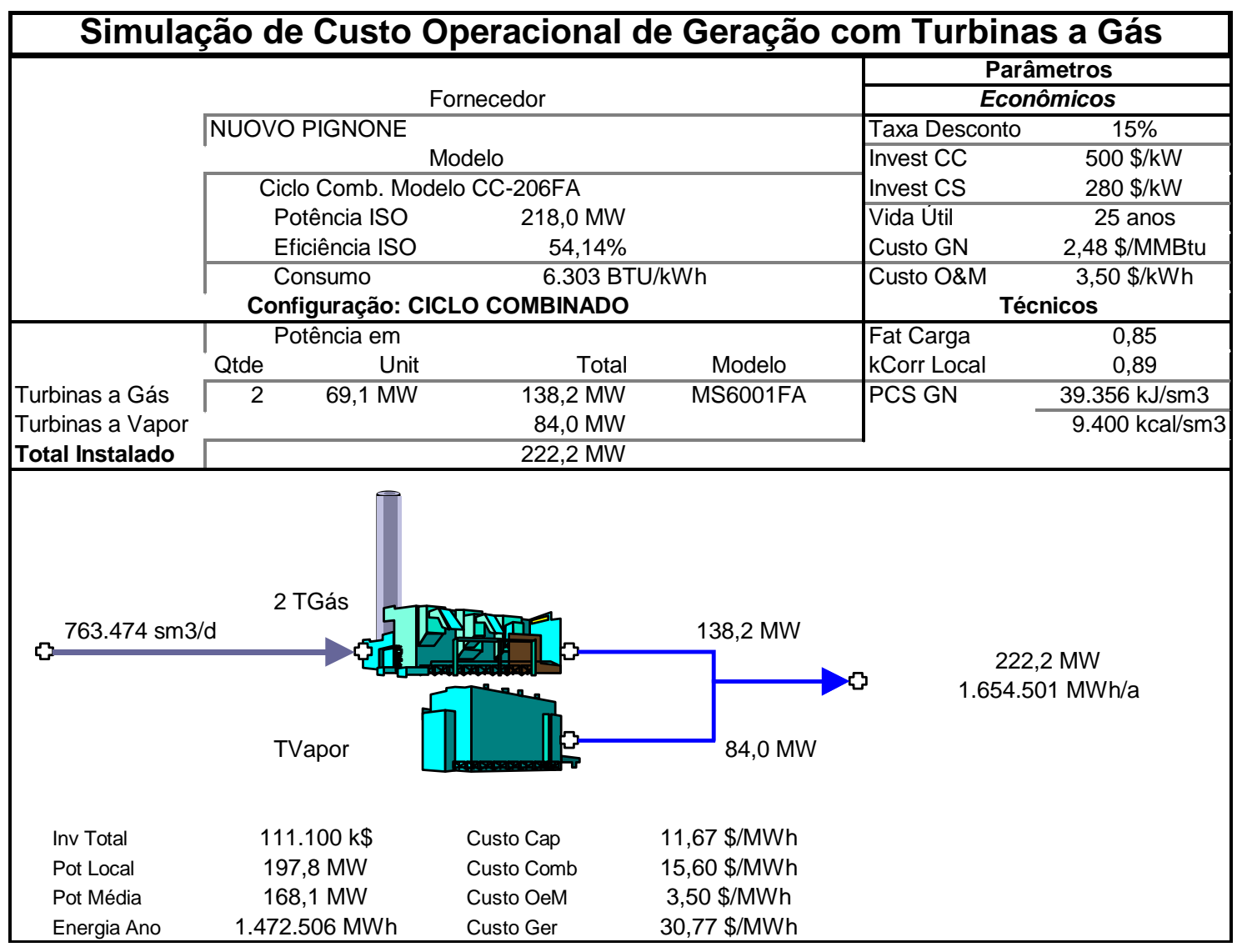




\subsection{Cogeração}

Um projeto de cogeração bem elaborado, onde se busca a otimização energética, geralmente segue os oito passos descritos a seguir:

\section{Balanço energético:}

Para elaborar um projeto de cogeração em uma unidade industrial, o primeiro passo é a realização do balanço energético da instalação, iniciando por levantamento dos dados sobre consumos dos energéticos.

\section{Levantamento dos dados de campo:}

Levantamento dos dados sobre o processo produtivo da indústria, como: necessidades térmicas, temperaturas utilizadas no processo, usos finais da eletricidade, etc.

\section{Diagnóstico energético:}

Realização de diagnóstico energético da instalação, com objetivo de identificar possibilidades de redução de desperdícios existentes e otimização do uso da energia nos processos produtivos. Com essa medida será obtida a real necessidade de energia.

\section{Seleção do tipo de cogeração:}

Realização de análise comparativa para identificar a forma de cogeração a ser instalada, Topping ou Bottoming, e qual o ciclo termodinâmico que melhor se adapta ao processo produtivo.

Com essas informações serão definidos os equipamentos que devem ser instalados. 


\section{Busca do cliente para o excedente de eletricidade:}

Havendo excedente de eletricidade produzido pela cogeração, deve-se analisar as condições de conexão ao sistema elétrico, e qual a melhor forma de comercialização da energia produzida.

\section{Projeto técnico e econômico:}

Realização dos projetos técnico, econômico e financeiro, verificando a viabilidade de instalação.

O projeto técnico abrange desde o dimensionamento dos equipamentos, procurando utilizar o máximo possível turbinas e geradores dos modelos padronizados pelos fabricantes, até o estudo do impacto ambiental da instalação.

O projeto econômico visa a análise dos custos envolvidos e das receitas produzidas, fazendo-se a comparação com a situação anterior.

O projeto financeiro visa a análise das fontes de recursos possíveis de serem utilizadas, buscando minimizar as taxas de juros no projeto.

\section{Consulta a órgãos governamentais:}

Consulta a ANEEL, e outros organismos governamentais, como orgãos ambientais, para iniciar os processos de legalização do empreendimento.Em paralelo deve-se iniciar as negociações com o comprador da energia excedente (se for o caso), e com o fornecedor da energia necessária ao processo de cogeração.

Instalação:

Instalação e operação dos equipamentos. 
A seguir será apresentado um caso prático de cogeração, no qual serão realizadas várias simulações, que levarão a conclusão deste trabalho, com a elaboração de diferentes cenários.

O primeiro caso será uma instalação com excedente de eletricidade para comercialização. O segundo, produzindo uma quantidade de eletricidade igual ou menor que a necessária ao processo produtivo da indústria hospedeira do sistema.

\subsubsection{Cogeração com eletricidade excedente}

Será considerada uma industria química que utiliza grande quantidade de vapor no processo produtivo.

\section{Balanço Energético}

A indústria do exemplo utiliza no seu processo de produção dois energéticos:

- Gás Natural: - utilizado para produção de vapor

- Eletricidade: utilizada principalmente para força motriz (85\%), iluminação (10\%), outros usos (5\%).

O processo necessita de 65 toneladas de vapor por hora, a pressão de 7 bar, e usa eletricidade registrando $30 \mathrm{MW}$ de demanda, e consome energia com fator de carga de $90 \%$, consumindo $19.710 \mathrm{MWh} / \mathrm{mês}$. 


\section{Energia Térmica Necessária}

$E \mathrm{t}=155.115 .297 \mathrm{~kJ} / \mathrm{h}$

Eficiência da caldeira $=91 \%$

\section{Consumo de Combustível}

$\mathrm{Cc}=(\mathrm{Et} / \mathrm{PCl}){ }^{*} \mathrm{r}$

Onde:

$r=$ rendimento da caldeira;

$\mathrm{PCl}=$ Poder calorífico Inferior do gás natural;

Et $=$ Energia necessária para produzir o vapor

$C v=4017,0248 \mathrm{~m} 3 / \mathrm{h}$ de gás natural

$\mathrm{Cv}=2.932 .428 \mathrm{~m} 3 / \mathrm{mês}$ de gás natural

\section{Diagnóstico energético}

Foi feito um levantamento detalhado das instalações, analisando o processo produtivo, condições dos equipamentos utilizados, adequando o uso dos energéticos às reais necessidades da indústria.

Será considerado aqui que os dados levantados no balanço energético que já se encontram otimizados.

\section{Escolha do sistema de cogeração}

Devido a necessidade do processo industrial, que utiliza grande volume de vapor saturado a baixa temperatura (pressão de 7 bar), a opção será por um sistema de cogeração que opera com ciclo Brayton, ou seja, uma turbina a gás 
para geração de eletricidade e uma caldeira de recuperação para produzir o vapor a partir dos gases de exaustão da turbina.

Será adotado um sistema comercialmente disponível no mercado, um pacote de turbo gerador a gás.

O dimensionamento será feito a partir da necessidade térmica, ou seja, todo o vapor necessário ao processo produtivo será obtido a partir do calor liberado na turbina a gás.

Será utilizado um turbo gerador Ge Power Systems Modelo LM600, cujas características técnicas são:

\begin{tabular}{|l|r|}
\hline Consumo & $8955 \mathrm{~kJ} / \mathrm{kWh}$ \\
\hline Rendimento & $40,20 \%$ \\
\hline Vazão de gás de combustão em massa & $448870 \mathrm{~kg} / \mathrm{h}$ \\
\hline Calor específico do gás de combustão & $1,039 \mathrm{~kJ} / \mathrm{kg}^{\circ} \mathrm{C}$ \\
\hline Temperatura de exaustão & $463^{\circ} \mathrm{C}$ \\
\hline $\begin{array}{l}\text { Energia elétrica produzida nas condições } \\
\text { ISO }\end{array}$ & $40 \mathrm{MWh}$ \\
\hline
\end{tabular}

\section{Energia contida no gás de exaustão}

$\mathrm{Eg}=\mathrm{m} \times \mathrm{Cp} \times \mathrm{t}$

$\mathrm{Eg}=215932056 \mathrm{~kJ} / \mathrm{h}$

Equivalente de gás $=\mathrm{Eg} / \mathrm{PCl}$

Consumo de combustível $=6145,05 \mathrm{~m} 3 / \mathrm{h}$ de gás natural

Consumo de combustível equivalente $=4.485 .887 \mathrm{~m} 3 / \mathrm{mês}$ de gás natural

\section{Consumo de gás natural pela turbina}

$\mathrm{Cc}=($ consumo específico da turbina $) \times($ energia elétrica produzida $)$ 
$\mathrm{Cc}=8.955 \times(40.000 \times 730)$

$\mathrm{Cc}=261.486 .000 .000 \mathrm{~kJ} / \mathrm{mês}$

$\mathrm{Cc}=7.441 .439,065 \mathrm{~m}^{3} / \mathrm{mês}$ de gás natural

\section{Calculo da eficiência global do sistema}

A eficiência global será dada pela relação direta entre a energia consumida (que entra) no sistema com a energia útil que é produzida (que sai) pelo sistema

Assim, temos:

Rendimento $=\frac{(\mathrm{Cv}+\mathrm{Eee})}{\mathrm{Cc}}$

$\mathrm{Cv}=$ Consumo de gás natural equivalente ao vapor produzido Eee $=$ Consumo de gás natural equivalente a eletricidade produzida $\mathrm{C} c=$ Consumo de gás natural da turbina

$\mathrm{Eee}=\frac{(40000 \times 730) 3.600}{3.5139,17}$

Eee $=2.991 .533,40 \mathrm{~m}^{3} / \mathrm{mês}$ de gás natural

Rendimento $=\frac{(2.932 .428+2.991 .533,40)}{7.441 .439,065}$ 
Rendimento $=79,6 \%$

\section{Investimento necessário}

- Custo do turbo gerador selecionado ( US\$250,00/kW, posto no Brasil ) $\operatorname{Ctg}=250,00 \times 40.000$

$\mathrm{Ctg}=\mathrm{US} \$ 10.000 .000,00$

- Custo da caldeira de recuperação para produzir $65.000 \mathrm{kgv} / \mathrm{h}$ a pressão de 7 bar

Ccr $=$ US $\$ 1.000 .000,00$

Custo dos acessórios e equipamentos complementares a geração elétrica e de vapor

$$
\mathrm{Ca}=\text { US } \$ 1.000 .000,00
$$

Custo das obras necessárias e montagens eletromecânicas

$$
\mathrm{Cm}=\mathrm{US} \$ 500.000,00
$$

Total $=$ US $\$ 12.500 .000,00$

\section{Despesas econômicas e financeiras do projeto}

Taxa de desconto (aa) $\left(^{*}\right)$

$12 \%$

Taxa de juros (aa) $\left({ }^{* *}\right)$

$16 \%$

Perdas Transmissão

$0,0 \%$

ICMS

$17 \%$

Custo do gás $\mathrm{R} \$ / \mathrm{m}^{3}$

0,3453982

PIS e COFINS

$3,65 \%$

Vida Útil (anos)

Câmbio (R\$/US\$)

2,70 
$\left(^{\star}\right)$ a Taxa de desconto é calculada sobre a parcela de capital próprio investido do projeto, neste caso será de $30 \%$ do total.

$\left.{ }^{* \star}\right)$ a Taxa de juros será devida aos $70 \%$ do investimento que foram captados no mercado financeiro.

\section{Receitas do projeto}

São consideradas receitas do projeto o valor recebido pela eletricidade excedente produzida, que será comercializada para terceiros, somado ás despesas atuais com eletricidade, descontando-se o acréscimo de despesa com gás natural, comparado com a situação anterior. A receita será expressa pela seguinte equação:

$R=$ Deea + Reev $-($ Dgnc - Dgna $)$

Onde:

Deea = Despesa com energia elétrica na situação atual;

Reev = Receita da venda de energia elétrica;

Dgnc = Despesa com gás natural do empreendimento de cogeração

Dgna = Despesa com gás natural na situação atual

\section{Cálculo da despesa atual com eletricidade:}

A indústria está sendo faturada pelo sistema tarifário horo sazonal azul, e pertence ao sub grupo de faturamento $\mathrm{A} 2$, onde as tarifas são: 
Demanda na ponta (TDp)

Demanda fora da ponta (TDfp)

Consumo na ponta no período seco (Tcps)

Consumo na ponta no período úmido (Tcpu)

Consumo fora da ponta no período seco (TCfps)

Consumo fora da ponta no período úmido (Tcfpu)
$11,46 \mathrm{R} \$ / \mathrm{kW}$

$2,66 \mathrm{R} \$ / \mathrm{kW}$

$64,28 \mathrm{R} \$ / \mathrm{MWh}$

$59,96 \mathrm{R} \$ / \mathrm{MWh}$

49,06 R\$/MWh

$42,25 \mathrm{R} \$ / \mathrm{MWh}$

As tarifas de consumo serão calculadas com a média ponderada ao longo do ano:

$\mathrm{TCp}=[(\mathrm{TCps} \times 7)=(\mathrm{TCpu} \times 5)] / 12$

$\mathrm{TCp}=62,48 \mathrm{R} \$ / \mathrm{MWh}$

$\operatorname{TCfp}=[($ TCfps $\times 7)=($ TCfpu $\times 5)] / 12$

$\mathrm{TCfp}=46,22 \mathrm{R} \$ / \mathrm{MWh}$

Será calculada uma conta média mensal para as condições específicas da industria do exemplo.

Deea $=(D p \times T D p)+$ Dfp $\times$ TDfp $)+(C p \times T C p)+(C f p \times T C f p)$

$\mathrm{Cp}=\mathrm{Dp} \times \mathrm{FCp} \times \mathrm{hp}$

Onde:

$\mathrm{Dp}=$ demanda de ponta $=30 \mathrm{MW}$

$\mathrm{FCp}=$ fator de carga na ponta $=0,9$

$\mathrm{hp}=$ numero de horas de ponta $=66$ horas $/$ mês

$\mathrm{Cp}=1782 \mathrm{MWh}$ 
Cfp $=$ Dfp $\times$ FCfp $\times$ hfp

Onde:

$\mathrm{Dfp}=$ demanda fora de ponta $=30 \mathrm{MW}$

$\mathrm{FCfp}=$ fator de carga fora da ponta $=0,9$

hfp $=$ numero de horas de ponta $=664$ horas $/$ mês

$\mathrm{Cfp}=17928 \mathrm{MWh}$

Portanto, Deea $=\mathrm{R} \$ 940.395,12 /$ mês

(obs: não foi considerado o ICMS porque é recuperado pela indústria)

Os valores de tarifa de comercialização do excedente serão variáveis de acordo com os diversos cenários apresentados neste capitulo.

\section{Análise econômica do projeto}

A analise econômica do projeto será feita através da construção de uma planilha de cálculos utilizando-se o software excel, conforme modelo apresentado no item 8.5

Os resultados dos cálculos dos parâmetros realizados nos itens anteriores mostram que o projeto escolhido como exemplo pode ser considerado um bom projeto técnico, as principais características são:

Rendimento global $=79,6 \%$

Investimento relativo $=\mathrm{R} \$ 843,75 / \mathrm{kW}$ 
Serão considerados para os cálculos econômicos os seguintes parâmetros:

- -Investimento: será financiado $70 \%$ do total a ser investido a uma taxa de $16 \%$ ao ano, e prazo de pagamento de dez anos. Os outros $30 \%$ será utilizado recurso próprio a uma taxa de desconto de $12 \%$ ao ano.

- Condições operacionais: a indústria normalmente paralisa suas atividades normalmente durante 10 dias por ano. Período em que se faz manutenção programada, e será coincidente com a manutenção da turbina. Durante a parada programada a energia elétrica necessária será desprezada, pois é muito pequena e pode ser suprida com geração de emergência a diesel.

- Condições de comercialização: a eletricidade excedente da geração será comercializada a $80 \%$ do valor do VN, e neste valor já se incluem os custos de conexão para o sistema, e o contrato com o comprador prevê o desligamento do sistema por dez dias, deve ser considerada apenas a compra de energia em situações de emergência. A seguir serão feitas simulações variando o valor de venda da eletricidade excedente,

- Situação de emergência: em caso de pane não prevista no sistema de geração de energia, a industria conseguiria operar em caráter de emergência com $40 \%$ da demanda fora da ponta e $30 \%$ da demanda no horário de ponta. Será previsto 264 horas durante o ano (3\%), que o sistema poderá ficar inoperante, como segurança operacional.

Estas premissas são validas para todas as situações de simulação que apresentamos a seguir. 


\section{Situação 1}

A situação 1 se refere a condição de venda de eletricidade excedente para a concessionária (ou consumidor livre) pela tarifa igual a $80 \%$ do $\mathrm{VN}$, ou seja, $\mathrm{R} \$ 64,05 / \mathrm{MWh}$, e considerando a tarifa de gás natural da CSPE atualmente aplicada a indústrias que pretendem implantar projetos de cogeração, $\mathrm{R} \$$ $0,345398 / \mathrm{m}^{3}$.

O quadro abaixo mostra que nestas condições, este projeto de cogeração, apesar de ser considerado um bom projeto, não é viável economicamente, pois o capital próprio investido não retorna antes do término da vida esperada do projeto (15 anos).

Fluxo de Caixa do Projeto

\begin{tabular}{|l|c|c|}
\hline \multicolumn{1}{|c|}{ Mês } & 1 & 2 \\
\hline \multicolumn{1}{|c|}{ Consumo Próprio (MWh/mês) } & 18.576 & 18.576 \\
\hline \multicolumn{1}{|c|}{ Consumo de Energia Térmica (m3./mês de gás) } & 2.771 .747 & 2.771 .747 \\
\hline \multicolumn{1}{|c|}{ Eletricidade Disponível (MWh/mês) } & 8.636 & 8.636 \\
\hline Receitas de EE Consumo Próprio (custo evitado) & $1.326 .213,40$ & $1.326 .213,40$ \\
\hline Receita de ET (custo evitado) & $957.356,42$ & $957.356,42$ \\
\hline Receitas das Vendas de EE & $553.135,80$ & $553.135,80$ \\
\hline RECEITA (R\$/mês) & $\mathbf{2 . 8 3 6 . 7 0 6}$ & $\mathbf{2 . 8 3 6 . 7 0 6}$ \\
\hline Combustível (R\$/mês) & $2.499 .841,58$ & $2.499 .841,58$ \\
\hline O\&M (R\$/Mês) & $200.750,00$ & $200.750,00$ \\
\hline Transmissão na ponta (R\$/mês) & $15.840,00$ & $15.840,00$ \\
\hline Transmissão fora da ponta (R\$/mês) & $1.080,00$ & $1.080,00$ \\
\hline Eletri. de emergência no MAE (R\$/mês) & $41.580,00$ & $41.580,00$ \\
\hline Custos Operacionais (R\$/mês) & $\mathbf{2 . 7 5 9 . 0 9 2}$ & $\mathbf{2 . 7 5 9 . 0 9 2}$ \\
\hline Resultado Operacional & $77.614,04$ & $77.614,04$ \\
\hline Resultado Operacional p/Impostos & $553.135,80$ & $553.135,80$ \\
\hline PIS/Cofins sobre Vendas (R\$/mês) & $20.355,40$ & $20.355,40$ \\
\hline Depreciação acelerada (R\$/mês) & $472.500,00$ & $472.500,00$ \\
\hline Lucro Tributável (Lucro antes IR) R\$/mês) & $-202.864,20$ & $-200.501,70$ \\
\hline ANEEL (R\$/mês) & $4.380,00$ & $4.380,00$ \\
\hline Imposto de Renda (R\$/mês) & $-73.662,47$ & $-72.882,84$ \\
\hline Resultado (R\$/mês) & $\mathbf{1 2 6 . 5 4 1 , 1 1}$ & $\mathbf{1 2 5 . 7 6 1 , 4 9}$ \\
\hline Investimento (capital próprio) (R\$) & $\mathbf{1 0 . 1 2 5 . 0 0 0 , 0 0}$ & $\mathbf{1 0 . 5 7 5 . 0 2 1 , 3 9}$ \\
\hline Investimento (recursos financiados) (R\$) & $\mathbf{2 3 . 6 2 5 . 0 0 0 , 0 0}$ & $\mathbf{2 3 . 4 2 8 . 1 2 5 , 0 0}$ \\
\hline Depesas com Juros (financiamento) (R\$/mês) & 283.500 & 281.138 \\
\hline Fluxo de Caixa do Projeto & $\mathbf{- 1 5 6 . 9 5 9}$ & $\mathbf{- 1 5 5 . 3 7 6}$ \\
\hline Amortização & $196.875,00$ & $196.875,00$ \\
\hline Amortização Financiamento (R\$/mÊS) & $\mathbf{- 3 5 3 . 8 3 3 , 8 9}$ & $\mathbf{- 3 5 2 . 2 5 1 , 0 1}$ \\
\hline Receita Liquida (R\$/mês) & & \\
\hline & & \\
\hline
\end{tabular}




\section{Situação 2}

A situação 2 se refere à condição de venda de eletricidade excedente para a concessionária (ou consumidor livre) pela tarifa igual a $85 \%$ do $\mathrm{VN}$, ou seja, $\mathrm{R} \$ 64,05 / \mathrm{MWh}$, e considerando a tarifa de gás natural igual á disponível na Portaria Interministerial n 176 de 01 de junho de 2001, válida para geração termoelétrica a gás natural a ser implantada até 30 de junho de 2.003.Esta tarifa é de US\$2,57 /MMBTU.

Desta forma o empreendimento pode ser considerado economicamente inviável pois a amortização do capital investido ocorre após 161 meses, tempo considerado longo demais, pois os equipamentos instalados apresentam vida estimada em 15 anos. 
Fluxo de Caixa do Projeto

\begin{tabular}{|c|c|c|c|c|}
\hline Mês & 1 & & 161 & 162 \\
\hline Consumo Próprio (MWh/mês) & 18.576 & \multirow{2}{*}{$\cdots$} & 18.576 & 18.576 \\
\hline Consumo de Energia Térmica (m3./mês de gás) & 2.771 .747 & & 2.771 .747 & 2.771 .747 \\
\hline Eletricidade Disponível (MWh/mês) & 8.636 & \multirow[b]{2}{*}{$\ldots$} & 8.636 & 8.636 \\
\hline Receitas de EE Consumo Próprio (custo evitado) & $1.326 .213,40$ & & $1.326 .213,40$ & $1.326 .213,40$ \\
\hline Receita de ET (custo evitado) & $733.850,51$ & \multirow{2}{*}{$\ldots$} & $733.850,51$ & $733.850,51$ \\
\hline Receitas das Vendas de EE & $553.135,80$ & & $553.135,80$ & $553.135,80$ \\
\hline RECEITA (R\$/mês) & 2.613 .200 & & 2.613 .200 & 2.613 .200 \\
\hline Combustível & $1.916 .224,68$ & & $1.916 .224,68$ & $1.916 .224,68$ \\
\hline O\&M & $200.750,00$ & & $200.750,00$ & $200.750,00$ \\
\hline Transmissão na ponta (R\$/mês) & $15.840,00$ & & $15.840,00$ & $15.840,00$ \\
\hline Transmissão fora da ponta (R\$/mês) & $1.080,00$ & \multirow{2}{*}{$\cdots$} & $1.080,00$ & $1.080,00$ \\
\hline Eletri. de emergência no MAE (R\$/mês) & $41.580,00$ & & $41.580,00$ & $41.580,00$ \\
\hline Custos Operacionais ( $\mathrm{R} \$ / \mathrm{mês}$ ) & 2.175 .475 & $\cdots$ & 2.175 .475 & 2.175 .475 \\
\hline Resultado Operacional & $437.725,02$ & & $437.725,02$ & $437.725,02$ \\
\hline Resultado Operacional p/ Impostos & $553.135,80$ & & $553.135,80$ & $553.135,80$ \\
\hline PIS/Cofins sobre Vendas & $20.355,40$ & & $20.355,40$ & $20.355,40$ \\
\hline Depreciação acelerada & $472.500,00$ & & $472.500,00$ & $472.500,00$ \\
\hline Lucro Tributável (Lucro antes IR) & $-202.864,20$ & & $80.635,80$ & $80.635,80$ \\
\hline ANEEL & $4.380,00$ & & $4.380,00$ & $4.380,00$ \\
\hline Imposto de Renda & $-73.662,47$ & & $19.892,53$ & $19.892,53$ \\
\hline Resultado (R\$/mês) & $486.652,09$ & $\ldots$ & $393.097,09$ & $393.097,09$ \\
\hline Investimento (capital próprio) & $10.125 .000,00$ & \multirow[t]{2}{*}{$\cdots$} & $75.121,80$ & 0,00 \\
\hline Investimento (recursos financiados) & $23.625 .000,00$ & & 0,00 & 0,00 \\
\hline Depesas com Juros (financiamento) & 283.500 & $\ldots$ & 0 & 0 \\
\hline Fluxo de Caixa do Projeto & 203.152 & $\ldots$ & 393.097 & 393.097 \\
\hline Amortização & & $\ldots$ & & \\
\hline Amortização Financiamento & $196.875,00$ & & 0,00 & 0,00 \\
\hline Receita Liquida & $6.277,09$ & & $393.097,09$ & $393.097,09$ \\
\hline
\end{tabular}

\subsubsection{Cogeração sem eletricidade excedente}

Para facilitar o efeito comparativo, será utilizado o mesmo caso prático, considerando-se que a indústria em questão consome toda a eletricidade produzida no empreendimento.

Todos os demais dados serão iguais, exceto o consumo de eletricidade e o valor envolvido, bem como não haverá imposto de renda e PIS e COFINS incidindo sobre a produção, pois não haverá venda de excedente.

A análise econômica demonstra o resultado. 


\section{Situação 1}

A situação 1 se refere à condição de tarifa de gás natural da CSPE atualmente aplicada a indústrias que pretendem implantar projetos de cogeração, $R \$$ $0,345398 / \mathrm{m}^{3}$.

O quadro abaixo mostra que nestas condições, este projeto de cogeração, apesar de ser considerado um bom projeto, não é viável economicamente, pois o capital próprio investido não retorna antes do término da vida esperada do projeto (15 anos).

\section{Fluxo de Caixa do Projeto}

\begin{tabular}{|l|c|c|}
\hline \multicolumn{1}{|c|}{ Mês } & 1 & 27.212 \\
\hline \multicolumn{1}{|c|}{ Consumo Próprio (MWh/mês) } & 2.771 .747 & 27.212 \\
\hline Receitas de EE Consumo Próprio (custo evitado) & $1.923 .666,65$ & $1.923 .666,65$ \\
\hline Receita de ET (custo evitado) & $957.356,42$ & $957.356,42$ \\
\hline RECEITA (R\$/mês) & $\mathbf{2 . 8 8 1 . 0 2 3}$ & $\mathbf{2 . 8 8 1 . 0 2 3}$ \\
\hline Combustível (R\$/mês) & $2.499 .841,58$ & $2.499 .841,58$ \\
\hline O\&M (R\$/mês) & $200.750,00$ & $200.750,00$ \\
\hline Transmissão na ponta (R\$/mês) & $15.840,00$ & $15.840,00$ \\
\hline Transmissão fora da ponta (R\$/mês) & $1.080,00$ & $1.080,00$ \\
\hline Eletri. de emergência no MAE (R\$/mês) & $41.580,00$ & $41.580,00$ \\
\hline Custos Operacionais (R\$/mês) & $\mathbf{2 . 7 5 9 . 0 9 2}$ & $\mathbf{2 . 7 5 9 . 0 9 2}$ \\
\hline Resultado Operacional (R\$/mês) & $121.931,50$ & $121.931,50$ \\
\hline ANEEL (R\$/mês) & $4.380,00$ & $4.380,00$ \\
\hline Resultado (R\$/mês) & $\mathbf{1 1 7 . 5 5 1 , 5 0}$ & $\mathbf{1 1 7 . 5 5 1 , 5 0}$ \\
\hline Investimento (capital próprio) (R\$) & $\mathbf{1 0 . 1 2 5 . 0 0 0 , 0 0}$ & $\mathbf{1 0 . 5 8 4 . 0 1 1 , 0 0}$ \\
\hline Investimento (recursos financiados) (R\$) & $\mathbf{2 3 . 6 2 5 . 0 0 0 , 0 0}$ & $\mathbf{2 3 . 4 2 8 . 1 2 5 , 0 0}$ \\
\hline Depesas com Juros (financiamento) (R\$/mês) & 283.500 & 281.138 \\
\hline Fluxo de Caixa do Projeto & $\mathbf{- 1 6 5 . 9 4 9}$ & $\mathbf{- 1 6 3 . 5 8 6}$ \\
\hline Amortização & \multicolumn{2}{|c|}{} \\
\hline Amortização Financiamento (R\$/mês) & $196.875,00$ & $196.875,00$ \\
\hline Receita Liquida (R\$/mês) & $\mathbf{- 3 6 2 . 8 2 3 , 5 0}$ & $\mathbf{- 3 6 0 . 4 6 1 , 0 0}$ \\
\hline
\end{tabular}




\section{Situação 2}

A situação 2 se refere à condição de tarifa de gás natural igual á disponível na Portaria Interministerial no 176 de 01 de junho de 2001, válida para geração termoelétrica a gás natural a ser implantada até 30 de junho de 2.003.Esta tarifa é de US\$2,57/MMBTU.

\section{Fluxo de Caixa do Projeto}

\begin{tabular}{|c|c|c|c|c|c|c|}
\hline Mês & 1 & 2 & 3 & $\ldots$ & 161 & 162 \\
\hline Consumo Próprio (MWh/mês) & 27.212 & 27.212 & 27.212 & \multirow{2}{*}{$\cdots$} & 27.212 & 27.212 \\
\hline Consumo de Energia Térmica (m3./mês de gás) & 2.771 .747 & 2.771 .747 & 2.771 .747 & & 2.771 .747 & 2.771 .747 \\
\hline Receitas de EE Consumo Próprio (custo evitado) & $1.923 .666,65$ & $1.923 .666,65$ & $1.923 .666,65$ & \multirow{3}{*}{$\cdots$} & $1.923 .666,65$ & $1.923 .666,65$ \\
\hline Receita de ET (custo evitado) & $733.850,51$ & $733.850,51$ & $733.850,51$ & & $733.850,51$ & $733.850,51$ \\
\hline RECEITA (R\$/mês) & 2.657 .517 & 2.657 .517 & 2.657 .517 & & 2.657 .517 & 2.657 .517 \\
\hline Combustível (R\$/mês) & $1.916 .224,68$ & $1.916 .224,68$ & $1.916 .224,68$ & \multirow[b]{2}{*}{$\ldots$} & $1.916 .224,68$ & $1.916 .224,68$ \\
\hline $\mathrm{O} \& \mathrm{M}(\mathrm{R} \$ / \mathrm{mês})$ & $200.750,00$ & $200.750,00$ & $200.750,00$ & & $200.750,00$ & $200.750,00$ \\
\hline Transmissão na ponta (R\$/mês) & $15.840,00$ & $15.840,00$ & $15.840,00$ & \multirow[b]{2}{*}{$\cdots$} & $15.840,00$ & $15.840,00$ \\
\hline Transmissão fora da ponta ( $\mathrm{R} \$ /$ mês) & $1.080,00$ & $1.080,00$ & $1.080,00$ & & $1.080,00$ & $1.080,00$ \\
\hline Eletri. de emergência no MAE (R\$/mês) & $41.580,00$ & $41.580,00$ & $41.580,00$ & & $41.580,00$ & $41.580,00$ \\
\hline Custos Operacionais ( $\mathrm{R} \$ / \mathrm{mês}$ ) & 2.175 .475 & 2.175 .475 & 2.175 .475 & & 2.175 .475 & 2.175 .475 \\
\hline Resultado Operacional (R\$/mês) & $482.042,48$ & $482.042,48$ & $482.042,48$ & \multirow[b]{2}{*}{$\cdots$} & $482.042,48$ & $482.042,48$ \\
\hline ANEEL (R\$/mês) & $4.380,00$ & $4.380,00$ & $4.380,00$ & & $4.380,00$ & $4.380,00$ \\
\hline Resultado (R\$/mês) & $477.662,48$ & $477.662,48$ & $477.662,48$ & \multirow{2}{*}{$\begin{array}{l}\cdots \\
\cdots\end{array}$} & $477.662,48$ & $477.662,48$ \\
\hline Investimento (capital próprio) (R\$) & $10.125 .000,00$ & $10.223 .900,02$ & $10.321 .377,10$ & & $58.681,97$ & 0,00 \\
\hline Investimento (recursos financiados) (R\$) & $23.625 .000,00$ & 23.428.125,00 & $23.231 .250,00$ & \multirow{3}{*}{$\cdots$} & 0,00 & 0,00 \\
\hline Depesas com Juros (financiamento) (R\$/mês) & 283.500 & 281.138 & 278.775 & & 0 & 0 \\
\hline Fluxo de Caixa do Projeto & 194.162 & 196.525 & 198.887 & & 477.662 & 477.662 \\
\hline \multicolumn{7}{|l|}{ Amortização } \\
\hline Amortização Financiamento ( $\mathrm{R} \$ / \mathrm{mês})$ & $196.875,00$ & $196.875,00$ & $196.875,00$ & \multirow[b]{2}{*}{$\ldots$} & 0,00 & 0,00 \\
\hline Receita Liquida (R\$/mês) & $-2.712,52$ & $-350,02$ & $2.012,48$ & & $477.662,48$ & $477.662,48$ \\
\hline
\end{tabular}

Desta forma o empreendimento pode ser considerado economicamente inviável pois a amortização do capital investido ocorre após 161 meses, tempo considerado longo demais, pois os equipamentos instalados apresentam vida estimada em 15 anos. 


\section{Análise das varáveis econômicas}

Neste capítulo serão apresentadas as conclusões que podem tornar os projetos de cogeração ou de geração térmica viáveis.

\subsection{Sensibilidade ás tarifas de energia}

A viabilidade ou não dos projetos de geração de eletricidade a partir do uso de gás natural é muito sensível à relação existente entre essas duas tarifas.

Para os projetos de cogeração se tornarem viáveis a eletricidade comprada da concessionária deve ser mais cara que a eletricidade gerada a partir do gás natural.

No caso do projeto do exemplo, a eletricidade produzida é $43 \%$ mais cara que aquela comprada da concessionária, considerando apenas as despesas com gás natural, se for utilizado o gás natural comprado da COMGAS em São Paulo, com as tarifas atuais, segundo Resolução CSPE no 124 - Anexo 3 - de $R \$ 0,317422 / m^{3}$, mais $R \$ 0,0279762 / m^{3}$ de margem, que resulta na tarifa de $R \$$ $0,3453982 / \mathrm{m}^{3}$ adotado no projeto, o projeto não é economicamente viável. Considerando as outras despesas, como O\&M, Taxa da ANEEL, Tarifas de transporte, etc. este valor sobe para $58 \%$ mais cara.

Considerando a tarifa de gás natural para térmicas da portaria interministerial ำ 176, de US\$2,57/MMBTU, essa diferença a mais passa para apenas $9 \%$. Mas qual deve ser a relação ideal entre as tarifas, para que os investimentos em geração sejam amortizados? 
Fazendo inúmeras simulações econômicas no exemplo aqui apresentado, foram elaborados os gráficos de sensibilidade tarifária que serão apresentados a seguir.

\section{Com Excedente de Eletricidade}

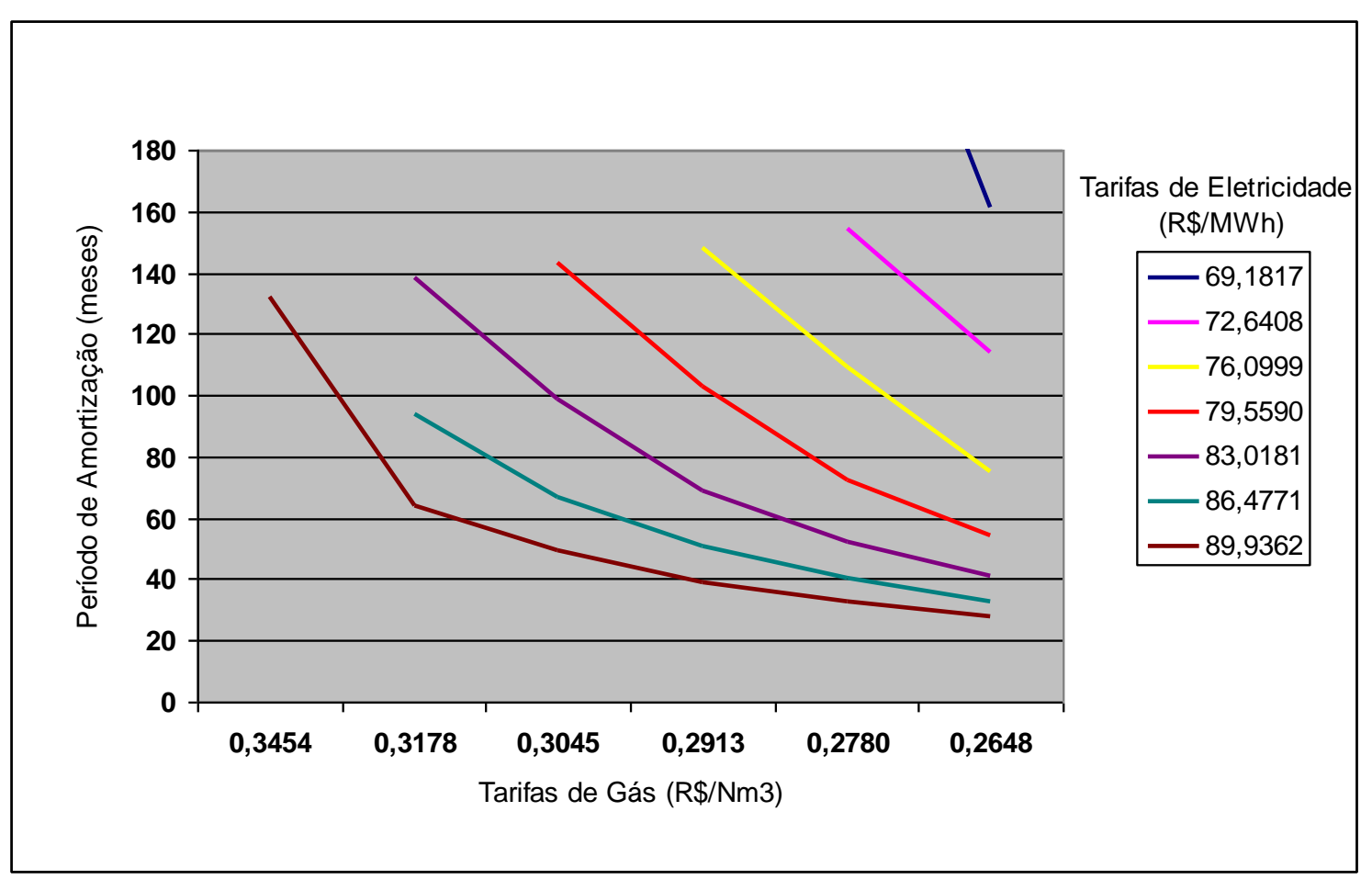

\begin{tabular}{|r|r|r|r|r|r|r|}
\hline $\begin{array}{r}\text { Tarifa de } \\
\text { Eletricidade }\end{array}$ & \multicolumn{7}{|c|}{ Tarifa de gás } \\
\hline & 0,345398 & 0,317756 & 0,304516 & 0,291276 & 0,278036 & 0,264797 \\
\hline 69,1817 & & & & & & 161 \\
\hline 72,6408 & & & & & 154 & 114 \\
\hline 76,0999 & & & & 148 & 109 & 75 \\
\hline 79,5590 & & & 143 & 103 & 72 & 54 \\
\hline 83,0181 & & 138 & 99 & 69 & 52 & 41 \\
\hline 86,4771 & & 94 & 67 & 51 & 40 & 33 \\
\hline 89,9362 & 132 & 64 & 49 & 39 & 33 & 28 \\
\hline
\end{tabular}

Utilizando a tarifa de gás natural variando entre $R \$ 0,3453982 / m^{3}$, e os $R \$$ $0,26497 / \mathrm{m}^{3}$, a tarifa de venda de excedente deve ser igual a $80 \%$ do $\mathrm{VN}$, ou seja, $R \$ 64,05 / M W h$, foram feitas algumas simulações variando a tarifa de 
compra da concessionária, entre a tarifa atual de $\mathrm{R} \$ 69,18 / \mathrm{MWh}$ até $30 \%$ a mais, igual a $\mathrm{R} \$ 89,93 / \mathrm{MWh}$, neste intervalo encontram-se situações de viabilidade econômica para o empreendimento.

Porém do ponto de vista prático é inviável pensar que a eletricidade pudesse ter um aumento real de $30 \%$ para os consumidores industriais do Subgrupo A2.

Por outro lado, se a tarifa atual de gás natural fosse reduzida em 15\% e a tarifa da concessionária aumentar 15\%, o empreendimento começa a ficar economicamente interessante.

Pode se ficar fazendo inúmeras simulações para se tentar chegar ao ponto ótimo da relação entre tarifas, mas após inúmeras mudanças na planilha de cálculos utilizada, chega-se à conclusão que o maior peso na viabilização ou não de qualquer empreendimento de geração de eletricidade, quer em processo de termoelétrica ou de cogeração, são as tarifas de eletricidade e de gás natural.

\section{Sem Excedente de Eletricidade}

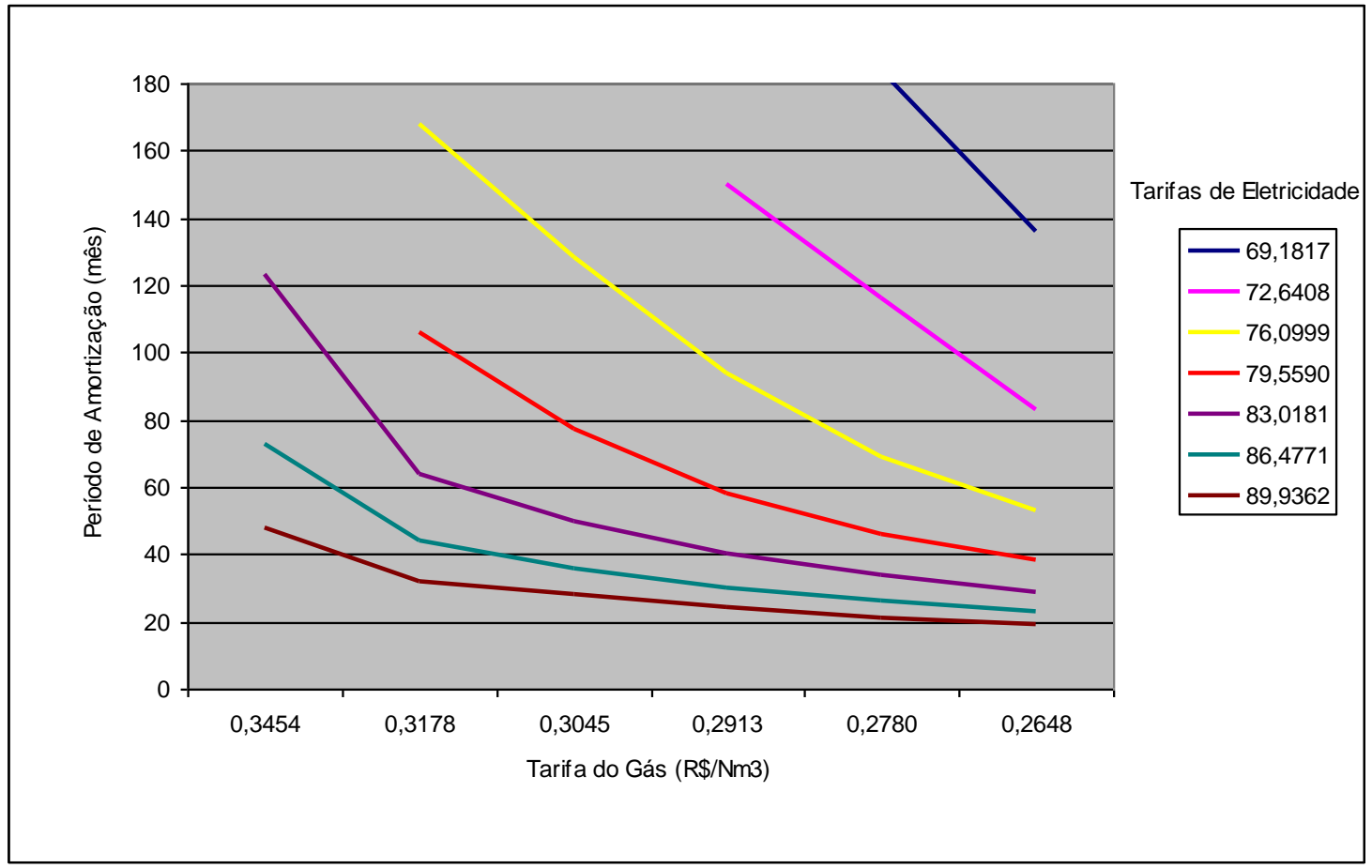




\begin{tabular}{|r|r|r|r|r|r|r|}
\hline Tarifa de & \multicolumn{7}{|c|}{ Tarifa de gás } \\
\cline { 2 - 7 } Eletricidade & 0,345398 & 0,317756 & 0,304516 & 0,291276 & 0,278036 & 0,264797 \\
\hline 69,1817 & & & & & 184 & 136 \\
\hline 72,6408 & & & & 150 & 116 & 83 \\
\hline 76,0999 & & 168 & 128 & 94 & 69 & 53 \\
\hline 79,5590 & & 106 & 77 & 58 & 46 & 38 \\
\hline 83,0181 & 123 & 64 & 50 & 40 & 34 & 29 \\
\hline 86,4771 & 73 & 44 & 36 & 30 & 26 & 23 \\
\hline 89,9362 & 48 & 32 & 28 & 24 & 21 & 19 \\
\hline
\end{tabular}

Utilizando a tarifa de gás natural variando entre $R \$ 0,3453982 / \mathrm{m}^{3}$, e os $R \$$ $0,26497 / \mathrm{m}^{3}$, considerando que a indústria produza eletricidade apenas para uso próprio, foram feitas algumas simulações variando a tarifa de compra da concessionária, entre a tarifa atual de $\mathrm{R} \$ 69,18 / \mathrm{MWh}$ até $30 \%$ a mais, igual a $\mathrm{R} \$$ 89,93/MWh, neste intervalo encontram-se situações de viabilidade econômica para o empreendimento.

\subsection{Sensibilidade à variação cambial}

Existe uma tendência mundial de concentração da fabricação de equipamentos de grande porte e com tecnologia intrínseca em alguns países, no caso das turbinas à gás natural, o Brasil depende da importação de equipamentos.

Os preços desses equipamentos são em (US\$) moeda americana, e assim sendo a variação cambial, ou desvalorização da moeda brasileira influi sensivelmente na viabilização ou não dos projetos de geração termoelétricos, uma vez que as tarifas de energia no Brasil não sofrem diretamente a variação do câmbio, apesar de parte do gás natural disponível para geração de eletricidade ser de origem importada, as tarifas de eletricidade não são correlacionadas ao preço do gás, ou da variação cambial. 
Pode-se notar que houve redução acentuada nas tarifas de eletricidade em US\$ desde a edição do "Plano Real", até hoje. Este fato tem uma influencia negativa muito acentuada na decisão de se implantar novos projetos de geração de eletricidade.

A seguir será apresentado o resultado de simulações dos dois casos apresentados anteriormente, com variação da taxa de câmbio do US\$ para o $\mathrm{R} \$$.

\section{Com excedente de eletricidade}

O gráfico abaixo mostra a influência da variação cambial, (apenas no investimento necessário) no tempo de amortização do projeto, mantendo-se a tarifa de eletricidade a $\mathrm{R} \$ 69,18 / \mathrm{MWh}$ e variando a tarifa do gás natural. $\mathrm{O}$ excedente de eletricidade é comercializado a $\mathrm{R} \$ 64,05 / \mathrm{MWh}$.

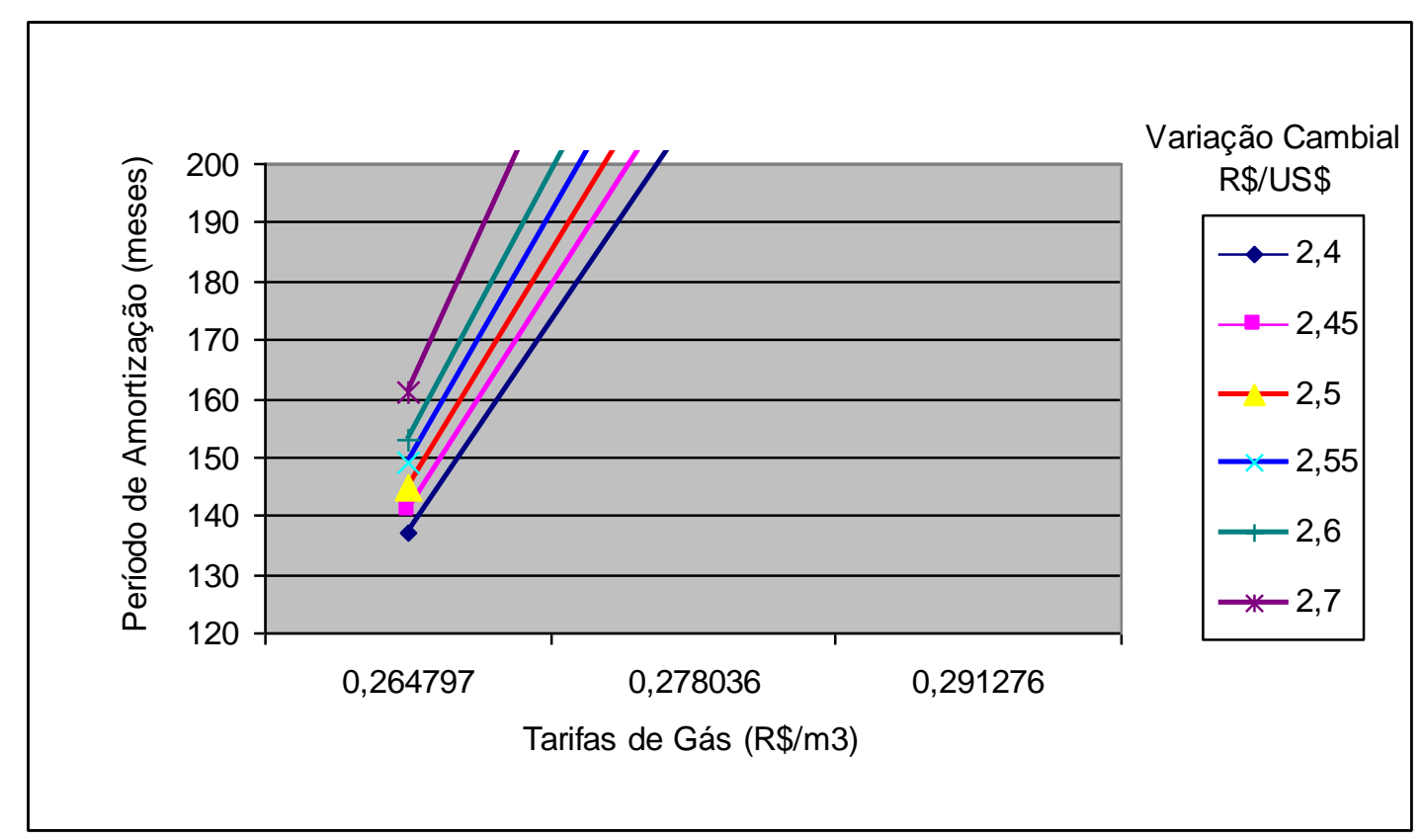




\begin{tabular}{|c|r|r|r|r|r|r|r|}
\hline Tarifas de & \multicolumn{7}{|c|}{ Variaçào Cambial (R\$/US\$) } \\
\cline { 2 - 8 } Gás (R\$) & $\mathbf{2 , 4}$ & $\mathbf{2 , 4 5}$ & $\mathbf{2 , 5}$ & $\mathbf{2 , 5 5}$ & $\mathbf{2 , 6}$ & $\mathbf{2 , 6 5}$ & $\mathbf{2 , 7}$ \\
\hline 0,264797 & 137 & 141 & 145 & 149 & 153 & 157 & 161 \\
\hline 0,278036 & & & & & & & \\
\hline 0,291276 & & & & & & & \\
\hline 0,304516 & & & & & & & \\
\hline
\end{tabular}

\section{Sem excedente de eletricidade}

O gráfico abaixo mostra a influência da variação cambial, (apenas no investimento necessário) no tempo de amortização do projeto, mantendo-se a tarifa de eletricidade a $\mathrm{R} \$ 69,18 / \mathrm{MWh}$ e variando a tarifa do gás natural. Caso sem excedente de eletricidade.

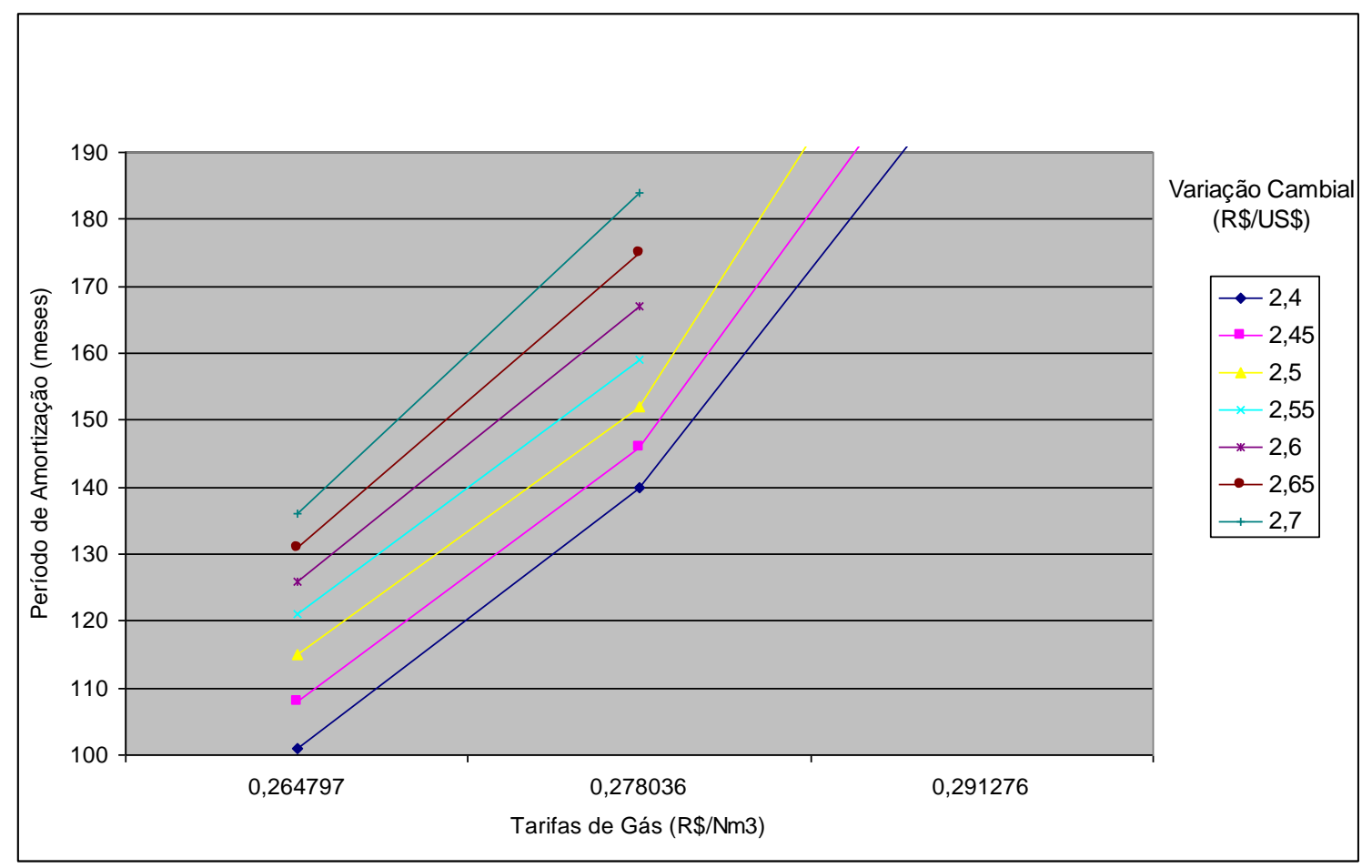




\begin{tabular}{|r|r|r|r|r|r|r|r|r|}
\hline Tarifas de & \multicolumn{7}{|c|}{ Variaçào Cambial (R\$/US\$) } \\
\cline { 2 - 9 } Gás (R\$) & $\mathbf{2 , 4}$ & $\mathbf{2 , 4 5}$ & $\mathbf{2 , 5}$ & $\mathbf{2 , 5 5}$ & $\mathbf{2 , 6}$ & $\mathbf{2 , 6 5}$ & $\mathbf{2 , 7}$ \\
\hline 0,264797 & 101 & 108 & 115 & 121 & 126 & 131 & 136 \\
\hline 0,278036 & 140 & 146 & 152 & 159 & 167 & 175 & 184 \\
\hline 0,291276 & 205 & 216 & 232 & & & & \\
\hline 0,304516 & & & & & & & \\
\hline 0,317756 & & & & & & & \\
\hline 0,345398 & & & & & & & \\
\hline
\end{tabular}

Os gráficos mostram que a variação cambial pode tornar um empreendimento de geração termoelétrico viável ou não economicamente. Nos dois casos apresentados, foi usado o cambio do Dólar americano de $\mathrm{R} \$$ 2,70/US\$, e esse cambio foi reduzido até $\mathrm{R} \$ 2,4 / \mathrm{US} \$$.

Com o cambio a $R \$ 2,4 / U S \$$, o empreendimento sem excedente elétrico passa a ser viável com o gás comercializado a uma tarifa de $R \$ 0,278 / \mathrm{m}^{3}$.

\subsection{Sensibilidade às taxas de juros}

A política de juros adotada pelo país tem uma influencia bastante acentuada nos empreendimento com resultados a longo prazo, como é o caso dos projetos de produção de eletricidade.

Mesmo que o empreendedor utilize seu próprio capital, o dinheiro tem um valor de mercado, e a taxa de interesse para retorno do capital investido é computada nos cálculos de viabilidade econômica de qualquer projeto.

Mesmo com a economia brasileira estabilizada, os juros praticados pelo mercado financeiro são ainda considerados muitos elevado. Se o tomador de capital fizer a captação no mercado a uma taxa de 15\% ao ano, em cinco anos o capital dobrou, e o nosso projeto que é de longo prazo, provavelmente ainda não apresentou retorno do capital inicial mais os juros. 
Será feita uma simulação referente aos exemplos apresentados, variando-se a taxa de juros dos $15 \%$ ao, ano utilizados para captar recursos no mercado financeiro, até os $12 \%$ ao ano, considerados pelo investidor como sua taxa de retorno.

\section{Com excedente de eletricidade}

O gráfico abaixo mostra a influência da variação na taxa de juros no tempo de amortização do projeto, mantendo-se a tarifa de eletricidade a $\mathrm{R} \$$ 69,18/MWh e variando a tarifa do gás natural. O excedente de eletricidade é comercializado a $\mathrm{R} \$ 64,05 / \mathrm{MWh}$.

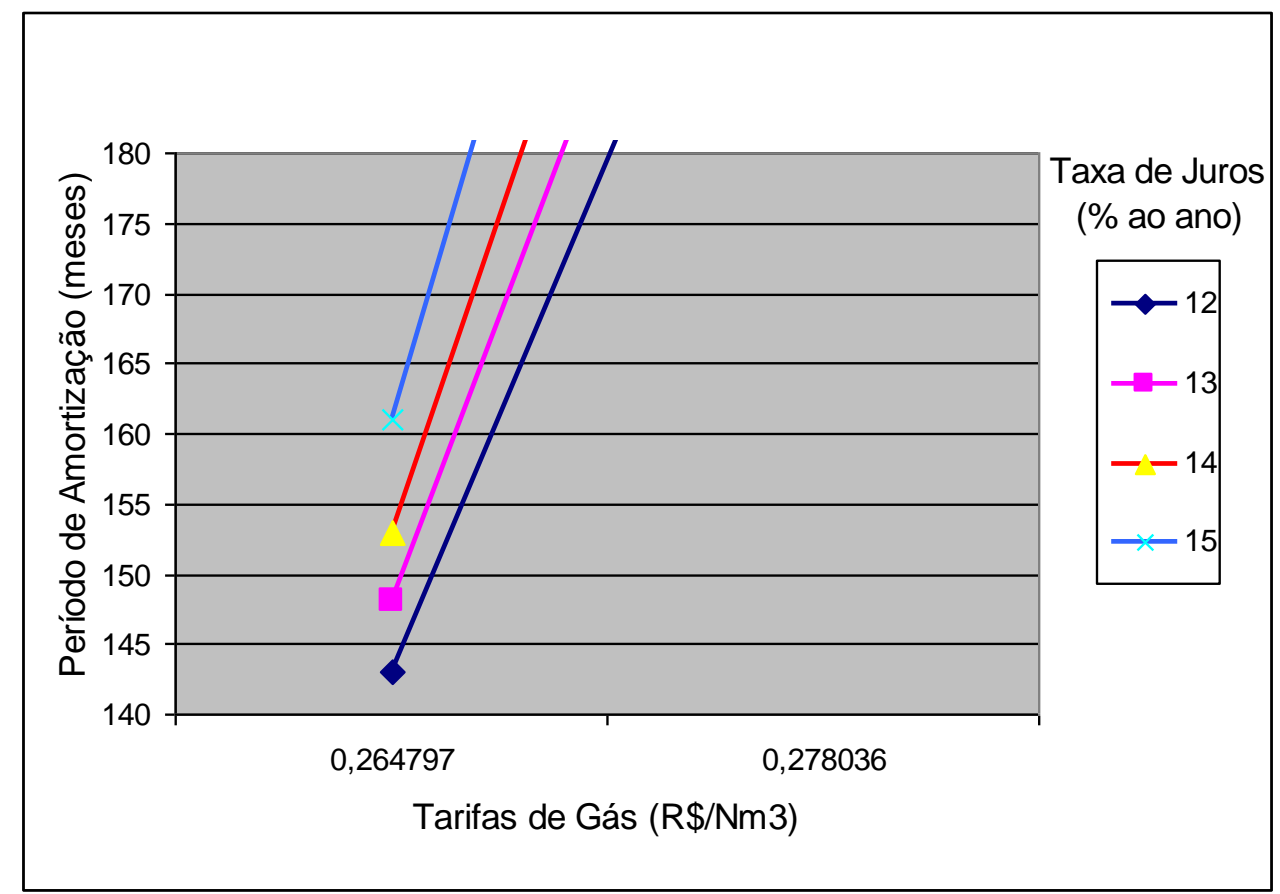

\begin{tabular}{|c|r|r|r|r|}
\hline Tarifas de & \multicolumn{4}{|c|}{ Taxa de Juros (\% ao ano) } \\
\cline { 2 - 5 } Gás (R\$) & $\mathbf{1 2}$ & $\mathbf{1 3}$ & $\mathbf{1 4}$ & $\mathbf{1 5}$ \\
\hline 0,264797 & 143 & 148 & 153 & 161 \\
\hline 0,278036 & & & & \\
\hline 0,291276 & & & & \\
\hline
\end{tabular}




\section{Sem excedente de eletricidade}

O gráfico abaixo mostra a influência da variação variação da taxa de juros no tempo de amortização do projeto, mantendo-se a tarifa de eletricidade a $\mathrm{R} \$ 69,18 / \mathrm{MWh}$ e variando a tarifa do gás natural. Caso sem excedente de eletricidade.

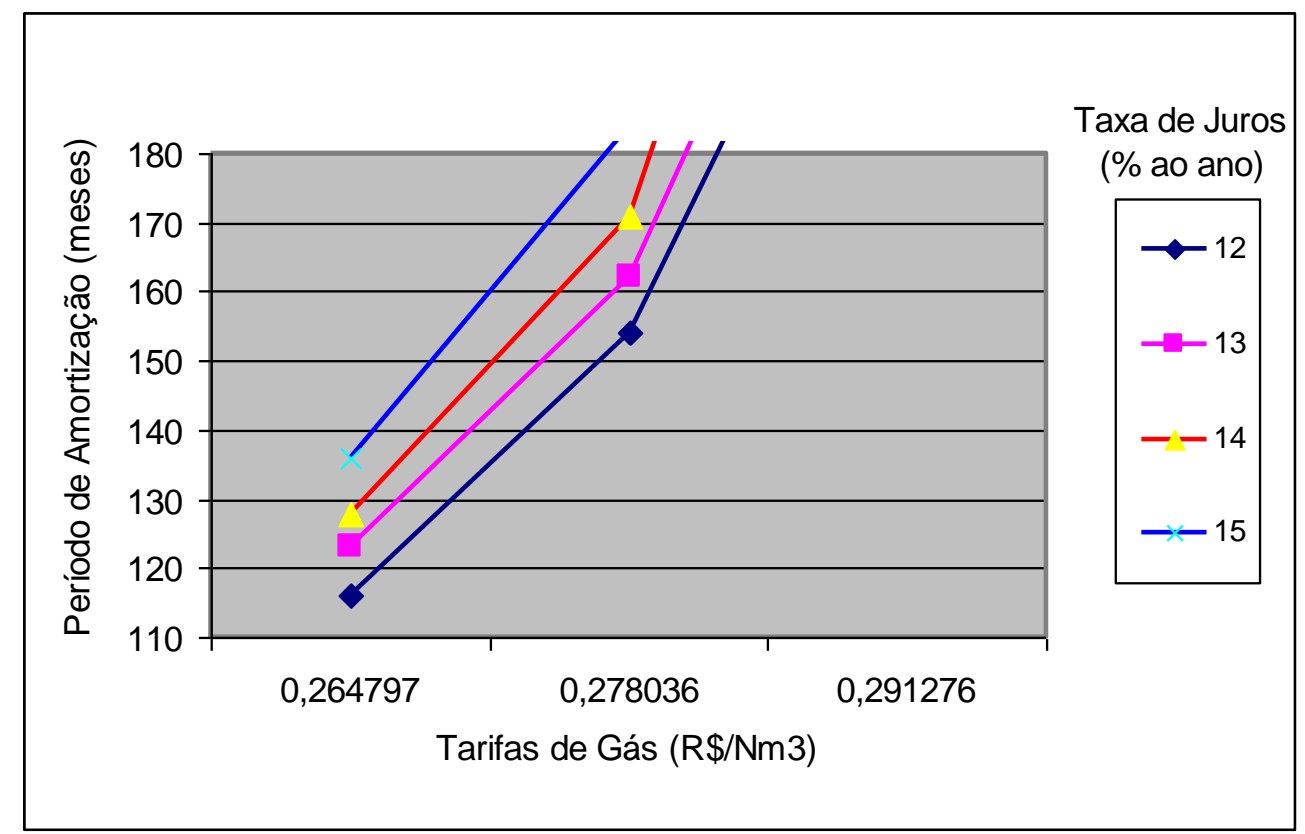

\begin{tabular}{|c|r|r|r|r|}
\hline Tarifas de & \multicolumn{4}{|c|}{ Taxa de Juros (\% ao ano) } \\
\hline Gás (R\$) & $\mathbf{1 2}$ & $\mathbf{1 3}$ & $\mathbf{1 4}$ & $\mathbf{1 5}$ \\
\hline 0,264797 & 116 & 123 & 128 & 136 \\
\hline 0,278036 & 154 & 162 & 171 & \\
\hline 0,291276 & & & & \\
\hline
\end{tabular}

Os gráficos mostram que a variação da taxa de juros pode tornar um empreendimento de geração termoelétrico viável ou não economicamente. 


\subsection{Variando as tarifas de gás e eletricidade}

Cada um dos parâmetros analisados pode não representar grande efeito final, mas quando há sobreposição de interferência dos parâmetros, o efeito causado no resultado da análise econômica será exponencial.

Será feita uma simulação com somatória de efeitos, ou seja, variando as tarifas de energéticos, variando a taxa de correção cambial e a taxa de juros, para se buscar uma situação próxima da ideal, que é aquela que todos os parâmetros envolvidos estejam dentro de limites aceitáveis de modo a tornar os empreendimentos economicamente atrativos.

Será tomado como referência para esta simulação a tarifa atual de gás natural da COMGAS, a tarifa atual de eletricidade da Bandeirante Energia, o Dólar a $\mathrm{R} \$ 2,70 / \mathrm{US} \$$, a taxa de juros do capital a ser investido a $15 \%$ ao ano, a tarifa de eletricidade excedente vendida a $\mathrm{R} \$ 64,05 / \mathrm{MWh}$.

Desta forma montaremos o seguinte cenário:

\begin{tabular}{|l|c|c|c|}
\hline \multicolumn{2}{|l|}{ Valores Atuais } & $\begin{array}{c}\text { Simulação 1 } \\
\text { Venda de } \\
\text { excedentes }\end{array}$ & $\begin{array}{c}\text { Simulação 2 } \\
\text { Sem } \\
\text { excedentes }\end{array}$ \\
\hline Tarifa de gás natural $\left(\mathrm{R} \$ / \mathrm{m}^{3}\right)$ & 0,264761 & 0,264761 & 0,264761 \\
\hline Tarifa de eletricidade $(\mathrm{R} \$ / \mathrm{MWh})$ & 69,18171 & 76,09988 & 76,09988 \\
\hline Dólar $(\mathrm{R} \$)$ & 2,70 & 2,43 & 2,43 \\
\hline Taxa de Juros $(\%$ ao ano) & 15 & 13,5 & 13,5 \\
\hline Tarifa de eletricidade vendida $(\mathrm{R} \$ / \mathrm{MWh})$ & 64,05 & 70,455 & 70,455 \\
\hline
\end{tabular}

O quadro a seguir representa o efeito que ocorreu na "Simulação 1", do exemplo com venda de excedente, onde foi mantida a tarifa do gás natural utilizada para geração termoelétrica, a eletricidade para os consumidores do Subgrupo A2 sofreu um reajuste de $10 \%$, a tarifa de venda da eletricidade 
excedente também foi reajustada em $10 \%$, a taxa de juros anuais e o câmbio do Dólar foram reduzidos em 10\%.

\begin{tabular}{|c|c|c|c|c|c|}
\hline aixa do & s com Tarifa F & 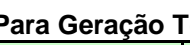 & - & cidade com 1 & \\
\hline Ano & 1 & 2 & 3 & 4 & 5 \\
\hline Consumo Próprio (MWh/ano) & 230040 & 230040 & 230040 & 230040 & 230040 \\
\hline Consumo de Energia Térmica (m3/ano de gá & 33260964 & 33260964 & 33260964 & 33260964 & 33260964 \\
\hline Eletricidade Disponível (MWh/ano) & 103632 & 103632 & 103632 & 103632 & 103632 \\
\hline Receitas de EE Consumo Próprio (custo evita & $17.506 .016,40$ & $17.506 .016,40$ & $17.506 .016,40$ & \begin{tabular}{|l|}
$17.506 .016,40$ \\
\end{tabular} & $17.506 .016,40$ \\
\hline Receita de ET (custo evitado) & $8.806 .206,09$ & $8.806 .206,09$ & $8.806 .206,09$ & $8.806 .206,09$ & $8.806 .206,09$ \\
\hline Receitas das Vendas de EE & $7.301 .392,56$ & $7.301 .392,56$ & $7.301 .392,56$ & $7.301 .392,56$ & $7.301 .392,56$ \\
\hline RECEIT & $33.613 .615,04$ & $33.613 .615,04$ & $33.613 .615,04$ & $33.613 .615,04$ & $33.613 .615,04$ \\
\hline Combus & $22.994 .696,19$ & $22.994 .696,19$ & $22.994 .696,19$ & $22.994 .696,19$ & $22.994 .696,19$ \\
\hline $\mathrm{O} \& \mathrm{M}$ & $2.409 .000,00$ & $2.409 .000,00$ & $2.409 .000,00$ & $2.409 .000,00$ & $2.409 .000,00$ \\
\hline Transmissão & $3.600,00$ & $3.600,00$ & $3.600,00$ & $3.600,00$ & $3.600,00$ \\
\hline Conexão & $74.040,00$ & $74.040,00$ & $74.040,00$ & $74.040,00$ & $74.040,00$ \\
\hline Custo & $25.481 .336,19$ & $25.481 .336,19$ & $25.481 .336,19$ & $25.481 .336,19$ & $25.481 .336,19$ \\
\hline Resu & $8.132 .278,86$ & $8.132 .278,86$ & $8.132 .278,86$ & $8.132 .278,86$ & $8.132 .278,86$ \\
\hline Resul & $7.301 .392,56$ & $7.301 .392,56$ & $7.301 .392,56$ & $7.301 .392,56$ & $7.301 .392,56$ \\
\hline $\mathrm{PIS} / \mathrm{Co}$ & $268.691,25$ & $268.691,25$ & $268.691,25$ & $268.691,25$ & $268.691,25$ \\
\hline Depreciação acelerada (10 anos) & $5.103 .000,00$ & $5.103 .000,00$ & $5.103 .000,00$ & $5.103 .000,00$ & $5.103 .000,00$ \\
\hline 0 antes $(R)$ & $-672.044,94$ & $-385.001,19$ & $-97.957,44$ & $189.086,31$ & $476.130,06$ \\
\hline ANEEL & 52.5 & 52.5 & 52. &, 00 & $52.560,00$ \\
\hline Imposto & $-310.442,94$ & -215.7 & $-120 . c$ & $-336.712,57$ & $-147.263,70$ \\
\hline Resul & $7.811 .027,61$ & $7.811 .027,61$ & $7.811 .027,61$ & $7.811 .027,61$ & $7.811 .027,61$ \\
\hline róprio) & $9.112 .500,00$ & $6.298 .159,89$ & $3.196 .776,03$ & $95.392,16$ & $-3.293 .035,45$ \\
\hline Investimento (recursos financia & $21.262 .500,00$ & $19.136 .250,00$ & $17.010 .000,00$ & \begin{tabular}{|l|}
$14.883 .750,00$ \\
\end{tabular} & $12.757 .500,00$ \\
\hline om Juros (capital pró & 0,00 & 0,00 & 0,00 & 0,00 & 0,00 \\
\hline Depes & $2.870 .437,50$ & $2.583 .393,75$ & $2.296 .350,00$ & $2.009 .306,25$ & $1.722 .262,50$ \\
\hline Fluxo & $4.940 .590,11$ & $5.227 .633,86$ & $5.514 .677,61$ & $5.801 .721,36$ & $6.088 .765,11$ \\
\hline & & & & & \\
\hline Amortização Financiamento & $2.126 .250,00$ & $2.126 .250,00$ & $2.126 .250,00$ & $2.126 .250,00$ & $2.126 .250,00$ \\
\hline RECEITA LIQQUIDA (r\$/ANO) & $2.814 .340,11$ & $3.101 .383,86$ & 3.388.427,61 & $3.675 .471,36$ & $3.962 .515,11$ \\
\hline
\end{tabular}

Obs: Tarifa de venda de excedente de eletricidade $=\mathrm{R} \$ 70,455 / \mathrm{MWh}$

$\begin{array}{lr}\text { TIR } & 39 \% \\ \text { VPL } & 60.533 .459,95\end{array}$

Com estas alterações, o empreendimento, que na situação dos parâmetros atuais não se mostra viável, passa a ser um bom negócio para o investidor, pois a amortização do seu capital acontece aos 48 meses, e o projeto apresenta uma TIR de 39\%, e o VPL de $\mathrm{R} \$ 60.533 .459,95$ nos 15 anos de vida do empreendimento.

O quadro a seguir representa o efeito que ocorreu na "Simulação 2", do caso que não há excedente, onde foi mantida a tarifa do gás natural utilizada para geração termoelétrica, a eletricidade para os consumidores do Subgrupo A2 sofreu um reajuste de $10 \%$, a tarifa de venda da eletricidade excedente 
também foi reajustada em $10 \%$, a taxa de juros anuais e o câmbio do Dólar foram reduzidos em $10 \%$.

Fluxo de Caixa do Projeto Gás com Tarifa Para Geração Térmica e Eletricidade com 10\%

\begin{tabular}{|c|c|c|c|c|}
\hline & 1 & 2 & & 4 \\
\hline Consumo Próprio (MWh/ano) & 326544 & 326544 & 326544 & 326544 \\
\hline Consumo de Energia Térmica (m3/ano de gá & 33260964 & 33260964 & 33260964 & 33260964 \\
\hline Receitas de EE Consumo Próprio (custo evita & $24.849 .959,83$ & $24.849 .959,83$ & $24.849 .959,83$ & $24.849 .959,83$ \\
\hline Receita de ET (custo evitado) & $8.806 .206,09$ & $8.806 .206,09$ & $8.806 .206,09$ & $8.806 .206,09$ \\
\hline RECEITA (R\$/ano) & $33.656 .165,92$ & $33.656 .165,92$ & $33.656 .165,92$ & $33.656 .165,92$ \\
\hline Combustível & $22.994 .696,19$ & $22.994 .696,19$ & $22.994 .696,19$ & $22.994 .696,19$ \\
\hline O\&M & $190.080,00$ & $190.080,00$ & $190.080,00$ & $190.080,00$ \\
\hline Transmissão & $12.960,00$ & $12.960,00$ & $12.960,00$ & $12.960,00$ \\
\hline Eletri. de emergência no MAE (R\$/ano) & $498.960,00$ & $498.960,00$ & $498.960,00$ & $498.960,00$ \\
\hline Custos Operacionais (R\$/ano) & $23.696 .696,19$ & $23.696 .696,19$ & 23.696.696,19 & $23.696 .696,19$ \\
\hline Resultado Operacional & $9.959 .469,73$ & $9.959 .469,73$ & $9.959 .469,73$ & $9.959 .469,73$ \\
\hline ANEEL & $52.560,00$ & $52.560,00$ & $52.560,00$ & $52.560,00$ \\
\hline Resultado (R\$/ano) & $9.906 .909,73$ & $9.906 .909,73$ & $9.906 .909,73$ & $9.906 .909,73$ \\
\hline Investimento (capital próprio) & $9.112 .500,00$ & $4.095 .965,27$ & $-1.196 .981,97$ & $-6.489 .929,20$ \\
\hline Investimento (recursos financiados) & $21.262 .500,00$ & $19.136 .250,00$ & $17.010 .000,00$ & $14.883 .750,00$ \\
\hline Depesas com Juros (financiamento) & $2.764 .125,00$ & $2.487 .712,50$ & $2.211 .300,00$ & $1.934 .887,50$ \\
\hline Fluxo de Caixa do Projeto & $7.142 .784,73$ & $7.419 .197,23$ & $7.695 .609,73$ & $7.972 .022,23$ \\
\hline \multicolumn{5}{|l|}{ Amortização } \\
\hline Amortização Fina & $2.126 .250,00$ & $2.126 .250,00$ & $2.126 .250,00$ & $2.126 .250,00$ \\
\hline RECEITA LÍQUIDA (R\$/ANO) & $5.016 .534,73$ & $5.292 .947,23$ & $5.569 .359,73$ & $5.845 .772,23$ \\
\hline
\end{tabular}

Obs: Tarifa de venda de excedente de eletricidade $=\mathrm{R} \$ 70,455 / \mathrm{MWh}$

TIR $60 \%$

VPL 93.945.333,93

Com estas alterações, o empreendimento, que na situação dos parâmetros atuais não se mostra viável, passa a ser um excelente negócio para o investidor, pois a amortização do seu capital acontece no terceiro ano, e o projeto apresenta uma TIR de 60\%, e o VPL de R\$93.945.333,93 nos 15 anos de vida do empreendimento.

\subsection{Resumo das Simulações}

Poder-se-ia ficar elaborando inúmeras simulações com variação dos diversos parâmetros, individualmente, aos pares, ou todos em conjunto, mas o objetivo 
deste trabalho foi destacar sensibilidade que existe nos empreendimentos para produção de eletricidade através de energia térmica, quer em grandes termoelétricas, quer em projetos de cogeração, médios ou pequenos.

Está mais do que comprovado que a cogeração é uma excelente maneira de produzir eletricidade a partir da energia térmica, competindo e se mostrando melhor que as grandes termoelétricas sob diversos aspectos como:

Técnico: $\quad$-melhor rendimento global;

-melhor distribuição das fontes geradoras;

-menor poluição ambiental;

Econômico: -projetos menores;

-menos intensivo em capital;

-menor custo por KWh gerado.

Seria importante para o País que a cogeração se tornasse uma pratica comum de investimento incorporado aos processos de produção, como ocorre em outros países mais desenvolvidos.

E porque isso não ocorre no Brasil ?

Devido a instabilidade, não apenas econômica, mas política, não é claro para o investidor o vai ocorrer daqui a três meses, que diria daqui a cinco anos, que é o prazo de maturação mínimo dos projetos na área de produção de energia. Como saber se a eletricidade irá se manter nos níveis de preço atual, ou se o gás natural sofrerá grande reajuste pressionado pela desvalorização do Real, ou mesmo se haverá disponibilidade de gás para seu empreendimento. 
O que falta para trazer investimentos na área energética é uma política clara, que garanta, para o investidor que a paridade dos parâmetros aqui demonstrados como essenciais no retorno dos investimentos se mantenham por tempo suficientemente longo.

O quadro atual no Brasil é desfavorável a implantação de qualquer projeto de produção de eletricidade a partir da energia térmica devido a atual correlação dos parâmetros envolvidos.

\subsubsection{Tarifa de gás natural}

As tarifas de gás natural estabelecidas pela CSPE no Estado de São Paulo, podem ser consideradas elevadas em relação às tarifas de eletricidade para os consumidores atendidos em tensão de sub transmissão ou de transmissão (subgrupos A2 e A1).

Em outros estados do Brasil pode-se encontrar o gás natural com tarifas menores.

As tarifas estabelecidas para projetos de geração de eletricidade em situação de emergência podem ser consideradas razoáveis, mas são válidas apenas para projetos implantados até 2.003, e não há garantias de continuidade da aplicação desta tarifa, 


\subsubsection{Tarifa de eletricidade}

As tarifas de eletricidade aplicadas pelas concessionárias, nunca estiveram tão baixas em relação ao Dólar como agora, principalmente para os grandes consumidores, os últimos reajustes aplicados agravaram ainda mais a situação, pois foram menores para os grandes consumidores, e parece que esta tendência deve continuar, pois para diminuir os efeitos do atual racionamento de eletricidade, para as concessionárias, foi anunciado que haverá novo reajuste, apenas para consumidores residenciais. Medidas como esta desestimulam os possíveis investidores.

\section{Conclusões Finais}

Devido a necessidade de expansão do parque de geração de eletricidade, através de energia térmica, no Brasil, para que o País continue crescendo, a principal recomendação deste trabalho, é que os potenciais investidores sejam estimulados pelo governo, através da implantação de um política energética, de longo prazo, nesta direção.

A política energética, e todas as ações decorrentes da implantação desta política deve estar ajustada à política econômica do País, além de se tomar os devidos cuidados na manutenção da paridade dos parâmetros envolvidos em uma geração termoelétrica, como demonstramos nos capítulos anteriores.

A energia é considerada infraestrutura para as atividades econômicas de uma nação, e como tal deve estar consoante com as políticas econômicas desta 
mesma nação, é irracional pensar em crescimento econômico sem planejar o crescimento da infraestrutura.

A "Política Energética Nacional" deve ser interministerial, não pode ter um caráter eminentemente técnico ou puramente econômico, mas uma mistura em boa dose das duas atividades.

Se não houver mudanças na situação atual, que leva a tomada de decisões precipitadas, devido à urgência de soluções, em horizonte não muito distante todos pagarão o preço da implantação de um sistema de produção de eletricidade, através de grandes centrais termoelétricas, sem que antes estejam equalizados os parâmetros econômicos relacionados, incluindo o ajuste tarifário tão necessário no atual momento.

É preciso que se tenha claro os rumos que o País pretende tomar na questão energética.

Se realmente se pretende continuar com esta política de "subsídios" da energia para os grandes consumidores, fazendo com que todos ou outros, médios e pequenos, continuem pagando tarifas elevadas, para que haja o equilíbrio econômico do sistema, é necessário que, ao menos, seja implantado um programa que torne atrativo a esses grandes consumidores (potenciais cogeradores), produzirem sua própria energia, através de sistemas de cogeração. E isto só irá ocorrer se houver retorno econômico dos investimentos. 


\section{Bibliografia}

\section{Referências Bibliográficas}

Balanço Energético Nacional - 2000 - Brasil (português) [1]

PURPA, Public Utility Regulatory Policies Act - 1978 - Estados Unidos (inglês) [2]

Plano Decenal de Expansão - 1999/2008 - Eletrobrás - Rio de Janeiro (português) [3]

Plano - ONS - 2000 (português). [4]

World Energy Council - 1995 - Estados Unidos (inglês)

ANEEL - Agência Nacional de Energia Elétrica - RESOLUÇÃO N o 409 da de 20/10/2000 (Anexo I) - D.O.U. de 23/10/2000 Brasília (português). [6]

CSPE - Comissão de Serviços Públicos de Energia - Portaria 124, de 25 de maio de 2001 - São Paulo (português). [5] 


\section{Bibliografia Recomendada}

Van Wylen, Gordon J. e Sonntag, Richard E. - Fundamentos da Termodinâmica Clássica Brasil (português)

Paula, Cláudio Paiva de - Expansão na oferta de Energia Elétrica - Aspectos Práticos e Metodológicos, Com Ênfase na Opção Termoelétrica (Dissertação de Mestrado) - 1997 - IEE/USP Brasil (português)

Energia, Agência para Aplicação - Relatório do Grupo Cogera - 1997 -Brasil (português)

Júdez, Gaudêncio Zoppetti - Centrales Hidroeléctricas - Barcelona (espanhol)

Néri, Werther - Progettazione e Sviluppo Degli Impianti Chimici - Firenze (italiano)

Gaffert, G. A. - Centrales de Vapor - 1981 - Espanha (espanhol)

GE Power Generation - 39th GE Turbine State of the Art Technology Estados Unidos (inglês)

Kreith, Frank - Princípios da Transmissão de Calor - 1978 - Brasil (português) 
Moraes, José Ermírio de - Manual do Gás Natural - 1986 - Brasil (português)

Silva, Remi Benedito - Manual de Termodinâmica e Transmissão de Calor 1968 Brasil (português)

Verlag, D. Ingo Resch Kous Hndbook - 1997 - Alemanha (inglês) 